\title{
Chemical Approaches for Structure and Function of RNA in Postgenomic Era
}

\author{
Tae Suk Ro-Choi and Yong Chun Choi \\ Departments of Pharmacology and Biochemistry, College of Medicine, Dong-A University, 3-1 Dong Dae Shin Dong, Seo Gu, \\ Busan 602-714, Republic of Korea \\ Correspondence should be addressed to Tae Suk Ro-Choi, tsrochoi37@yahoo.com
}

Received 18 October 2010; Revised 21 June 2011; Accepted 5 July 2011

Academic Editor: Dmitry A. Stetsenko

Copyright ( $\odot 2012$ T. S. Ro-Choi and Y. C. Choi. This is an open access article distributed under the Creative Commons Attribution License, which permits unrestricted use, distribution, and reproduction in any medium, provided the original work is properly cited.

\begin{abstract}
In the study of cellular RNA chemistry, a major thrust of research focused upon sequence determinations for decades. Structures of snRNAs (4.5S RNA I (Alu), U1, U2, U3, U4, U5, and U6) were determined at Baylor College of Medicine, Houston, Tex, in an earlier time of pregenomic era. They show novel modifications including base methylation, sugar methylation, $5^{\prime}$-cap structures (types 0-III) and sequence heterogeneity. This work offered an exciting problem of posttranscriptional modification and underwent numerous significant advances through technological revolutions during pregenomic, genomic, and postgenomic eras. Presently, snRNA research is making progresses involved in enzymology of snRNA modifications, molecular evolution, mechanism of spliceosome assembly, chemical mechanism of intron removal, high-order structure of snRNA in spliceosome, and pathology of splicing. These works are destined to reach final pathway of work "Function and Structure of Spliceosome" in addition to exciting new exploitation of other noncoding RNAs in all aspects of regulatory functions.
\end{abstract}

\section{Introduction}

A key element in the study of cellular RNA metabolism is the molecular characterization of RNA. This characterization requires accurate determination of the RNA sequence. It is imperative to understand how RNA structure complements the functional definition of RNA. Cellular RNAs are posttranscriptionally modified at various points in the primary RNA transcript as well as processed. In cellular RNA metabolisms, RNA maturation is performed through various structural alterations that include chemical modifications of constituent components. A most representative modification is observed in chain shortening, rearrangements by transfer of phosphodiester linkages involved in splicing mechanisms (pre-mRNA), deletions (pre-rRNA), and transsplicing (trypanosomal mRNA). Another is chain expansion demonstrated by modifications observed on polyadenylation, Uaddition at $3^{\prime}$ ends, $5^{\prime}$-cap formation at $5^{\prime}$ ends, and insertions within trypanosome RNA. Other examples of modifications are base modifications, such as deaminations, methylations, hypermodifications, and ribose methylations.
The most modified RNAs are tRNAs containing approximately 2-22 modified nucleotides per molecule of $\sim 75$ nucleotide length, and there have been more than 130 different signature modified nucleotides reported [1]. The discovery of snRNA and $m_{3}{ }^{2.2 .7} \mathrm{G}$ caps occurred within the last 50 years. They also contain their own specific modified nucleotides such as $\Psi, \mathrm{m}^{6} \mathrm{~A}, \mathrm{~m}^{2} \mathrm{G}$, and $2^{\prime}$-O-methylated nucleotides (Table 1).

The next class is the ribosomal RNAs which contain 204-209 modified nucleotides within $18 \mathrm{~S}(1,869 \mathrm{nt})+28 \mathrm{~S}$ $(5,035 \mathrm{nt}) \mathrm{RNA}$ in eukaryotes. The mRNAs contain the least modified nucleotides, with the exception of the $5^{\prime}$ end cap structure and occasional $\mathrm{m}^{6} \mathrm{~A}$ in the molecule.

In ensuing years, massive scale DNA sequencing was advanced to accommodate the "Human Genome Project." Two groups published the genomic map where the coding genes were cataloged. It was conservatively estimated that there are 25,000 genes and 50,000 proteomes involved in cell metabolism. It was also envisioned that processing mechanisms could be discerned by comparing the genomic structure with the RNA sequence determined using cDNA methods. Based 
TABle 1: Signature sequences and modifications of major snRNAs. The $5^{\prime}$ cap and $3^{\prime}$ nucleosides, base modified nucleosides, and alkali resistant oligonucleotides were determined by many methods described in the text. The table provides a summary of individual RNA characteristics of rat Novikoff hepatoma cells.

\begin{tabular}{|c|c|c|c|c|c|}
\hline RNA & Subspecies & Localization & $5^{\prime}$ End & $3^{\prime}$ End & Modified Nucleotides \\
\hline \multirow{3}{*}{ 4.5S RNA } & I & Extranucleolar nuclei & pppG & $\mathrm{U}-\mathrm{OH}$ & \\
\hline & II (U6) & Extranucleolar nuclei & mpppG & $\mathrm{U}-\mathrm{OH}$ & $\begin{array}{l}3 \Psi, \mathrm{m}^{6} \mathrm{~A}, \mathrm{~m}^{2} \mathrm{G}, \mathrm{AmA} \\
\mathrm{AmG}, \mathrm{AmGmC} \\
\mathrm{CmC}, \mathrm{CmA}, \mathrm{CmCmU}\end{array}$ \\
\hline & III & Extranucleolar nuclei & $\mathrm{pA}$ & Um & $\begin{array}{l}\text { AmA, GmA, } 2 \mathrm{GmG} \\
\mathrm{m}^{2} \mathrm{G}, \mathrm{m}^{6} \mathrm{~A}, 3 \Psi\end{array}$ \\
\hline \multirow{3}{*}{ 5S RNA } & I & $\begin{array}{l}\text { Nucleoli, nuclei and } \\
\text { cytoplasm }\end{array}$ & pppG & $\mathrm{U}-\mathrm{OH}$ & \\
\hline & II & $\begin{array}{l}\text { Nucleoli, nuclei and } \\
\text { cytoplasm }\end{array}$ & pppG & $\mathrm{U}-\mathrm{OH}$ & \\
\hline & III (U5) & Extranucleolar nuclei & $\mathrm{m}_{3}{ }^{2,2,7}$ GpppAmUmAC & $\begin{array}{l}\mathrm{U}-\mathrm{OH} \\
\mathrm{A}-\mathrm{OH}\end{array}$ & $\mathrm{UmU}, \mathrm{GmC}, 2 \Psi$ \\
\hline \multirow[t]{2}{*}{ U1 RNA } & U1a (5.8S RNA) & $\begin{array}{l}\text { Nucleoli and } \\
\text { cytoplasm }\end{array}$ & $\mathrm{pC}, \mathrm{pG}$ & $\mathrm{U}-\mathrm{OH}$ & $\mathrm{UmG}, \mathrm{GmC}, \Psi$ \\
\hline & U1b, U1c & Extranucleolar nuclei & $\mathrm{m}_{3}^{2,2,7} \mathrm{GpppAmUmAC}$ & $\begin{array}{l}\mathrm{U}-\mathrm{OH} \\
\mathrm{G}-\mathrm{OH}\end{array}$ & $\mathrm{AmC}, 2 \Psi$ \\
\hline U2 RNA & & Extranucleolar nuclei & $\mathrm{m}_{3}^{2,2,7} \mathrm{GpppAmUmC}$ & $\begin{array}{l}\mathrm{C}-\mathrm{OH} \\
\mathrm{A}-\mathrm{OH}\end{array}$ & $\begin{array}{l}\text { GmGmC, GmG, } \\
\text { GmA, m }{ }^{6} \mathrm{AmG}, \\
\mathrm{Cm} \Psi, \mathrm{UmA}^{6} \mathrm{CmU}, \\
13 \Psi,\left(\mathrm{m}^{6} \mathrm{~A}, \mathrm{~m}^{2} \mathrm{G}\right)\end{array}$ \\
\hline U3 RNA & $\begin{array}{l}\mathrm{U} 3 \mathrm{a}, \mathrm{U} 3 \mathrm{~b} \\
\mathrm{U} 3 \mathrm{c}, \mathrm{U} 3 \mathrm{~d}\end{array}$ & Nucleoli & $\mathrm{m}_{3}{ }^{2,2,7} \operatorname{GpppAmA}(\mathrm{m}) \mathrm{AG}$ & $\begin{array}{l}\mathrm{A}-\mathrm{OH} \\
\mathrm{U}-\mathrm{OH} \\
\mathrm{C}-\mathrm{OH}\end{array}$ & $2 \Psi$ \\
\hline
\end{tabular}

on the ever-increasing number of RNA sequences, it was determined that most coding RNAs mature as a result of alternative splicing. Aberrant splicing is attributed to point mutations in the genetic code and splicing code [2]. It is noted that RNA sequencing can aid the determination of the molecular pathogenesis of diseases.

\section{Historical Venture of RNA Research}

Detailed nucleic acid chemistry began with discoveries of the DNA helix by Watson and Crick [3] and DNA polymerase by Lehman et al. $[4,5]$. With DNA being the genetic material providing a blue print for living creatures, it moved genomic era thinking away from the earlier notion that protein, carbohydrate, and lipid were the only essences of living things.

DNA is there to provide information needed to build the cells, tissues, organs, and whole individuals. It took a long time to move from the histochemical presentation of DNA in the nucleus and RNA in the nucleolus and cytoplasm [14] to the isolation of nucleoli, nuclei, mitochondria and ribosomes, facilitating the elucidation of their components, their structures, and their functions. Even within the same species, no two individuals are identical. Disarray in DNA structure can determine whether one is healthy or diseased. In the quest to conquer cancer, differences in cellular morphology and uncontrolled growth became and remain a major research consideration when one compares normal cells with cancerous cells and tissues. Cancer cells with pleo- morphic, hypertrophic nuclear, and nucleolar morphology remain a useful pathological criterion for a cancer diagnosis. The information within genes is transferred to RNA and then to proteins made on ribosomes that define a cell phenotype. The fractionation of cells into various components includes nucleoli, nuclei (Figure 1), ribosomes, mitochondria, cytosol and others.

The main interest among these compartmental components was the RNA. The RNA has its own exclusive properties which are not found in DNA.

The discovery of RNA polymerase I in the nucleoli [31] is the landmark of RNA research in these cellular compartments. It was not until 1968, with the introduction of gel electrophoresis into RNA research [32], that subspecies of 4-8S RNAs could be separated from high-molecularweight RNAs (>18S RNA). Until then, the 4-8S RNAs were considered as tRNAs and their precursors. Different from the prokaryotic cells, eukaryotic cells were shown to have a variety of small RNAs in their nuclei (Figure 2 ). These RNAs used to be called LMWN RNA (low-molecular weight nuclear RNA) and now the name is unified as snRNA (small nuclear RNA).

These include U1 RNA, U2 RNA, U3 RNA, (named as such because these RNAs contain a high proportion of uridylic acid), 5S RNA III (U5 RNA), 4.5S RNA I (Alu RNA), 4.5S RNA II (U6), and 4.5S RNA III. All of these snRNA species and many more have been sequenced and their functions elucidated in pre-rRNA processing [33] and pre-mRNA splicing $[34,35]$. 
Nuclear and nucleolar morphology
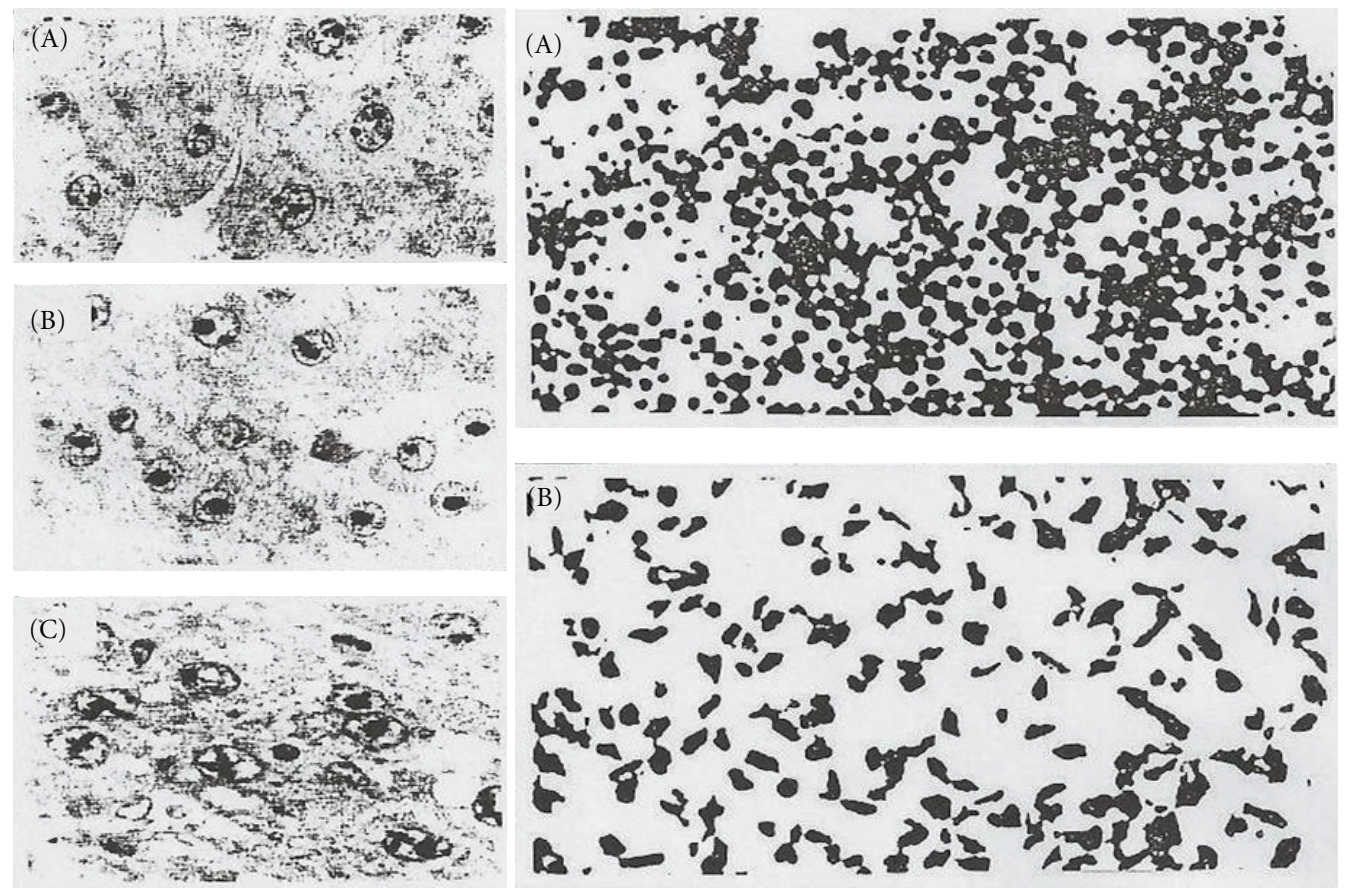

Rat liver nuclear morphology

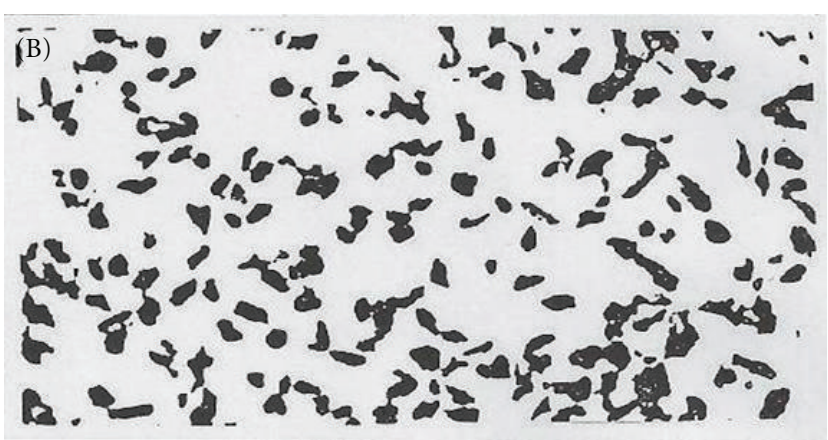

(A) Normal liver

(A) Normal rat liver nucleoli

(B) Regenerating liver

(B) Walker 256 carcinoma nucleoli

(C) Hepatocellular carcinoma

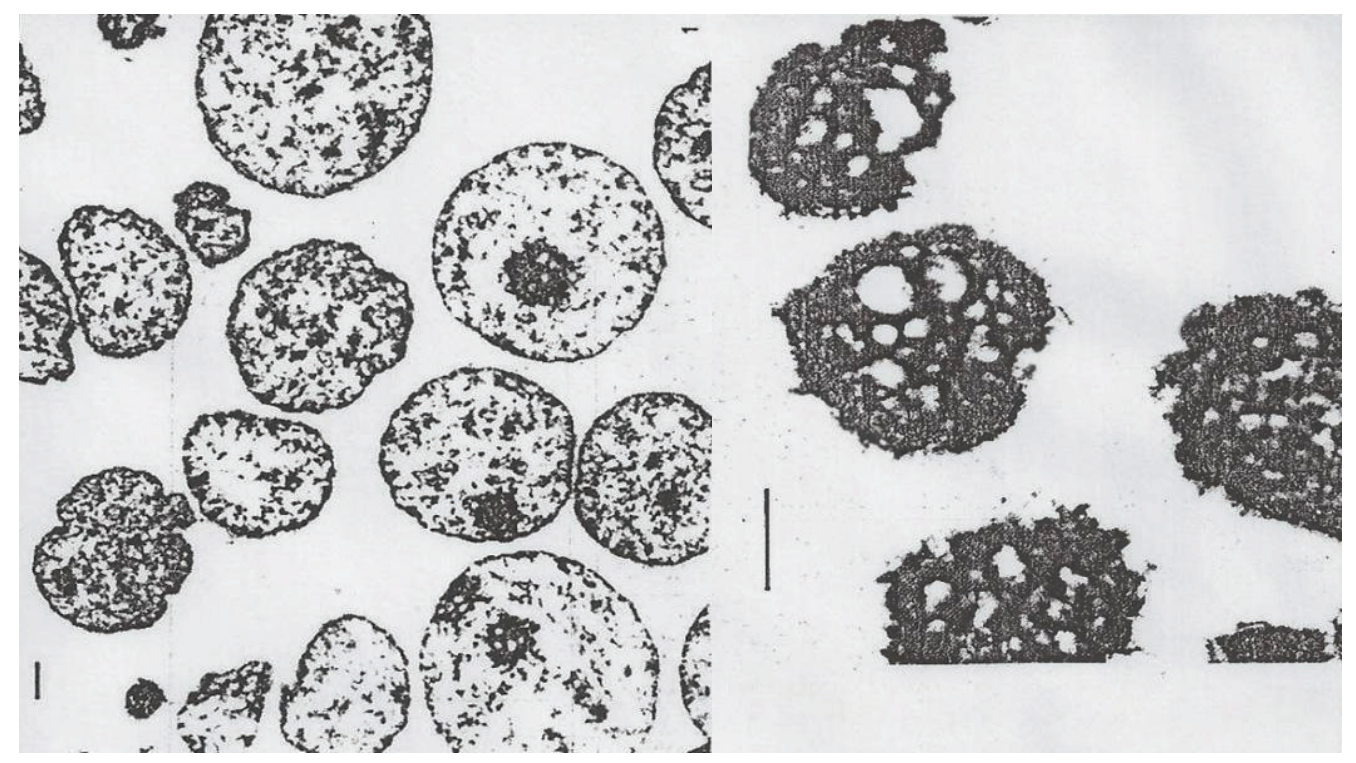

EM picture of isolated rat liver nuclei

EM picture of isolated rat liver nucleoli

Figure 1: Nuclear and nucleolar morphology. Normal rat liver nuclei have 1-6 round nucleoli which are less than $2 \mu \mathrm{m}$ in diameter. In regenerating liver, cells contain enlarged nucleoli. In tumor cells (hepatocellular carcinoma), the nucleoli are not only enlarged but also they become pleomorphic in morphology. Nuclei were isolated by homogenization in $2.3-2.4 \mathrm{M}$ sucrose containing $3.3 \mathrm{mM} \mathrm{CaCl}_{2}$. Nuclei were sonicated in $0.34 \mathrm{M}$ sucrose and layered on $0.88 \mathrm{M}$ sucrose for purification by centrifugation. Isolated nuclei and nucleoli had high purity, and morphologies were well preserved [6]. 


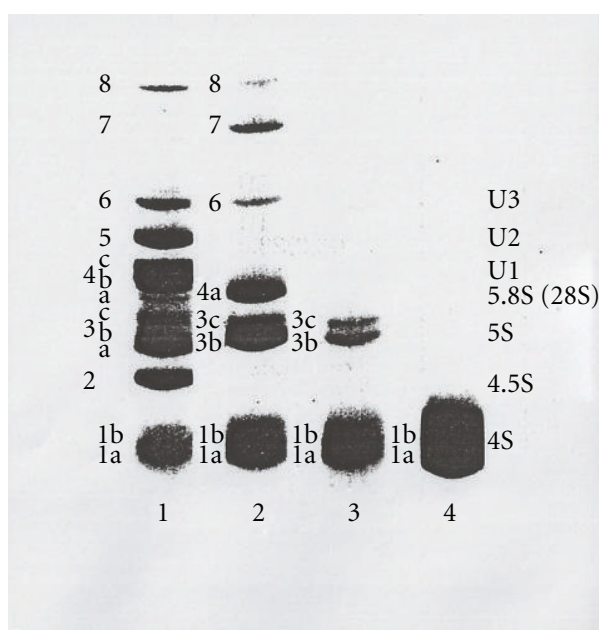

(a)

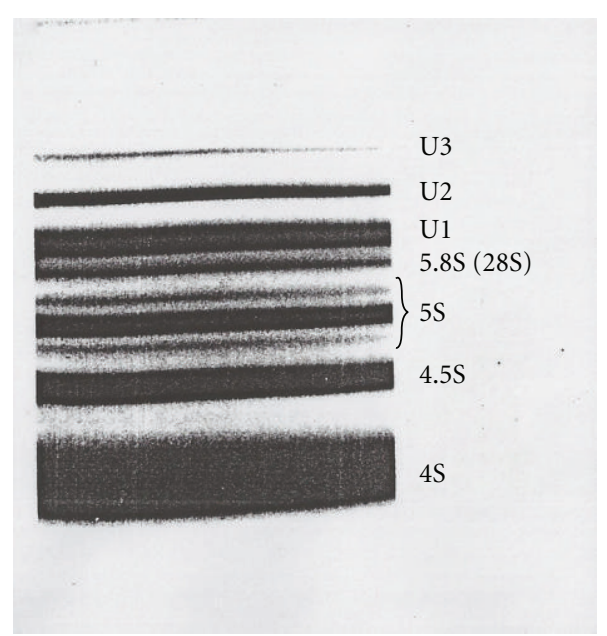

(b)

FIgure 2: Polyacrylamide gel electrophoretic separations of nuclear 4-7S RNAs of rat liver and Novikoff hepatoma cells [7]. (a) The 8\% gel electrophoretic patterns of 4-7S RNA from various cell organelles of rat liver. The gel was stained with methylene blue for RNA visualization. (1) Nuclear 4-7S RNA, (2) ribosomal 4-7S RNA, (3) mitochondrial 4-7S RNA, and (4) soluble cytoplasmic sap 4-7S RNA. (b) The 10\% slab polyacrylamide gel electrophoretic separation of [ $\left.{ }^{32} \mathrm{P}\right]$-labeled 4-7S RNA from Novikoff hepatoma cell nuclei. The gel was autographed with X-ray film.

TABLE 2: Characteristics of RRM/RNP/RBD domain.

(1) 90-100 amino acids domain and most abundant in vertebrates

(2) Many RNA binding proteins contain more than one RRM

(3) Contain 2 conserved RNP1 (RGQAFVIF in $\beta 3$ ) and RNP2 (TIYINNL in $\beta 1$ ) in 4 antiparallel $\beta$-sheets of $\beta \alpha \beta \beta \alpha \beta$-fold

(4) Binds 2-8 nucleotides of RNA (2 in CBP20, nucleolin and 8 in U2B")

(5) A typical RRM containing 4 nucleotide binding sites (UCAC)

(6) 3 conserved aromatic amino acids (Y, F, W, H or P) in central $\beta$-strands ( 2 in RNP1 of $\beta 3$ and 1 in RNP 2 in $\beta 1$ )

(7) 2 RRMs in a protein are separated by small linker and provide a large RNA binding surface or RNA binding surface point away from each other

(8) RNA bases are usually spread on the surface of protein domains while the RNA phosphates point away toward the solvent

(9) Binding surface of the protein is primarily hydrophobic in order to maximize intermolecular contact with the bases of the RNA

(10) Few intramolecular RNA stacking and many intermolecular stacking mediated by aromatic amino acids

RNA recognition is a two-step process, in which any RNA is attracted approximately equally well. However, if stacking and

(11) hydrogen-bond interactions that "lock" the interaction cannot be properly established, the complex redissociates quickly (large $\left.k_{\text {off }}\right)$, which results in overall weak affinity for RNA oligonucleotides of the wrong sequence

Many ssRNA binding proteins recognize RNA in the loop (stem-loop) better than in ssRNA ( $k_{\text {on }} \sim 3$ fold $\& k_{\text {off }} \sim 590$ fold, therefore, overall affinity $\sim 2000$ fold differences) due to higher entropy loss with ssRNA binding than stem-loop binding and stabilizing interactions of stem

The most interesting discoveries in the midst of sequencing were the very unusual trimethylguanosine cap structure in U1 RNA $\left(\mathrm{m}_{3}{ }^{2,2,7} \mathrm{GpppAmUmAC}\right)$, U2 RNA $\left(\mathrm{m}_{3}{ }^{2,2,7} \mathrm{GpppAmUmC}\right)$, U3 RNA $\left(\mathrm{m}_{3}{ }^{2,2,7} \mathrm{GpppAmA}(\mathrm{m})\right.$ AGC), and 5S RNA III (U5 RNA) ( $m_{3}^{2,2,7}$ GpppAmUmAC) [36]. Afterwards, myriads of cap structures in viral RNA and mRNA were discovered [37].

The history of RNA sequence work has occurred in three eras. The pregenomic era was devoted to the small RNAs and commenced with the sequence of large RNAs as technology developed for cDNA synthesis, amplification, cloning, and sequencing. The DNA technology was explosive and paved the way toward establishment of sequence technology not only for RNA and cDNA but also for genomic DNA.

In addition to sequence study, the secondary and tertiary structures have also been determined. A representative study was the crystallographic study of RNA-protein interactions. For example, the most well-worked-out motif is RRM (RNA recognition motif) which is most abundant in hnRNP [40] and splicing factors [41]. The summary of characteristics of RRM is in Table 2.

It has been known for a long time that pre-mRNA (hnRNA) is cotranscriptionally assembled into beads on a string consisting of 30-50S (20-30 nm) particles [42]. The 


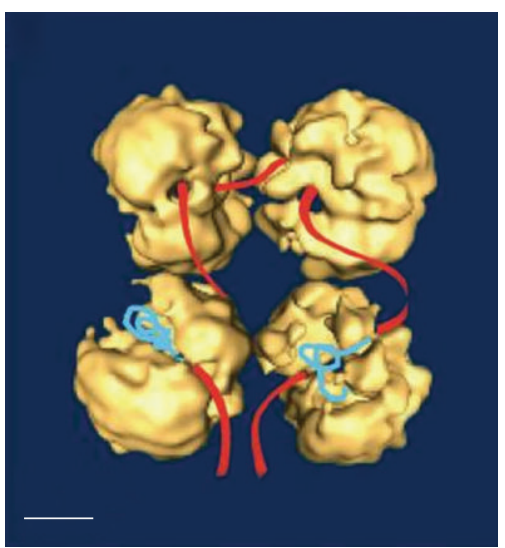

- Exon

- Intron

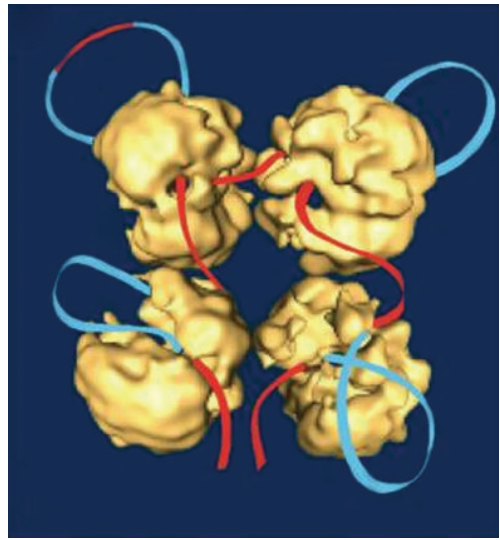

- Exon

- Intron

(a)

(b)

FIGURE 3: The supraspliceosome model from the article by Sperling et al. [8]. (a) It was stated that pre-mRNA which is not being processed is folded and protected within the native spliceosome. (b) With different staining protocol, it was possible to visualize the RNA strands and loops emanating from the supraspliceosome. These complexes were found to contain hnRNP proteins (personal communication).

RNP (hnRNP) has usually 48 hnRNP proteins and $\sim 700$ 800 nucleotide long RNA string [43]. More recently, most hnRNP proteins have been found to have 1-2 RRM motifs for RNA binding. From these characteristics, the primary RNA transcripts have been folded from the $5^{\prime}$ end with the following rules: a minimum of 3 nucleotides in the loop and a minimum of 3 base pairs at the stem. According to stacking and loop energy rules, two nucleotide loops cannot exist. The number of base pairs needed for stabilization with the most stable stacking energies by CCC/GGG or GGG/CCC is 3 base pairs with $-9.8 \mathrm{kcal}$ and the highest loop destabilizing energy is $+8.4 \mathrm{kcal}$ [44]. In addition, protein binding to RNA has been shown to have $-\triangle \mathrm{G} \approx 10-13 \mathrm{Kcal} / \mathrm{mol}$ [45] which can overcome the loop destabilizing energies of any size. With this rule, folding the hnRNA in GC, AU, and GU pairings was carried out as the RNA was transcribed, extending contiguous base pairing until it comes to a base pair mismatches. Accordingly, small simple RNA hairpins have been constructed with the aid of a computer [46] from the $5^{\prime}$ end (transcription start sites). Consensus patterns for folding characteristics have been observed (Table 3 ).

The transcripts form one stem loop for every 15-18 nucleotides which is consistent with $\sim 15-17$ nucleotides per hnRNP protein (700-800 nucleotides per 48 hnRNPs in one hnRNP particle) reported earlier [43]. The thermodynamics of RNA folding was consistent with the order of splicing in ovomucoid pre-mRNA [47]. From the point of view that supraspliceosomes contain hnRNP proteins (personal communication), it may be that this cotranscriptional formation of hnRNP string particles [47-49] may contribute to a role in the formation of supraspliceosomal RNP (Figure 3 ) [8].

The postgenomic era is the present day era or the second generation genome era. With the recent discovery that there
TABLe 3: Frequency of stem loops in primary pre-mRNA transcripts. The simple stem loops with minimal 3 nucleotides in the loop and minimal 3 base pairs in the stem consisting of AU, GC, and GU pairs have been constructed with the aid of a computer [46]. The total number of nucleotides were divided by numbers of stem loops for frequency. The number of nucleotides in each loop and each stem and spacer were counted and averages were calculated. (1) Human insulin gene transcript: 1,430 nt. (2) Human HDHGT (25-hydroxyvitamin D3 1- $\alpha$-hydroxylase gene transcript): 4,825 nt. (3) Human FMR1 (fragile mental retardation 1) gene transcript: 39,224 nt. (4) Chicken ovomucoid gene transcript: 6,067 nt.

\begin{tabular}{lcccc}
\hline Transcript & nt/loop & nt/stem & $\begin{array}{c}\text { nt in } \\
\text { spacer }\end{array}$ & Frequency \\
\hline (1) Insulin & 4.6 & 7.4 & 3.5 & 15.5 \\
(2) HDHGT & 5.8 & 7.0 & 4.9 & 17.6 \\
(3) FMR1 & 5.0 & 6.8 & 3.4 & 15.3 \\
(4) Ovomucoid & 5.6 & 7.0 & 3.7 & 16.0 \\
\hline
\end{tabular}

is a paradox $[50,51]$ in the cellular transcript number, which is 2-3-fold in excess and that $50 \%$ of the cellular transcripts are ncRNAs, the second generation genomic era is in the process of resequencing the genome for ncRNAs. It is anticipated that there will be a revision in the first generation genomic picture. In this era, work is proceeding that will probe and dissect the RNA metabolism in which aberrant processing should be elucidated by RNA sequencing. To dissect the molecular pathology of RNA metabolism, it is also necessary to study higher-order structures based on the sequence studies involved in the assembly of macromolecular machinery. It is natural to hope that therapeutic interventions will be discovered that can correct errors in the genetic code and its product splicing. 
TABle 4: Paradoxical characteristics of ncRNAs in humans and mice [50, 51]. The excessive number of transcripts than anticipated for 25,000 genes indicates that the ncRNAs which were not detected due to scarce abundance have been detected by more sensitive methods. Some of these characteristics are summarized.

\begin{tabular}{|c|c|c|}
\hline & Human & Mouse \\
\hline Gene Number & $75,000,84,000$ or 140,000 (cDNA identified) & \\
\hline Transcripts & & 181,000 \\
\hline Population & $50 \%$ Poly-A RNAs (of 16\% genome) & $\begin{array}{l}\quad 50 \% \text { transcripts } \\
\quad \text { (of } 62 \% \text { genome }) \\
(35 \% \text { from antisense strand) }\end{array}$ \\
\hline Intron & $30 \%$ genome & \\
\hline Processing & \multicolumn{2}{|c|}{ Polyadenylation, $5^{\prime}$ cap, splicing, nucleotide modification } \\
\hline Transcripts from & \multicolumn{2}{|c|}{ Intergenic, Intronic regions and antisense strand } \\
\hline Short ncRNAs & \multicolumn{2}{|c|}{$\begin{array}{c}\text { miRNA, siRNA (tasiRNA, natsiRNA), piRNA, rasiRNA (pitRNA), PARs (PROMTs, } \\
\text { PASRs, TSSa-RNAs, tiRNAs), MSY-RNA, snoRNA, sdRNA, moRNA, tel-sRNA, } \\
\text { crasiRNA, hsRNA, scaRNAs, AluRNA, YRNA, tRNA-derived RNAs }\end{array}$} \\
\hline $\begin{array}{l}\text { Long ncRNA (lncRNA) } \\
(0.5-100 \mathrm{~kb})\end{array}$ & \multicolumn{2}{|c|}{$\begin{array}{c}\text { Cancers, disorders in skin, heart, brain, cerebellum, and so forth. TR/TERC, NEAT } \\
\text { RNA (NEAT1v-1, NEAT1v-2, NEAT2/MALAT1), PINC RNA, DD3/PCA3, } \\
\text { PCGEM1, SPRY4-1T1, xiRNAs (Xist RNA, Tsix RNA, RepA RNA), AIR, H19, } \\
\text { KCNQ1ot1, HOTAIR, BORG, CTN RNA, ANRIL RNA, LINE, CSR RNA, satellite } \\
\text { DNA transcripts and so forth }\end{array}$} \\
\hline Function & Regulatory function in all aspe & $n[52]$ \\
\hline
\end{tabular}

The RNAs have been classified according to the following diverse basis of criteria:

(i) cell biology: cell types, subcellular origins,

(ii) molecular weight: high molecular weight (HMW) and low molecular weight (LMW/small),

(iii) S value: $5 \mathrm{~S}$ rRNA, 7S RNA, 18S RNA, and others,

(iv) linearity: linear, cyclized, and branched (Y shaped),

(v) metabolism: precursor, processed intermediates, and mature,

(vi) standard: hnRNA, rRNA, mRNA, tRNA, and ncRNA (snRNA, snoRNA, miRNA, and others as in Table 4).

\section{Preparation of RNA from Isolated Subcellular Compartments}

RNA can be extracted from purified nucleoli, nuclei, ribosomes, mitochondria, and cytosol by the SDS-phenol procedure. The procedure involves the suspension of organelles in $0.3-0.5 \%$ SDS (sodium dodecyl sulfate), $0.14 \mathrm{M} \mathrm{NaCl}$, and $0.05 \mathrm{M}$ sodium acetate buffer at $\mathrm{pH} 5.0$ and deproteinization by phenol containing $0.1 \%$ 8-hydroxyquinoline at $65^{\circ} \mathrm{C}$ [53]. The extracted RNA is precipitated with $2-2.5$ volumes of ethanol containing $2 \%$ potassium acetate. The RNA is washed by ethanol and dissolved in appropriate buffer for the analysis. The DNA and protein contaminations are less than $3 \%$ by weight. The purified RNA is separated into individual RNA species using sucrose density gradient centrifugation, gel electrophoresis, and column chromatography [38].

\section{Structure Determination}

4.1. Structural Characteristics of Various RNAs Bearing Signature Sequences and Modifications. The RNA is composed of basic 4 nucleosides of guanosine, adenosine, uridine, and cytidine linked by $5^{\prime}-3^{\prime}$ phosphodiester bonds between two ribose moieties. In addition, some of these nucleotides are modified in base as well as in ribose moieties and contain unusual pyrophosphate bonds at their $5^{\prime}$ ends and $2^{\prime} \mathrm{O}$ methylated $3^{\prime}$ end.

Mature RNAs are synthesized in the nuclei and directed by the posttranscriptional processing machineries. Because of these specific modifications, there is a general consensus on the presence of specific signature sequences and modifications for the identity of RNA classes. Based on extensive sequence work, it is possible to classify RNAs according to structural modifications. Figure 4 provides an outline for characteristics of RNA, and its modifications and brief examples are given in Table 5.

4.2. General Scheme of RNA Sequencing. The very first RNA sequence was obtained from the work of yeast alanine tRNA in 1965 [54]. In this work, the prerequisites for RNA sequence work were developed and described. Since then, it is a fundamental approach to establish oligonucleotide catalogs using specific RNases. One set is the catalog of $\mathrm{T} 1$ oligonucleotides produced by RNase T1. The other is the catalog of oligonucleotides produced by RNase A. The analytical method was based on UV spectral absorption in the earlier years. Subsequently, since 1970, isotopic labeling methods were widely used which are 1,000-fold more sensitive. Furthermore, many other improvements in RNA 


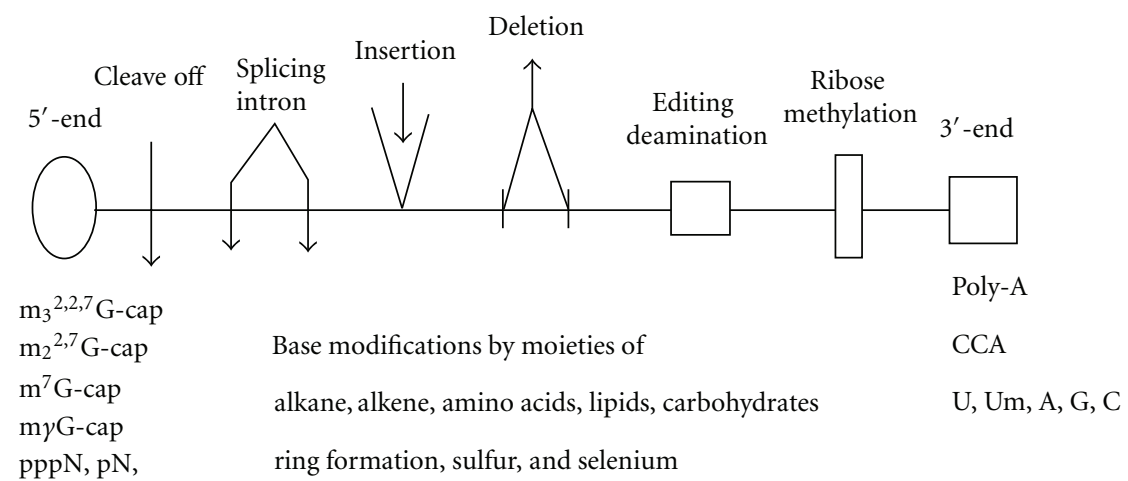

FIGURE 4: Summary of RNA modifications. Cotranscriptional and posttranscriptional RNA modifications are summarized.

TABLE 5: Examples of modification. All RNA species including high- and low-molecular-weight RNAs have their own signature sequences and modifications.

\begin{tabular}{|c|c|}
\hline RNA & Sequence and signature modification \\
\hline $\begin{array}{l}\text { hnRNAs } \\
\text { (Exons + Introns) }\end{array}$ & $\begin{array}{l}\mathrm{m}^{7} \mathrm{G} \text { cap, } \mathrm{m}^{6} \mathrm{~A}, \text { Poly-A, } \\
\text { splicing codes }\end{array}$ \\
\hline $\begin{array}{l}\text { mRNAs } \\
\text { (mainly exons) }\end{array}$ & $\begin{array}{l}\mathrm{m}^{7} \mathrm{G} \text { cap, } \mathrm{m}^{6} \mathrm{~A}, \text { Poly-A } \\
\text { Editing }(\mathrm{C} \rightarrow \mathrm{U} \& \mathrm{~A} \rightarrow \mathrm{I})\end{array}$ \\
\hline tRNAs & 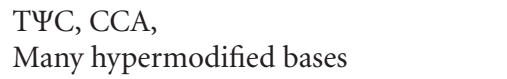 \\
\hline $45 \mathrm{~S}$ pre-rRNA & Repeated U sequences at $5^{\prime}$ end spacers \\
\hline 18S rRNA & $\mathrm{m}_{2}{ }^{6} \mathrm{~A}$, hypermodified $\mathrm{m}^{1} \mathrm{acp}^{3} \Psi$ \\
\hline $28 \mathrm{~S}$ rRNA & $\mathrm{NmNmNmN}, \mathrm{NmNmN}$ \\
\hline snRNAs, snoRNAs & $\begin{array}{l}\mathrm{m}_{3}^{2,2,7} \mathrm{G} \text { cap, } \mathrm{m} \gamma \mathrm{G} \text { cap } \\
\text { Types I, II, and III caps by ribose } \\
\text { methylations }\end{array}$ \\
\hline $\begin{array}{l}\text { mRNA } \\
\text { (Trypanosome) }\end{array}$ & $\begin{array}{l}\mathrm{m}^{7} \mathrm{Gpppm}_{2}{ }^{6,6} \mathrm{AmpAmpCmpm}{ }^{3} \mathrm{UmpAp} \\
\text { Insertion of repeated U sequence } \\
\text { Deletion of } U \text { sequence }\end{array}$ \\
\hline
\end{tabular}

sequence technique have made it possible to advance the rate of RNA sequence work greatly (Table 6).

Improvement was observed in the following areas: (1) RNA labeling techniques, (2) fractionation procedures (chromatography, electrophoresis, and gel procedures), (3) use of various RNases, (4) contig seeking, and (5) ladder sequence gel analysis. For example, based on labeling at the $5^{\prime}$-end with $\left[{ }^{32} \mathrm{P}\right]-\gamma$-ATP by polynucleotide kinase [56], it has become feasible to read a 150 nucleotide sequence using an endonuclease assisted ladder gel from the $3^{\prime}$-end. Also, based on labeling at the $3^{\prime}$-end with $\left[{ }^{32} \mathrm{P}\right]-5^{\prime}-\mathrm{pCp}$ by RNA ligase [57], it has become feasible to read approximately 150 nucleotides from the $5^{\prime}$-end. Together, these enhancements make it readily feasible to sequence RNA with approximately 300 nucleotides. In contrast to success in the sequence work for small RNAs, two challenges remained. One challenge is related to RNA size and the other is concerned with scarce abundance of RNA in the cell. With the discovery of reverse transcriptase, heat stable DNA polymerase, and recombinant technology, it became possible to produce cDNA, amplify, and clone by RT-PCR methods.
With high-efficiency RT-PCR, high-molecular-weight RNA with 10,000 nucleotides in length can be readily sequenced [59]. A remaining shortcoming of this approach is the inability to fully characterize modified nucleotides. However, ability to deal with long chain lengths and scarce abundance outweighs this limitation. cDNA-based methods clearly dominate any RNA sequence work that involves long RNA length or low RNA abundance. Examples are observed in the direct gene isolation for cleavage controlled processing RNAs (Pre-rRNA and rRNA) and cDNA method for premRNA and mRNAs. Therefore, as a result of accumulated methodologies, it becomes common that RNA sequence can be obtained through more than one scheme or type of technique, such as straight chemical approaches [60] or biotechnology-mediated approaches.

4.3. Outlined Steps of Sequence Work. Brief outlines are described for sequencing RNAs. It may be divided into two methods although combined methodology is in fact feasible.

\subsubsection{Direct Method of RNA Sequencing}

(a) Preliminary Examination of External Glycol Structures. In some cases, a rapid diagnostic examination is required. Most convenient procedures employ the use of specific antibodies against different forms of $5^{\prime}$-cap structure $\left(\mathrm{m}^{7} \mathrm{G}\right.$ cap or $\mathrm{m}_{3}{ }^{2,2,7} \mathrm{G}$ cap) and a oligo-dT column for poly-A affinity chromatography. Alternatively, a $\left[{ }^{3} \mathrm{H}\right]$-derivative method can be useful. The radioactive labeling of terminals was performed using the periodate oxidation method, followed by reduction with $\left[{ }^{3} \mathrm{H}\right]$-borohydride. $\mathrm{T}_{2}$ RNase digestion and fractionation by paper chromatography reveal the presence of the $3^{\prime}$-terminal and $5^{\prime}$-cap.

(b) Selection of Labeling Methods. RNA can be labeled in vivo (prelabeling) or in vitro (postlabeling).

In vivo labeling is carried out by incubation of living cells in the presence of $\left[{ }^{32} \mathrm{P}\right]$-phosphate in a phosphate-free medium. RNA is uniformly labeled by this method.

In vitro labeling is called postlabeling because it labels the isolated RNA with isotopic agents such as $\left.{ }^{32} \mathrm{P}\right]$-phosphate or $\left[{ }^{3} \mathrm{H}\right]$-borohydride. $\left[{ }^{32} \mathrm{P}\right]$-labeling can be carried out using kinase enzymes. The $5^{\prime}$-labeling is done with $\left[{ }^{32} \mathrm{P}\right]$-ATP by 
TABLE 6: General schemes of RNA sequencing. The direct and indirect methods of RNA sequencings are briefly outlined. The cDNA and DNA pathways are considered indirect methods.

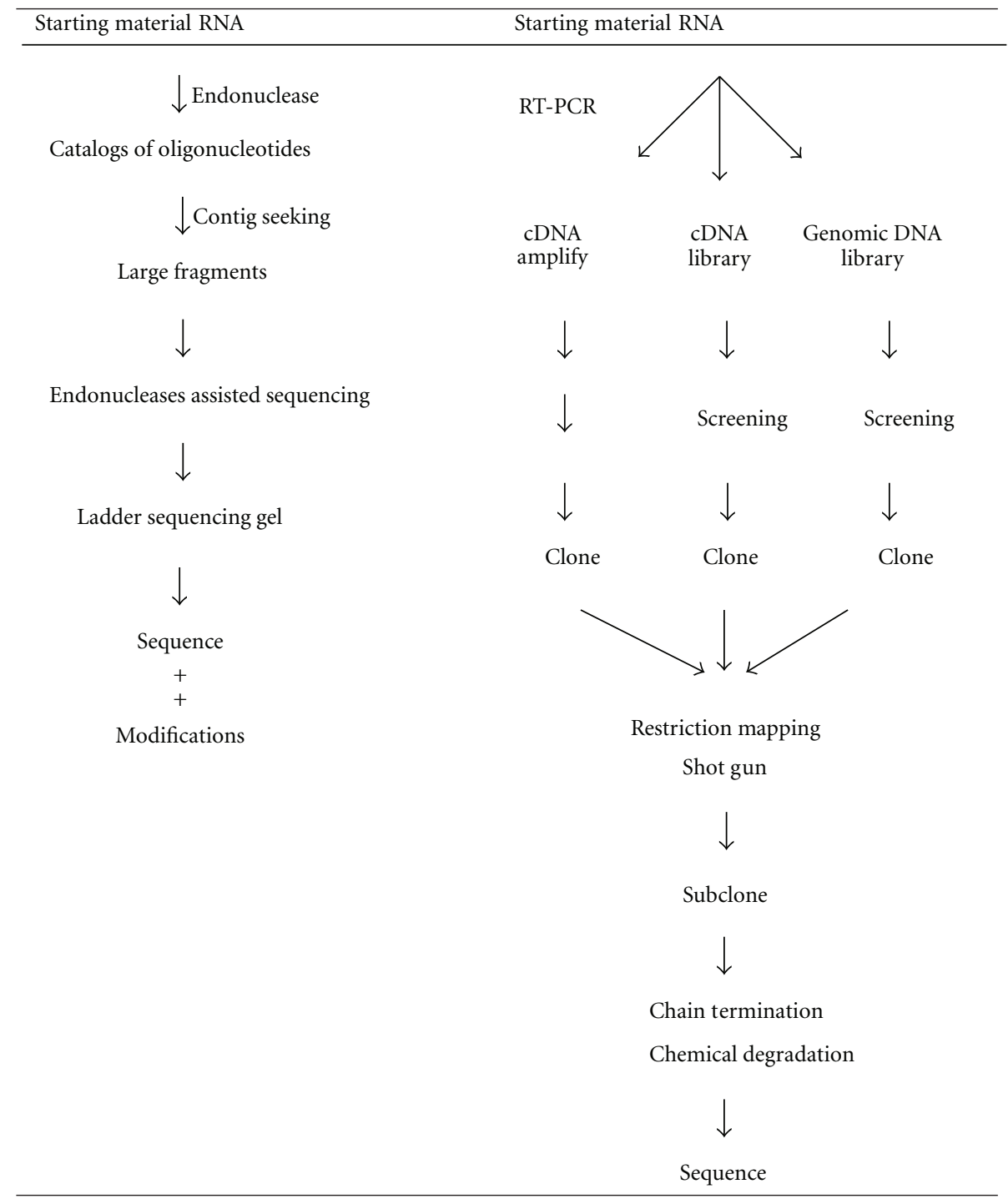

polynucleotide kinase, that is, provided the $5^{\prime}$-end is free from phosphate. If the $5^{\prime}$-end is blocked by the presence of a $5^{\prime}$-cap structure, the pyrophosphate moiety must be removed by a pyrophosphatase and phosphatase. And then the kinase method can be employed to introduce the tracer. Labeling at the $3^{\prime}$-end is done with $\left[{ }^{32} \mathrm{P}\right]-\mathrm{pCp}$ by RNA ligase. The $\left[{ }^{3} \mathrm{H}\right]$-derivative (nucleotide diol) with $\left[{ }^{3} \mathrm{H}\right]$ borohydride indicates that the $3^{\prime}$-end is free from phosphate or any other blocking structures. A shortcoming of $\left[{ }^{32} \mathrm{P}\right]-$ labeling is the short half-life of the isotope which provides a working period of approximately 4 half-lives. The main limitation of the $\left[{ }^{3} \mathrm{H}\right]$-labeling method is weak energy of the tritium isotope. This can make the reading of the autoradiograph for a ladder sequencing gel very difficult.

(c) Initial Reading of Sequence by Ladder Sequencing Gel. To obtain the nucleotide sequence of RNA quickly without characterization of modified nucleotides, it is common to use the endonucleases-dependent sequencing technique [61]. Terminal labeled RNA ( $5^{\prime}$-end or $3^{\prime}$-end) is partially digested with specific endonucleases $\left(\mathrm{T}_{1}, \mathrm{U}_{2}, \mathrm{~A}\right.$, phys $\mathrm{I}$, and others), and each product is loaded in parallel on a $10-15 \%$ denaturing polyacrylamide gel. Note that if crude acrylamide is used, the running temperature of the gel can quickly rise to $60-70^{\circ} \mathrm{C}$. Since the mode of cleavage is known, it is possible to discern $\mathrm{G}\left(\mathrm{T}_{1}\right), \mathrm{A}\left(\mathrm{U}_{2}\right), \mathrm{U}$ and $\mathrm{C}(\mathrm{A})$ and C-resistance (Phys I). It is not uncommon to read an RNA sequence using this method within one day.

(d) Base Composition. There are two technical approaches that can be used to determine RNA base composition (levels of nucleotides or of nucleosides).

RNase $\mathrm{T}_{2}$ or alkali $(0.3 \mathrm{~N} \mathrm{KOH})$ is used to complete hydrolysis. But alkali $(0.3 \mathrm{~N} \mathrm{~K} / \mathrm{NaOH})$ is not preferred because 
it destroys 7-methyl purines. Prelabeled $\left[{ }^{32} \mathrm{P}\right]$-RNA is hydrolyzed, and its products are separated by 2 -dimensional paper chromatography followed by autoradiography [62] Since the standard separation pattern is known, various modified nucleotides are readily identified by comparison [56].

Alternatively, after cold RNA is digested into constitu-ent nucleotides, which are subsequently dephosphorylated by phosphatase, the resulting nucleosides are converted into $\left[{ }^{3} \mathrm{H}\right]$-derivatives and separated by thin layer chromatography. The separated nucleosides (including all modified nucleosides except 2'-O-methylated nucleosides) are detected by fluorography and identified based upon a standard migration pattern (Figure 5) [9].

(e) Catalogs of Oligonucleotides. Two types of catalogs are made. One is an RNase $T_{1}$ catalog, and the other is an RNase A catalog.

To map oligonucleotides, two necessary procedures are essential. The first is to prepare labeled oligonucleotides and the second is to fractionate two-dimensionally.

To obtain labeled oligonucleotides, three approaches are possible.

(1) Use of prelabeled $\left.{ }^{32} \mathrm{P}\right]$-RNA for specific endonuclease digestion.

(2) $5^{\prime}$ labeling after enzyme digestion using [ $\left.{ }^{32} \mathrm{P}\right] \mathrm{ATP}$ and polynucleotide kinase.

(3) $3^{\prime}$ labeling after endonuclease digestion and removal of resultant $3^{\prime}$-phosphate by phosphatase. Then the labeled derivatives can be formed by $\left[{ }^{32} \mathrm{P}\right]-5^{\prime}-\mathrm{pCp}$ and RNA ligase or periodate oxidation followed by $\left[{ }^{3} \mathrm{H}\right]$-borohydride reduction.

To Map Oligonucleotides. There are a number of different techniques. However, the most common are a combination of high voltage paper electrophoresis on cellulose acetate at $\mathrm{pH} 3.5$ and high voltage DEAE paper electrophoresis (7\% formic acid) or high voltage electrophoresis on cellulose acetate at $\mathrm{pH} 3.5$ followed by DEAE homochromatography at $60-70^{\circ} \mathrm{C}$. Another method that can be used is twodimensional thin layer (PEI) chromatography using twosolvent systems [63]. Detection is performed by autoradiography. It is notable that $\mathrm{T} 1$ oligonucleotides from $45 \mathrm{~S}$ prerRNA can be fractionated into approximately 200 spots by homochromatography [64].

To Sequence Oligonucleotides. Several enzymatic digestions can be exploited.

The recovered $\left[{ }^{32} \mathrm{P}\right]$-oligonucleotides (prelabeled) are subjected to secondary digestions with $\mathrm{RNase} \mathrm{U}_{2}$ for placement of $A$ residues, RNase $T_{1}$ for $G$ residues, RNase $A$ for $\mathrm{U}$, and $\mathrm{C}$ residues plus other endonucleases. Treatment with exonucleases (spleen phosphodiesterase, snake venom phosphodiesterase), and partial digestion with the enzymes above is required to sequence RNA. In each step, nucleotide composition is determined.

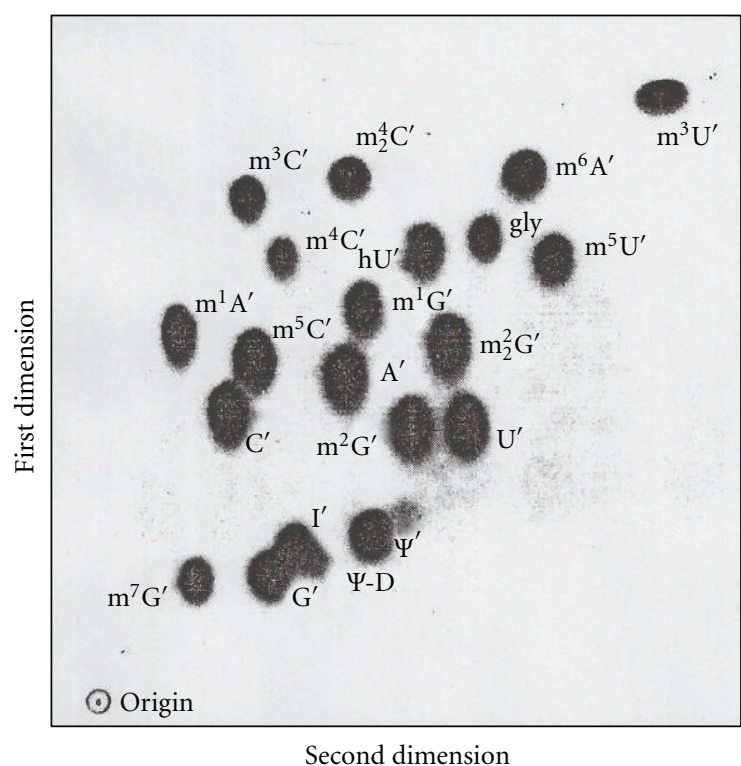

FIGURE 5: Two-dimensional map of standard nucleosides [9]. The $\left[{ }^{3} \mathrm{H}\right]$-labeled standard nucleoside derivatives are separated by twodimensional thin layer chromatography. The first dimension is shown from bottom to top and the second dimension from left to right. Solvent systems are in the text. $\mathrm{N}^{\prime}$ represents trialcohol derivatives of representative nucleosides.

To Determine the Sequence of $5^{\prime}$-Labeled $\left[{ }^{32} \mathrm{P}\right]$-Oligo-Nucleotides. A mobility shift test can be applied [56]. After partial hydrolysis with snake venom phosphodiesterase the product is fractionated by homochromatography or PEI thin layer chromatography. The mobility shift pattern is produced according to the step-wise loss of each nucleotide from the 3 '-end. The resulting pattern can be used to read the sequence of the oligonucleotides.

To Determine the Sequence of $\left[{ }^{3} \mathrm{H}\right]$-Oligonucleotides. The procedures used for prelabeled $\left[{ }^{32} \mathrm{P}\right]$-oligonucleotides are applicable. Secondary digestion methods and accompanying $\left[{ }^{3} \mathrm{H}\right]$-derivative methods for the determination of nucleotide composition can be carried out.

It may be necessary to strengthen the catalog of oligonucleotides. Generally this involves the expansion of the catalog to provide contiguous overlapping sequences. A feasible approach is to produce large fragments (purified on 10$15 \%$ denaturing polyacrylamide gel electrophoresis) and identify the overlapping oligonucleotides. Usually a limited fragmentation by a diluted endonuclease at low temperature or water hydrolysis may produce large overlapping fragments [63]. Examination of large fragments, as done above for ladder gel sequencing and catalogs, can often clarify any ambiguity encountered. An excellent example of one hit hydrolysis is observed in the work on tRNA structure [63]. Based on these very same methods, it can be summarized that many small RNAs have been sequenced. These include tRNAs, pre-tRNAs, 4.5S RNA I, 5S rRNA, 5.8S rRNA, snRNAs, snoRNAs, 7S RNA, and some fragments of prerRNA, 28S rRNA, and $18 \mathrm{~S}$ rRNA. 
4.3.2. Indirect Method of RNA Sequencing. The indirect method of RNA sequencing using cDNA or DNA gene analysis was developed as part of explosive advancements with DNA biotechnology. The direct RNA sequencing method proved useful for the characterization of small RNAs ( 100-300 nt). However, sequencing high-molecularweight (HMW) RNAs proved to be too difficult. Moreover, HMW RNAs that are scarce abundance often do not meet the sample amounts required by the former methods. The search for a solution to this dilemma was successful. One solution involved the isolation of the gene that codes for a specific RNA and the other is to synthesize cDNA which can also be used to isolate a specific RNA gene. Using DNA biotechnology, it proved possible to scale up and solve "The Human Genome Project." Several genomes have been sequenced, specifically the human $(2.9 \mathrm{~Gb})$ and mouse $(2.5 \mathrm{~Gb})$ genomes [65-67]. In well equipped laboratories, it is possible to sequence DNA at the rate of $10^{6}-10^{7} \mathrm{nt} /$ day. This technology has been widely commercialized and is currently available as kits for cDNA cloning, sequencing, along with enzymes and equipment that supports automatic sequencing. The principal objective of the genomic approach was to determine the sequences of the coding genes. Vast collections of sequence data were compiled for RNAs, cDNAs, and genomic structures, revealing the base sequences for a number of RNAs. As a result of this work.

(a) Unidentified proteins have been predicted to number 25,243 ; whereas the known protein number is 15,337 .

(b) A majority of mRNA species (95\%) mature through alternative splicing mechanisms.

(c) Disease genes are estimated to be 2,577 in number.

(d) Point mutations are 31,250 in number; half of disease-causing mutations are attributed to aberrant splicing (disruption of splicing codes) whereas other forms of mutation include disruption of the genetic code.

(e) Disruption of splicing code occurs at the splice site and enhancer/silencer sites of exonic and intronic sequences.

(f) Pathogenic sequences that occur as a result of splice code mutations (transition and transversion) cause aberrant modifications of a variety of RNAs $[68,69]$.

Recently, evidence has been accumulating that suggests a need to revise earlier estimates of the number of transcriptional products arising from the genomic information. Paradoxical findings were obtained that contradicted earlier and more conservative estimates of the proteasomes size $(50,000)$, in fact, the cellular transcripts are 2-3 times higher than estimated earlier $[50,51]$. Also, $50 \%$ of the transcripts were comprised of noncoding RNA, some of which are polyadenylated. This paradoxical manifestation has led to the second generation of genomic work, strictly based on RNA characterization. It is worth emphasizing that this has become the second genomic frontier where a reevaluation of the first genomic work is necessary. The present task is more daunting than the "The first Generation Genome Project."
The task at hand is to resequence the genome and then categorize and catalogue the ncRNA species by utilizing all available sequence means, including direct sequencing and DNA microarray techniques.

The next step is to construct secondary structures according to enzyme susceptibility and computer-aided base pairing. Interacting proteins will need to be defined by biochemical, NMR, X-ray, and cryo-EM methods.

\section{Reagent and Procedures Required for Sequencing}

\subsection{RNA-Specific Cleavage Reactions (2'-OH Required Reaction)}

(1) Mild alkaline hydrolysis $(0.3 \mathrm{~N} \mathrm{KOH})$ produces $3^{\prime}$ monophosphorylated nucleotides.

(2) $T_{1}$ RNase cleaves phosphodiester bonds after G base producing $3^{\prime}$ GMP at the $3^{\prime}$ ends.

(3) RNase A cleaves phosphodiester bonds after pyrimidines ( $\mathrm{U}$ and $\mathrm{C}$ ) producing $3^{\prime}$ phosphates at $3^{\prime}$ ends.

(4) $T_{2}$ RNase cleaves all phosphodiester bonds with a preference for A residues, producing $3^{\prime}$ monophosphates.

(5) $U_{2}$ RNase cleaves phosphodiester bonds after A base, producing $3^{\prime}$ monophosphates.

The mechanism catalyzed by alkaline hydrolysis, RNase A, $T_{1}$ RNase, $T_{2}$ RNase and $\mathrm{U}_{2}$ RNase involves a $\mathrm{S}_{\mathrm{N}} 2(\mathrm{p})$ mechanism attacking $2^{\prime}$-hydroxyl groups on the adjacent internucleotidic phosphodiester bond to displace the $5^{\prime}$ hydroxyl group of the neighboring nucleotides and generate a $2^{\prime}, 3^{\prime}$-cyclic nucleotide intermediate. A subsequent hydrolysis of the $2^{\prime}, 3^{\prime}$-cyclic nucleotide yields a final product, a $3^{\prime}$ mononucleotide (Figure 6).

\subsection{The Enzymes Cleaving All Phosphodiester Bonds Including 2'-O-Methylated Ribose}

(1) $P_{1}$ RNase: the enzymatic digestion by $P_{1}$ RNase cleaves all phosphodiester bonds (except pyrophosphate linkages), producing $5^{\prime}$ monophosphorylated nucleotides.

(2) The enzymes acting from the ends for sequencing fragments

(a) Snake venom phosphodiesterase (phosphodiesterase I) cleaves phosphodiester bonds, as well as pyrophosphate bonds producing $5^{\prime}$ monophosphorylated nucleotides. It cleaves single-stranded RNA or DNA from the $3^{\prime}$ end in a progressive manner.

(b) Spleen phosphodiesterase (phosphodiesterase II) produces $3^{\prime}$ monophosphorylated nucleotides cleaving from nonphosphorylated $5^{\prime}$ ends of single-stranded RNA or DNA. 


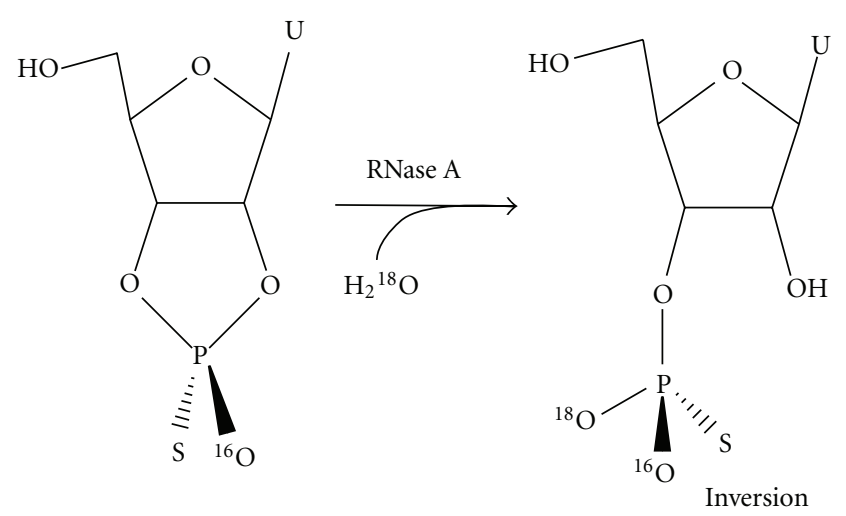

Stereochemistry of the reaction catalyzed by RNase A

Figure 6: Stereochemistry of the reaction catalyzed by RNase A [10]. The intermediary $2^{\prime}, 3^{\prime}$ cyclic nucleotide (cNp or cNMP) is hydrolyzed to a $3^{\prime}$ phosphorylated mononucleotide. Other $2^{\prime}-\mathrm{OH}$ requiring enzymatic and alkaline hydrolysis may go through the same path.

\subsection{Other Enzymes Utilized for Sequencing}

(1) Alkaline phosphatase removes phosphate from 3' and $5^{\prime}$ ribose moieties.

(2) Pyrophosphatase will only cleave pyrophosphate linkages. There are pyrophosphatases from tobacco and potato as well as from Crotalus adamanteus venom type II.

Using varying combinations of fragmentation methods, it becomes possible to obtain fragments that range in size from nucleosides to very large fragments.

\subsection{Chemical Modifications Used for Sequencing}

5.4.1. CMCT Reaction. Originally reported by Gilham [73], the adduct formation of uridine and guanosine components of RNA with CMCT made uridine residues resistant to RNase A. In addition it has been shown that CMCT reacts with pseudouridine and to a lesser extent with inosine. This reaction takes place on $\Psi(\mathrm{N} 1, \mathrm{~N} 3), \mathrm{U}(\mathrm{N} 3), \mathrm{G}(\mathrm{N} 1)$, and $\mathrm{I}(\mathrm{N} 1)$, and cold dilute ammonia removes the adducts from $\Psi(\mathrm{N} 1)$ and hot concentrated ammonia removes remaining adducts from $\Psi(\mathrm{N} 3)[74,75]$. These properties have been used to block RNase A digestion at $\mathrm{U}$ but not at $\mathrm{C}$ as well as to differentiate $U$ from $\Psi$ (Figure 7) [11].

Direct chemical methods for sequencing RNA using dimethyl sulfate, diethyl pyrocarbonate, and hydrazine followed by aniline- $\beta$-elimination have been successfully utilized in $5 \mathrm{~S}$ RNA and 5.8S RNA sequence analysis [60].

5.4.2. DMS (Dimethylsulfate). This has been used to identify secondary structures as well as for the synthesis of standard $\mathrm{m}_{3}{ }^{2,2,7} \mathrm{G}$. The properties of DMS modifying adenosine (N1) and cytosine (N3) make modified nucleotides unable to base-pair. For this reason RT-PCR stops one nucleotide before the modified nucleotide enabling the location of a modified nucleotide as well as differentiating the single-stranded from double-stranded regions of RNA. DMS also has been used for synthesis of $m_{3}^{2,2,7} G$ from N2,N2-dimethylguanosine. For this synthesis, the reaction has been carried out by the methods of Saponara and Enger [76]. Twenty milligrams of N2,N2-dimethylguanosine were suspended in $400 \mu \mathrm{L}$ of dimethylacetamide containing $10 \mu \mathrm{L}$ dimethylsulfate. The mixture was shaken for 15 hours at room temperature and then centrifuged to remove insoluble products. The supernatant was adjusted to $\mathrm{pH}$ 8.0 with concentrated ammonia and then placed on a phosphocellulose column $(1 \times 50 \mathrm{~cm})$ at $\mathrm{pH} 7.0(0.001 \mathrm{M}$ ammonium acetate). A linear gradient of $0.001-0.3 \mathrm{M}$ ammonium acetate was used to elute the samples. One major peak of the product $\left(\mathrm{m}_{3}{ }^{2,2,7}\right.$ trimethylguanosine $)$ was found between two minor peaks (corresponding to N2,N2-dimethylguanosine and 7-methylguanosine). The product was lyophilized and identified as $\mathrm{m}_{3}^{2,2,7} \mathrm{G}$ by mass spectrometry [12]. The summary of reagent and procedures required for sequencing is provided in Table 7.

The nucleotides or nucleosides obtained can be separated by column chromatography, paper electrophoresis or thin layer chromatography to determine the number of $G, A$. $\mathrm{U}, \mathrm{C}$ and modified residues in the fragments or in the molecule. These 4 bases have specific UV spectra and chemical reactivity to identify the nature of the bases in comparison with known standards. The unusual nucleoside, trimethylguanosine, has its specific UV absorption spectra (Figure 8) and mass spectrometric characteristics (Figure 9).

\section{The Major snRNA Sequenced}

The first nuclear small RNA sequenced was 4.5S RNAI [77] shown in Figure 37. This RNA contains the RNA polymerase III promoter box A and box B like motifs and shows interesting enhancer motif elements resembling the Alu element transcript. The RNA polymerase III promoter areas are underlined and the first nucleotide of the enhancer motif is marked by colored letters. The red color is SF2/ASF (4 motifs), blue color is SC35 (3 motifs), green color is SRp40 (6 motifs), and yellow color is SRp55 (1 motif) (Figure 10(a)). It also exhibits $3^{\prime}$-splice sites marked by [AG] as well as branch sites with the highest score marked by \{CACCUAU\} (Figure 10(b)). The ESE (exonic splice enhancer), splice sites (Figure 10(c)), and branch sites were examined by ESEfinder $3.0[13]$.

In comparison with known Alu elements in the FMR1 gene, the resemblance of $4.5 \mathrm{~S}$ RNA I in ESE, 5'SS, BS, and $3^{\prime}$ SS distribution (Table 8) suggests that 4.5S RNA I is more likely derived from an Alu gene expressed in Novikoff hepatoma cells.

The Alu element has been shown to have many different functions in transcription, splicing, exonization [78], gene insertions (transposons), and DNA replication. It is interesting to observe that the $(+)$ oriented Alu has more 


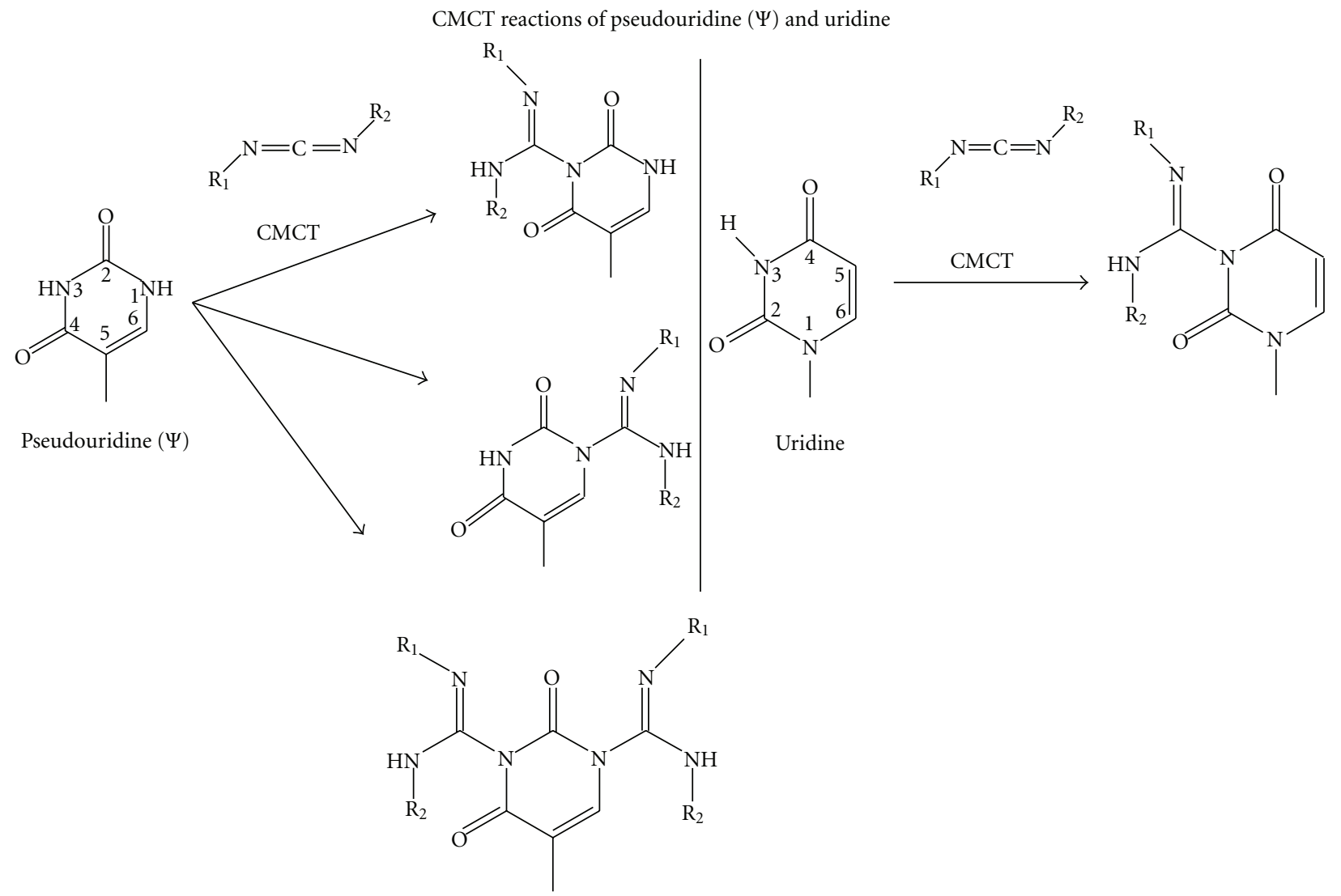

CMCT; $\mathrm{N}$-cyclohexyl- $\mathrm{N}^{\prime}-\beta$-(4-methylmorpholinium) ethylcarbodiimide metho-p-toluensulphonate

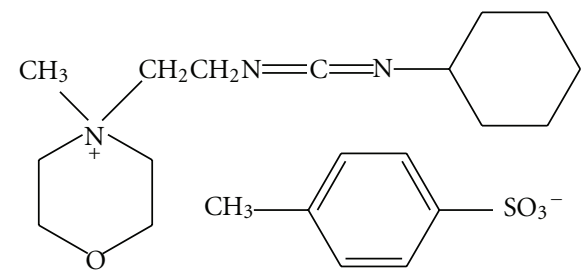

FIgure 7: The CMCT reaction of pseudouridine $(\Psi)$ and uridine, and the structure of CMCT [11]. Adducts formed with CMCT on $\Psi$ and $\mathrm{U}$ are shown. This adduct formation prevents the cleavage by RNase A at $\mathrm{U}$ but not at $\mathrm{C}$. The mild alkaline treatment of reaction products destroys the $U$ but not the $\Psi$. These differences were utilized to locate the position of $\Psi$ by reverse transcriptase.

$5^{\prime}$ splice sites and the $(-)$ oriented Alu has more $3^{\prime}$ splice sites. It may suggest that exonization may occur from the $5^{\prime}$ side of $(+)$ Alu elements and $3^{\prime}$ side of $(-)$ Alu elements. The SRP RNA (7SL RNA) has Alu elements in its sequence [79]. Whether the Alu is derived from 7SL or Alu is exonized to $7 \mathrm{SL}$ is not clear. Subsequently, other snRNAs have been sequenced.

The sequences of the capped snRNAs are described in Figure 11. The pivotal sequences needed for functions are marked by colors.

In the course of any sequence work, there are always challenges in resolving unknown structures at the $5^{\prime}$ end portions which contain the $5^{\prime}$-cap structure and various modified nucleotides. The experimental steps required to discern this complicated region are described.

\section{Nucleotide Composition and Modified Nucleotides in snRNAs}

The compositional analyses were carried out by UV analysis as well as isotope labeling analysis. For example, UV analysis required $\sim 10 \mathrm{mg}$ of $\mathrm{U} 2 \mathrm{RNA}$.

7.1. RNA Terminal Labeling with $\left[{ }^{3} \mathrm{H}\right]-\mathrm{KBH}_{4}$. The purified nuclear RNAs were separated by sucrose gradient centrifugation which separates 4-8S RNA, 18S RNA, 28S RNA, $35 \mathrm{~S}$ RNA, and 45S RNA isolated from nuclei of rat liver, Walker tumor, or Novikoff hepatoma cells. As an initial step for the structural characterization, $3^{\prime}$ end nucleosides were labeled by the procedure of sodium periodate $\left(\mathrm{NaIO}_{4}\right)$ oxidation and potassium borohydride $\left(\left[{ }^{3} \mathrm{H}\right]-\mathrm{KBH}_{4}\right)$ reduction. 
TABLE 7: Reagents and procedures required for sequencing.

\begin{tabular}{|c|c|}
\hline $\begin{array}{l}\text { Detection of external } \\
\text { modification }\end{array}$ & $\begin{array}{l}\text { Oligo-dT column } \\
\text { Borate column } \\
\text { Antibodies against } \mathrm{m}^{7} \mathrm{G}, \mathrm{m}_{3}{ }^{2,2,7} \mathrm{G} \text {, and } \\
\text { others }\end{array}$ \\
\hline Labeling & $\begin{array}{l}\text { Prelabeling (in vivo) with } \\
{\left[{ }^{32} \mathrm{P}\right] \text {-phosphate }} \\
\text { Postlabeling (in vitro) } \\
5^{\prime}\left[{ }^{32} \mathrm{P}\right] \text { labeling } \\
3^{\prime}\left[{ }^{32} \mathrm{P}\right] \text { labeling } \\
3^{\prime} \text { and } 5^{\prime}\left[{ }^{3} \mathrm{H}\right] \text {-derivative labeling }\end{array}$ \\
\hline \multicolumn{2}{|l|}{ Enzymes } \\
\hline Endonucleases & 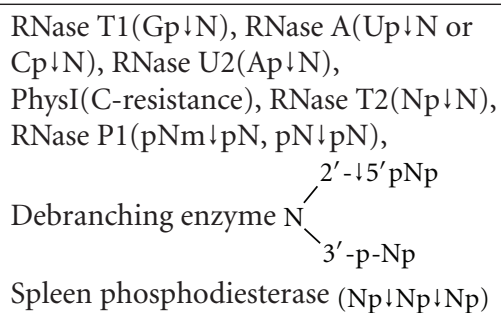 \\
\hline \multirow[t]{2}{*}{ Exonuclease } & $\begin{array}{l}\text { Snake venom phosphodiesterase } \\
\left(\mathrm{N} \downarrow \mathrm{pN} \downarrow \mathrm{pNp} \text { and } \mathrm{N} 5^{\prime} \mathrm{p} \downarrow \mathrm{p} \downarrow \mathrm{p} 5^{\prime} \mathrm{N}\right) \\
\longleftarrow\end{array}$ \\
\hline & $\begin{array}{l}\text { Pyrophosphatase }(-p \downarrow p-) \\
\text { Phosphatase }(\mathfrak{p} \downarrow N \text { and } N \downarrow p)\end{array}$ \\
\hline \multicolumn{2}{|l|}{ Chemicals } \\
\hline СMCT & React with $U>\Psi>G>I$ on ssRNA \\
\hline DMS & Methylate $\mathrm{G}>\mathrm{A}>\mathrm{C}$ on ssRNA \\
\hline $\begin{array}{l}\text { Diethyl } \\
\text { pyrocarbonate }\end{array}$ & React with $A>G$ \\
\hline Hydrazine & React with $\mathrm{U}>>\mathrm{C}>\mathrm{T}$ \\
\hline Limited hydrolysis & $\begin{array}{l}\text { Formamide } \\
\text { Hot water }\left(80^{\circ} \mathrm{C}\right)\end{array}$ \\
\hline Fractionation & $\begin{array}{l}\text { 2D acrylamide gel electrophoresis } \\
\text { 2D homochromatography } \\
\text { 2D electrophoresis } \\
\text { 2D paper chromatography } \\
\text { 2D thin layer chromatography }\end{array}$ \\
\hline
\end{tabular}

The reaction was carried out in $0.1 \mathrm{M}$ sodium acetate buffer at $\mathrm{pH} 5$ with freshly prepared $\mathrm{NaIO}_{4}$ in the dark for 1 hour and precipitated the RNA with ethanol. The RNA was redissolved in the same buffer and treated with ethylene glycol to destroy excess $\mathrm{NaIO}_{4}$. The RNA was precipitated with ethanol and redissolved in $0.1 \mathrm{M}$ sodium phosphate buffer, $\mathrm{pH}$ 7.7, and treated with radioactive $\left[{ }^{3} \mathrm{H}\right]-\mathrm{KBH}_{4}$ [38]. These reaction products would have tritium labeling in cisalcohols from cis-aldehyde oxidation products of the $2^{\prime}$ and $3^{\prime}$ hydroxyls of ribose, assuming all $3^{\prime}$ ends of RNA have accessible $2^{\prime}$ and $3^{\prime} \mathrm{OH}$ groups (Figure 12 ).

The labeled 4-8S RNAs were separated by preparative polyacrylamide gel electrophoresis (Figure 13) and DEAESephadex column chromatography (Figure 14) to purify individual snRNAs (U1, U2, U3, 4.5S RNA I, II, and III, 5S RNA I, II, and III).

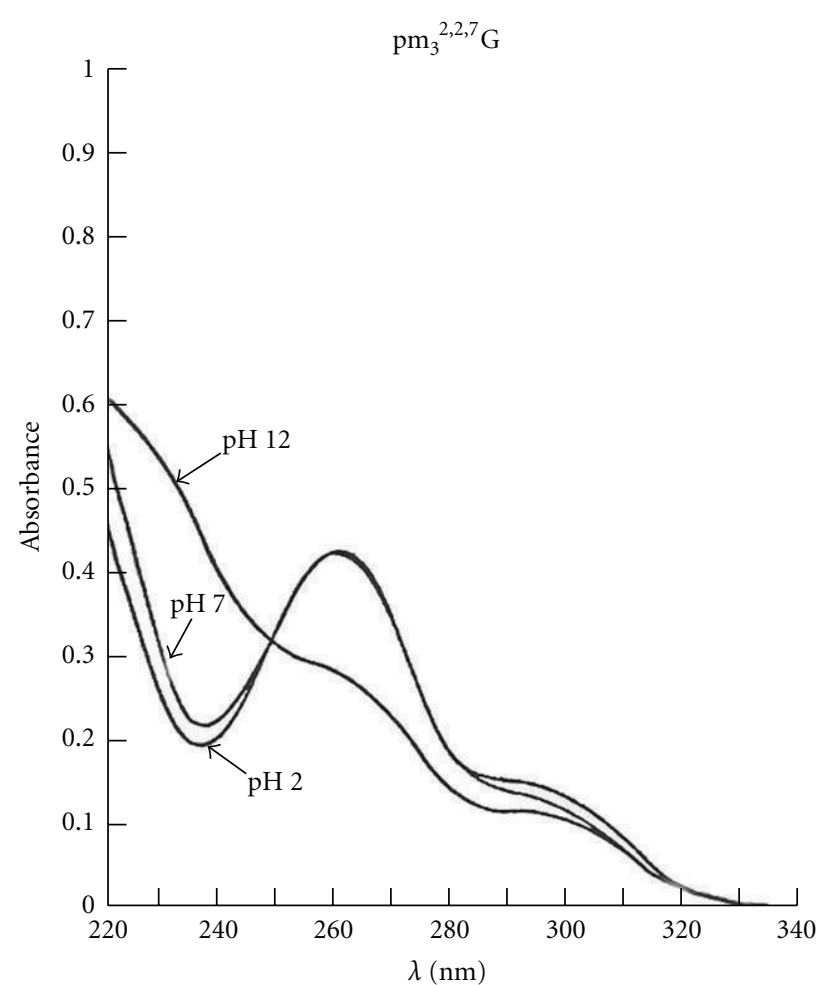

FIgURE 8: The UV spectra of $\mathrm{pm}_{3}{ }^{2,2,7} \mathrm{G}[12]$. The ultraviolet absorption spectra were recorded on a Cary 14 spectrometer immediately after addition of compound to solutions at $\mathrm{pH} \mathrm{2,} \mathrm{7,} \mathrm{and} 12$.

Alkaline hydrolysis of these RNAs produced 3 ' end nucleoside trialcohol derivatives (Table 9) which were subsequently identified by paper chromatography.

The RNA that appeared to be pure for sequencing was 4.5S RNA I which had $87.4 \% \mathrm{U}$ at the $3^{\prime}$ terminus and only $6.5 \%$ unknown radioactivity at the origin. Unexpectedly, U1, U2, U3, 4.5S RNA II, and some of 5S RNA (5S RNA III/U5) had $\sim 50 \%$ labeling in alkaline-resistant fragments that did not move as nucleoside derivatives. The 4.5S RNA III was not labeled by this procedure suggesting a blocked $3^{\prime}$ end (Figure 14). The U1, U2, and U3 RNAs were labeled with tritium, digested with RNase A, and separated on a DEAESephadex column (Figure 15).

The oligonucleotides were digested with $T_{1}$ RNase and rechromatographed, and only the U3 oligonucleotide was shortened by one nucleotide, indicating the presence of one $\mathrm{G}$ adjacent to RNase A susceptible pyrimidine [80]. In the course of sequencing U1, U2, U3 RNAs, it was found that the oligonucleotides with $\mathrm{m}_{3}{ }^{2,2,7} \mathrm{G}$ was coming from the $5^{\prime}$ end segments. The only way $2^{\prime} 3^{\prime}$ hydroxyls could be at $5^{\prime}$ end was $5^{\prime}-5^{\prime}$ pyrophosphate linkage to the rest of the RNA molecules [36]. The RNase A and $T_{1}$ RNase resistant oligonucleotides were digested with various enzyme combinations including snake venom phosphodiesterase, alkaline phosphatase, $\mathrm{P}_{1}$ RNase, $\mathrm{T}_{2}$ RNase, and $\mathrm{U}_{2}$ RNase into nucleosides. The component nucleosides were identified by mass spectrometry, U.V. spectroscopy, HPLC (high pressure liquid chromatography), paper chromatography, and thin layer chromatography. $[12,16,37,58]$. 

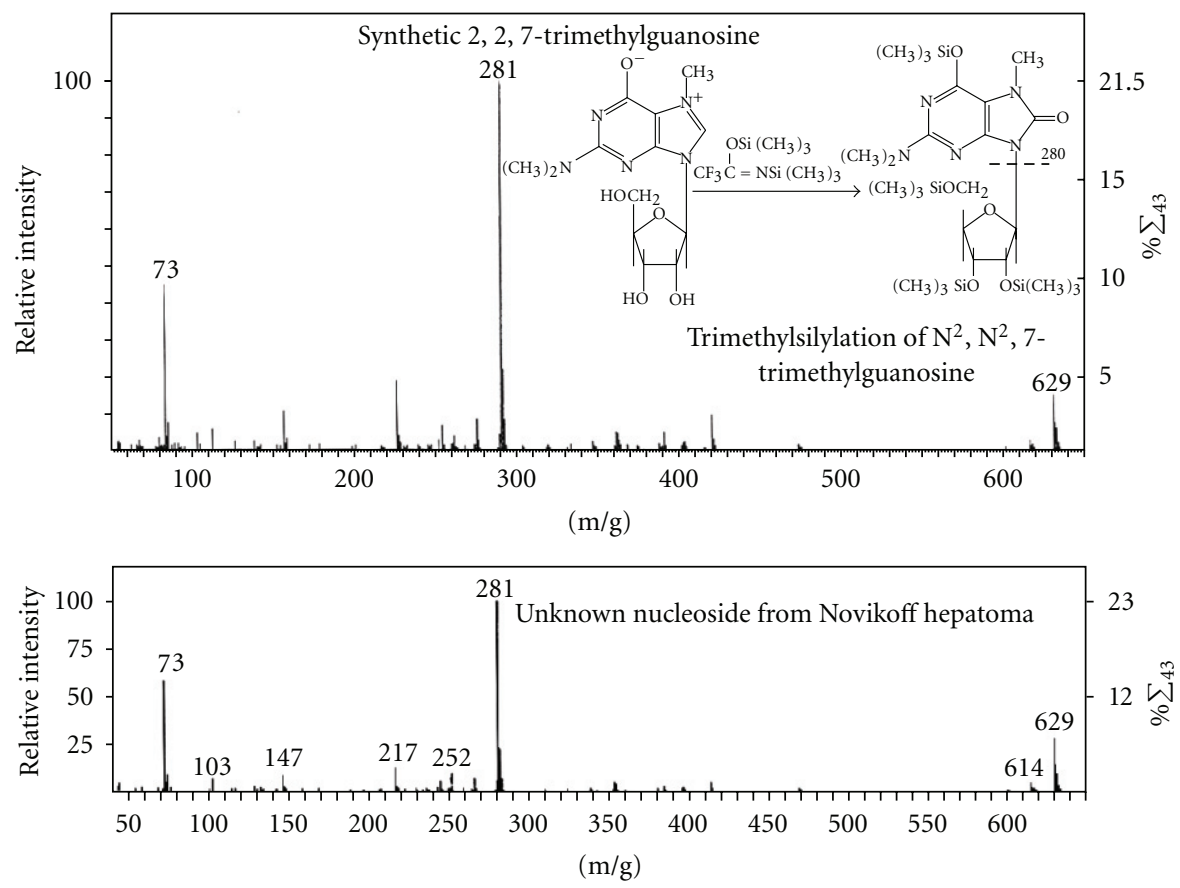

FIGURE 9: The mass spectra of trimethylguanosine [12]. The synthetic $\mathrm{m}_{3}{ }^{2,2,7} \mathrm{G}$ and unknown nucleoside from U2 RNA were trimethylsilylated and subjected to LKB 9000 gas chromatograph-mass spectrometer. The mass spectrum of the unknown nucleoside from U2 RNA was identical to synthetic $\mathrm{m}_{3}^{2,2,7} \mathrm{G}$.

TABle 8: Distribution of ESE, 5' splice sites, branch sites, and $3^{\prime}$ splice sites. The ESE, $5^{\prime}$ splice site, branch site, and $3^{\prime}$ splice site in $4.5 \mathrm{~S}$ RNA I and Alu elements in FMR1 gene transcript are screened by ESE finder (version 3) [13]. For this comparison, the number of motifs is calculated per 100 nucleotides. The motif patterns in Alu elements are all very much alike and the 4.5S RNA I resembles them. A difference is found in that $5^{\prime}$ splice sites in (+) Alu are more than in (-) Alu and $3^{\prime}$ splice sits are more in (-) Alu than in (+) Alu.

\begin{tabular}{lcccccccc}
\hline & SF2/ASF & SC35 & SRp40 & SRp55 & Total & 5'SS & BS & 3'SS \\
\hline Novikoff 4.5S RNA I (96 nt) & 3.65 & 3.13 & 6.25 & 1.04 & $\mathbf{1 4 . 0 7}$ & 0 & 10.4 & 2.08 \\
Human FMR1 Alu1(+) (252 nt) & 4.96 & 7.54 & 6.35 & 1.59 & 20.44 & 3.97 & 9.13 & 5.56 \\
Human FMR1 Alu4(+) (295 nt) & 4.41 & 4.41 & 1.69 & 2.03 & 12.54 & 2.37 & 10.9 & 2.37 \\
Human FMR1 Alu5(+) (246 nt) & 5.69 & 5.28 & 4.47 & 1.22 & 16.66 & 4.47 & 8.54 & 2.44 \\
Human FMR1 Alu7(+) (290 nt) & 6.21 & 2.41 & 3.10 & 0.34 & 12.06 & 3.79 & 10.3 & 2.07 \\
Human FRM1 Alu8(+) (288 nt) & 5.21 & 3.47 & 3.82 & 0.69 & 13.19 & 3.47 & 8.68 & 2.43 \\
(+) Alu Av. & 5.30 & 4.62 & 3.89 & 1.17 & $\mathbf{1 4 . 9 8}$ & $\mathbf{3 . 6 1}$ & 9.51 & 2.97 \\
Human FMR1 Alu2(-) (298 nt) & 3.69 & 6.04 & 5.03 & 1.34 & 16.10 & 0.67 & 14.1 & 4.70 \\
Human FMR1 Alu3(-) (285 nt) & 4.92 & 7.02 & 5.61 & 2.11 & 19.66 & 3.16 & 13.7 & 4.56 \\
Human FMR1 Alu6(-) (290 nt) & 4.31 & 5.52 & 4.48 & 1.38 & 15.69 & 2.76 & 13.5 & 4.48 \\
(-) Alu Av. & 4.31 & 6.19 & 5.04 & 1.61 & $\mathbf{1 7 . 1 5}$ & 2.20 & 13.8 & $\mathbf{4 . 5 8}$ \\
Human FMR1 Total Alu(+\&-) Av. & 4.93 & 5.21 & 4.32 & 1.34 & $\mathbf{1 5 . 8 0}$ & 3.08 & 11.1 & 3.58 \\
\hline
\end{tabular}

7.2. Tritium Labeling of Nucleosides. The purified RNAs were digested with RNase A, snake venom phosphodiesterase, and alkaline phosphatase at $\mathrm{pH} 8.0,37^{\circ} \mathrm{C}$ for 6 hours into nucleosides. The digest was treated with a $2 \mathrm{X}$ molar excess of $\mathrm{NaIO}_{4}$ and labeled with $\left[{ }^{3} \mathrm{H}\right]-\mathrm{KBH}_{4}$ at $\mathrm{pH} 6$ for 2 hours in the dark to produce trialcohol derivatives of nucleosides. All nucleosides with base modifications, except 2 '-O-ribose modified, were labeled with tritium. The tritium-labeled trialcohol derivatives were separated by twodimensional TLC (thin layer chromatography) on cellulose thin layers (Figure 5) [81]. The first dimension used a solvent of acetonitrile, ethylacetate, n-butanol, isopropanol, $6 \mathrm{~N}$ aqueous ammonia $(7: 2: 1: 1: 2.7)$; the second dimension used a solvent of tert-amyl alcohol, methylethylketone, acetonitrile, ethylacetate, water, formic acid (sp.gr. 1.2) $(4: 2: 1.5: 2: 1.5: 0.18)[81,82]$. 
Presence of ESE, branch sites and splice sites in 4.5S RNA I (Novikoff)

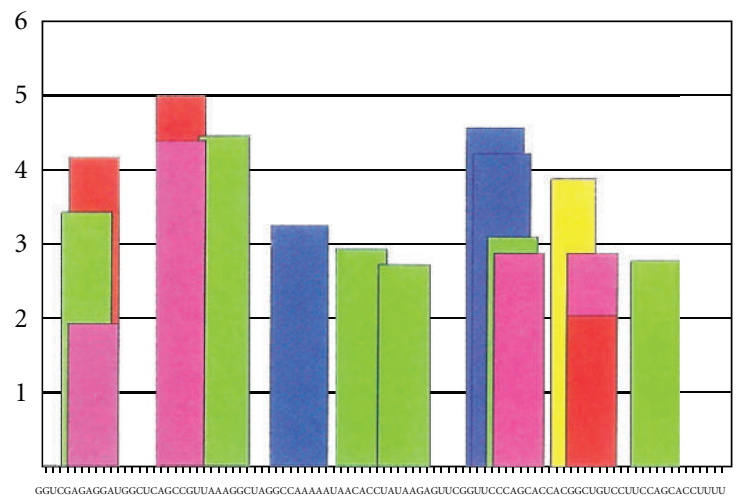

ESE in 4.5S RNA I (Novikoff)

$\begin{array}{ll}\text { ESE } & \text { Threshold } \\ \text { SF2/ASF } & 1.956 \\ \text { SF2/ASF (IgM-BRCA) } & 1.867 \\ \text { SC35 } & 2.383 \\ \text { SRp40 } & 2.67 \\ \text { SRp55 } & 2.676\end{array}$

(a)

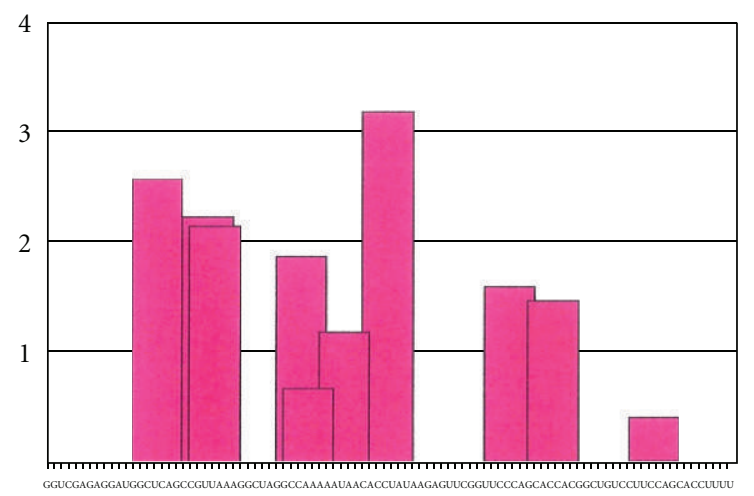

Branch sites in 4.5S RNA I (Novikoff)

Branch sites threshold 0

(b)

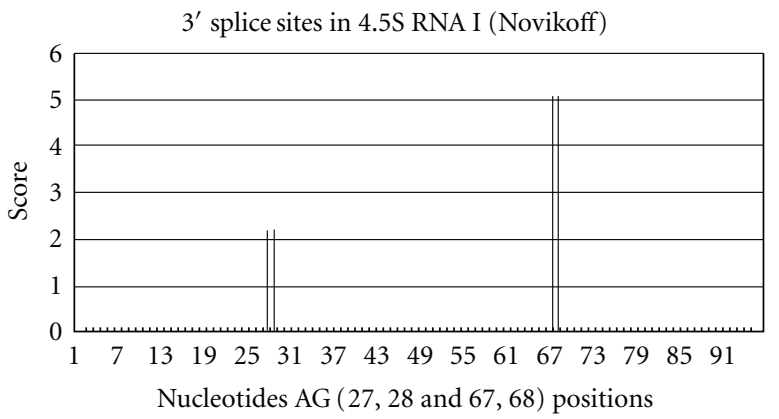

(c)

FIgURE 10: ESE motifs in 4.5S RNA. The sequences of 4.5S RNA I from Novikoff hepatoma cell nuclei were screened by ESE finder 3 [13] for ESE, 5' splice sites, branch sites, and $3^{\prime}$ splice sites. The default threshold value was used. There were 4 SF2/ASF sites, 3 SC35 sites, 6 SRp40 sites, 1 SRp55 sites, 10 branch sites, and 2 3' splice sites. These numbers resemble the number identified in Alu elements of human FMR1 transcript (Table 8).
TABLE 9: The snRNA $2^{\prime}$ and $3^{\prime}-\mathrm{OH}$ labeling by $\mathrm{NaIO}_{4}$ oxidation and $\left[{ }^{3} \mathrm{H}\right]-\mathrm{KBH}_{4}$ reduction [38]. The total $4-7 \mathrm{~S}$ RNA from rat Novikoff hepatoma cell nuclei was labeled with $\left[{ }^{3} \mathrm{H}\right]$ by oxidation with $\mathrm{NaIO}_{4}$ followed by $\left[{ }^{3} \mathrm{H}\right]-\mathrm{KBH}_{4}$ reduction (Figure 12). Individual RNA species were purified by gel electrophoresis (Figure 13). The RNA samples were hydrolyzed with $0.3 \mathrm{~N} \mathrm{KOH}$, and hydrolysates were chromatographed on whatman $3 \mathrm{MM}$ paper according to de Wachter and Fiers [55]. The radioactivities at the origin $(22 \%$ for 5 S RNA, $54.1 \%$ for U1 RNA, $49.7 \%$ for U2 RNA, and $50.6 \%$ for U3 RNA) represent \% of total radioactivity applied and they represent the $5^{\prime}$ end labeling which was later elucidated by many enzymatic methods described in the text. The radioactivities moved by chromatography with standard nucleoside derivatives are the $\%$ of total in nucleosides derivatives. The $\mathrm{A}^{\prime} \mathrm{U}^{\prime} \mathrm{G}^{\prime} \mathrm{C}^{\prime}$ represent trialcohol derivatives of nucleosides.

\begin{tabular}{lccccc}
\hline & \multicolumn{5}{c}{$3^{\prime}$ Nucleoside derivatives } \\
& $\begin{array}{c}\text { Radioactivity } \\
\text { RN origin }\left(5^{\prime}\right)\end{array}$ & $\mathrm{A}^{\prime}$ & $\mathrm{U}^{\prime}$ & $\mathrm{G}^{\prime}$ & $\mathrm{C}^{\prime}$ \\
& $\%$ & $\%$ & $\%$ & $\%$ & $\%$ \\
\hline 4S RNA & 10.9 & 89.0 & 3.2 & 3.9 & 3.8 \\
4.5S RNA & 15.8 & 11.2 & 79.7 & 4.0 & 5.1 \\
4.5S RNA I & 6.5 & 6.1 & 87.4 & 4.7 & 1.8 \\
4.5S RNA II & 30.9 & 13.1 & 80.2 & 4.7 & 2.4 \\
5S RNA & 22.0 & 11.4 & 75.5 & 6.0 & 7.0 \\
U1 RNA & 54.1 & 6.0 & 13.4 & 77.7 & 3.0 \\
U2 RNA & 49.7 & 61.5 & 6.0 & 4.3 & 28.2 \\
U3 RNA & 50.6 & 53.8 & 22.6 & 9.8 & 13.7 \\
\hline
\end{tabular}

7.3. $\left[{ }^{32} P\right]$ Labeling of RNA. The Novikoff hepatoma cells were transplanted intraperitoneally into male albino rats of the Holtzman strain weighing 200-250 g, obtained from Cheek Jones Company (Houston, Tex). After 5-6 days, the cells were harvested and washed with NKM solution $(0.13 \mathrm{M}$ $\mathrm{NaCl}, 0.005 \mathrm{M} \mathrm{KCl}$, and $0.008 \mathrm{M} \mathrm{MgCl}_{2}$ ). Twenty milliliter (packed volume) of cells was incubated with $500 \mathrm{mCi}$ of $\left[{ }^{32} \mathrm{P}\right]$-orthophosphate in 1 liter of medium (phosphate free modified Eagle's minimal essential medium) for 9-16 hours [83]. Nuclear RNA was purified by sucrose gradient centrifugation, gel electrophoresis, and column chromatography [38]. The purified RNA was hydrolyzed with $0.3 \mathrm{~N} \mathrm{KOH}$, and alkaline-resistant oligonucleotides were separated on DEAESephadex. The alkaline resistant dinucleotides were collected, treated with alkaline phosphatase, and identified by twodimensional chromatography (Figure 16).

The summary of modified nucleotides is in Table 1 [84].

\section{Structural Determination of $5^{\prime}$ Oligonucleotides}

The structures of the $5^{\prime}$ ends of U1 RNA, U2 RNA, U3 RNA, and 5S RNA III (U5) are determined by the characteristics of chemical reactions and enzymatic susceptibilities (Figure 17).

8.1. U1 RNA $5^{\prime}$ End Oligonucleotide. The U1 RNA labeled with $\left[{ }^{3} \mathrm{H}\right]$ by $\mathrm{NaIO}_{4}$ and $\left[{ }^{3} \mathrm{H}\right]-\mathrm{KBH}_{4}$, digested with RNase 
(1) Human HeLa U1A RNA (2) Rat Novikoff U1 RNA (Involved pre-mRNA splicing)

(1) $\mathrm{m}_{3}{ }^{2,2,7}$ GpppAmUmAC $\Psi$ ACCU GGCAGGGGAG AUACCAUGAU

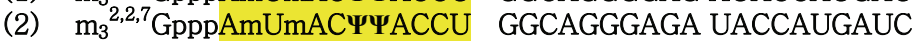

(1) CACGAAGGUG GUUUUCCCAG GGCGAGGCUU AUCCAUUGCAm CUCCGGAUGU

(2) ACGAAGGUGU UUUCUCUCCA GGGCGUGGUC UAUCCAUUGA GGCGCAmCUCC

(1) GCUGACCCCU GCGAUUUCCC CAAAUGUGGG AAACUCGACU GCAUAAUUUG

(2) GUGGAUGCUG ACCCCUGCGA UUUCCUCCAA AUGCGGGAAA CUCGACUGCA

(1) UGGUAGUGGG GGACUGCGUU CGCGCUUUCC CCUG-OH (164) [15]

(2) UAAUUUGUGG UAGUGCGGGG GACUGUUCGC GCUCCUCUCG-OH (170) [16] Pre-mRNA 5' splice site binding region Sm protein binding region

(3) Human HeLa U2 RNA (4) Rat Novikoff U2 RNA (Involved in pre-mRNA splicing)

(3) $\mathrm{m}_{3}{ }^{2,2,7}$ GpppAmUmCGCUUCUC GmGmCCUUUUGmG CUAAGmAUCAAm

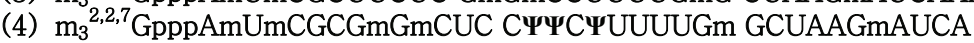

(3) GUGUAGUAUCm $\Psi$ GUUCUUAUC AGUUUAAUAU CmUGAUACGUC

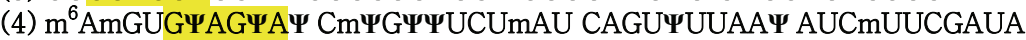

(3) CUCUAUCCGA GGACAAUAUA UUAAAUGGAU UUUUGGAGCA GGGAGAUGGA

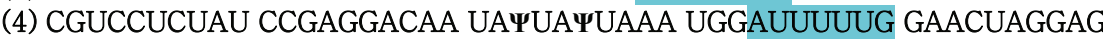

(3) AUAGGAGCUU GCUCCGUCCA CUCCACGCAU CGACCUGGUA UUGCAGUACC

(4) UUGGAAUAGG AGCUUGCUCC GUCCACCUCA CGCAUCGACC UGGUAUUGCG

(3) UCCAGGAACG GUGCACCA-OH (188) [17]

(4) CAGUACCCUC AGGAACGGUG CACCA-OH (195) [18]

Branch point binding region Sm protein binding region

(5) Human Placenta U3 RNA (6) Rat Novikoff U3B RNA (Involved in rRNA production)

(5) $\mathrm{m}_{3}{ }^{2,2,7}$ GpppAmAmGACUAUAC UUUCAGGGAU CAUUUCUAUA GUGUGUUACU

(6) $\mathrm{m}_{3}{ }^{2,2,7} \mathrm{GpppAmA}(\mathrm{m})$ AGCUAUAC UUUCAGGGAU CAUUUCUAUA GUUCGUUACU

(5) AGAGAAGUUU CUCUGAACGU GUAGAGCACC GAAAACCACG AGGAAGAGAG

(6) AGAGAAGUUU CUCUGACUGU GUAGAGCACC CGAAACCACG AGGACGAGAC

(5) GUAGCGUUUU CUCCUGAGCG UGAAGCCGGC UUUCUGGCGU UGCUUGGCUG

(6) AUAGCGUCCC CUCCUGAGCG UGAAGCCGGC UCUAGGUGCU GCUUCUGUGC

(5) CAACUGCCGU CAGCCAUUGA UGAUCGUUCU UCUCUCCGUA UUGGGGAGUG

(6) AGCUGCCUCU UGCCAUUGAU GAUCGUUCUU CUCUCCUUCG GGAGGGUAAG

(5) AGAGGGAGAG AACGCGGUCU GAGUGGU-OH (217) $[19,20]$

(6) AGGGAGGGAA CGCAGUCUGA GUGGA-OH (215) [21]

Box A Box B Box C Box D

(7) Human HeLa U4A RNA (8) Rat Novikoff U4 RNA (Involved in pre-mRNA splicing)

(7) $\mathrm{m}_{3}{ }^{2,2,7}$ GpppAmGmC$\Psi U U G C m G C$ AGUGGCAGUA UCGUAGCCAA UGAGGUUUAU

(8) $\mathrm{m}_{3}{ }^{2,2,7} \mathrm{GpppAmAC} \Psi U U G C A G$ UGGCAGUAUC GUAGCCAAUG AGGUUUAUCC

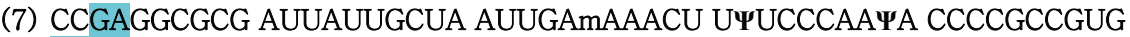

(8) GAGGCGCGAU UAUUGCUAAU UGAmAAACUUU UCCCAA $\Psi$ ACC CCGCCGUGAC

(7) ACGACUUGCA AUAUAGUCGG CAUUGGCAAU UUUUGACAGU CUCUACGGAG

(8) GACUUGAm ${ }^{6}$ AAU AUAGUCGGCA UUGGCAAUUU UUGUCUCUAC GGAGACUG

(7) $\operatorname{ACUG}(\mathrm{G})-\mathrm{OH}(144-145)[22,23]$

(8) (138) [24] 
U6 RNA binding region $15.5 \mathrm{~K}$ protein \& $\mathrm{hPrp} 31$ binding region [23]

(9) Human HeLa U5A RNA (10) Rat Novikoff U5A RNA(Involved in pre-mRNA splicing)

(9) $m_{3}^{2,2,7}$ GpppAmUmACUCUGGU UUCUCUUCAG AUCGCAUAAA UCUUUCGmCCU

(10) $m_{3}^{2,2,7}$ GpppAmUmACUCUGGU UUCUCUUCAG AUCGUAUAAA UCUUUCGmCCU

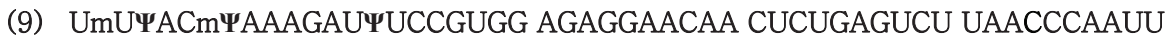

(10) UmUUAUmCAAAGAUYUCCGUGGAGAGGAACAACUCUGAGUCU UAAACCAAUU

(9) UUUUGAGCCU UGCCUUGGCA AGGCUA-OH (116) [25]

(10) UUUUGAGGCC UUGUCUUGAC AAGGCUA-OH (117) [26]

mRNA binding region in spliceosome

(11) Human Liver U6 RNA (12) Rat Novikoff U6 RNA(Involved in pre-mRNA splicing)

(11) mpppGUGCUCGCUU CGGCAGCACA UAUACUAAAA UUGGAACGAU

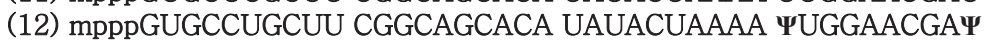

(11) $\mathrm{ACm}^{6}$ AGAGAmAGAUUAmGmCAUGGCmCCmCmUGCGCAAm Gm² GAUGACmACG

(12) $\mathrm{ACm}^{6}$ AGAGAmAGAUUAmGmCAUGGCm CCmCmUGCGCAAm Gm² GAUGACmACG

(11) CAAAUUCGUG AAGCGUUCCA UAUUUU(U)-OH (106-107) [27]

(12) CAAAUTCGUG AAGCGUUCCA UAUUUU(U)-OH (106-107) [28]

U4 RNA binding region

(13) Human HeLa U7 RNA (Involved in Histone mRNA processing)

(13) $m_{3}^{2,2,7}$ GpppNNGUGUUACA GCUCUUUUAG AAUUUGUCUA GUAGGCUUUC

(13) UGGCUUUUCA CCGGAAAGCC CCU-OH (63) [29]

Histone pre-mRNA $3^{\prime}$ end binding region Sm \& LSm protein binding region

(14) Human HeLa U8 RNA (Involved in rRNA processing)

(14) $\mathrm{m}_{3}^{2,2,7}$ GpppAUCGUCAGGU GGGAUAAUCC UUACCUGUUC CUCCUCCGGA

(14) GGGCAGAUUA GAACAUGAUG AUUGGAGAUG CAUGAAACGU GAUUAACGUC

(14) UCUGCGUAAU CAGGUCUUGC AACAUCCUGA UUGCUCCUAU CUGAUU-OH (136) [30]

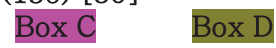

(15) Human U13 RNA (Involved in rRNA processing)

(15) $m_{3}^{2,2,7}$ GpppGAUCCUUUUG UAGUUCAUGA GCGUGAUGAU UGGGUGUUCA

(15) UACGCUUGUG UGAGAUGUGC CACCCUUGAA CCUUGUUACG ACGUGGGCAC

(15) AUUAUUCGUC UGAUC-OH (105) [30]

Box C Box D 18S rRNA binding region

(b)

FIGURE 11: Sequences of major snRNAs (see [15-30]). The sequences of major snRNAs from human and rat involved in splicing and processing are aligned for comparison. The sequence elements in major spliceosomal snRNAs and processosomal snoRNAs are highlighted in the sequences. Those are the pivotal motifs for the function. The numbers in parenthesis are the chain length of the RNAs.

A, showed enzyme-resistant oligonucleotide eluting close to the pentanucleotide region on a DEAE column (Figure 15). The $5^{\prime}$ oligonucleotide was analyzed by $\mathrm{UV},\left[{ }^{3} \mathrm{H}\right]$, and $\left[{ }^{32} \mathrm{P}\right]$ methods.

8.1.1. The UV Analysis. The $5^{\prime}$ oligonucleotides from U1 RNA, obtained by RNase A and RNase T1, were digested with snake venom phosphodiesterase and alkaline phosphatase. The nucleosides produced were separated on HPLC (high pressure liquid chromatography) [strongly basic cation exchange (quaternary amine)]. As shown in Figure 18, the amount of nucleoside ratio was 1.0, 1.2, 1.2, 0.7, and 0.9 for $\mathrm{Am}, \mathrm{A}, \mathrm{Um}, \mathrm{m}_{3}{ }^{2,2,7} \mathrm{G}$, and $\mathrm{C}$, respectively, for $\mathrm{U} 15^{\prime}$ oligonucleotide. 


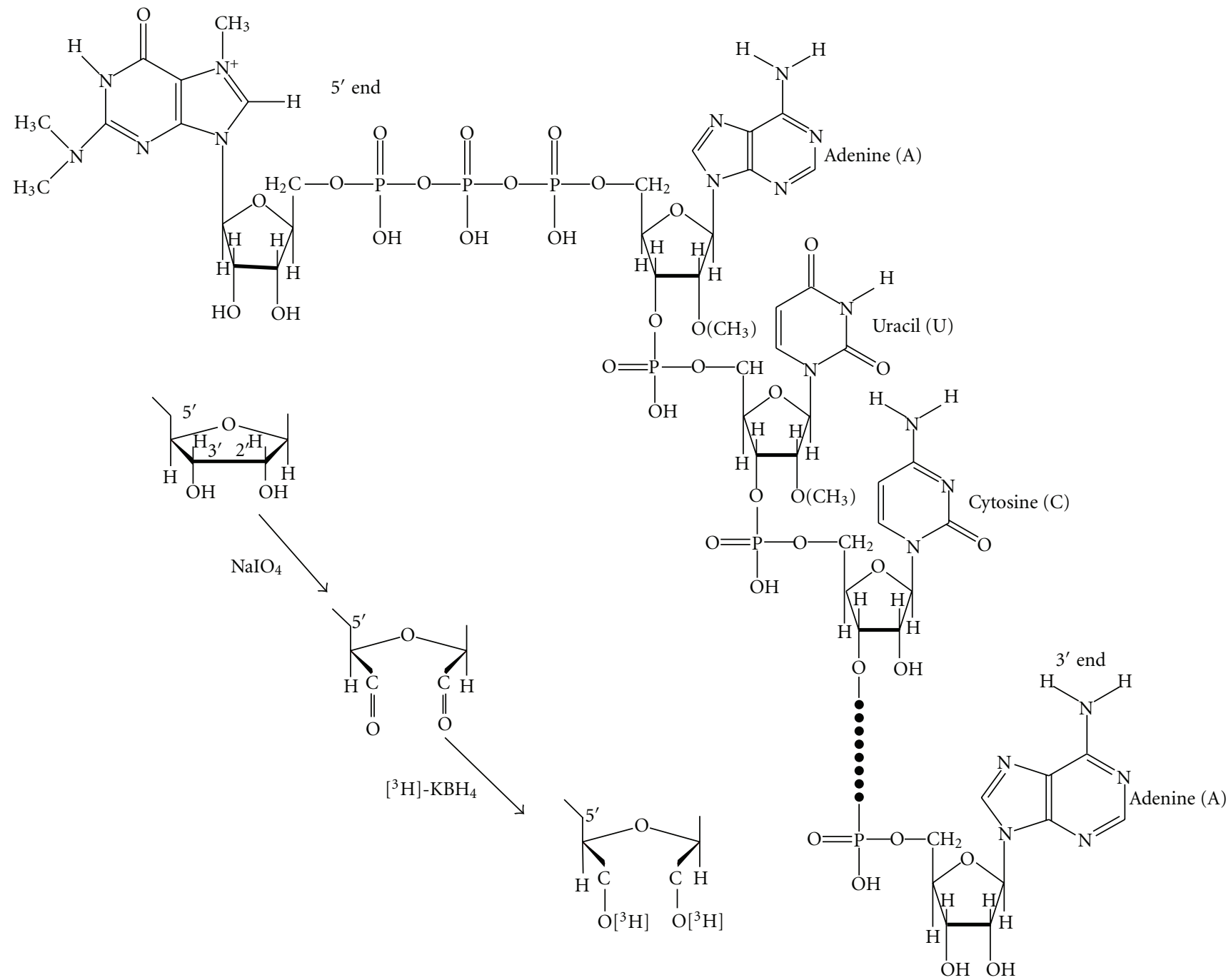

FIgURE 12: RNA $5^{\prime}$ and $3^{\prime}$ end labeling with $\left[{ }^{3} \mathrm{H}\right]$ by treatment with $\mathrm{NaIO}_{4}$ and $\left[{ }^{3} \mathrm{H}\right]-\mathrm{KBH}_{4}$. The 4-7S RNA from Novikoff hepatoma cell nuclei was labeled to detect the presence of free $2^{\prime}-\mathrm{OH}$ and $3^{\prime}-\mathrm{OH}$ by $\mathrm{NaIO}_{4}$ oxidation followed by $\left[{ }^{3} \mathrm{H}\right]-\mathrm{KBH}_{4}$ reduction. The reaction occurred at both ends of RNA ( $5^{\prime}$ end and $3^{\prime}$ end).

8.1.2. The $\left[{ }^{3} \mathrm{H}\right]$ Method. The $\left[{ }^{3} \mathrm{H}\right]$-labeled U1 RNA 5' oligonucleotide, following digestion with snake venom phosphodiesterase and alkaline phosphatase, was separated by chromatographic methods with standards. Two-dimensional TLC (thin layer chromatography) and paper chromatography demonstrated that the $\left[{ }^{3} \mathrm{H}\right]$ labeled compound is a trimethylguanosine derivative (Figure 19).

8.1.3. ${ }^{32}$ P-Labeled $5^{\prime}$ Oligonucleotide from U1 RNA. The ${ }^{32} \mathrm{P}-$ labeled RNA was digested with $\mathrm{T}_{2}$ and $\mathrm{U}_{2}$ RNase, and digestion products were separated by two-dimensional electrophoresis. The first dimension was on cellogel at $\mathrm{pH} 3.5$, and the second dimension was on DEAE paper at $\mathrm{pH} 3.5$ (Figure 20).

Spot "a" was eluted and treated with alkaline phosphatase and chromatographed with GMP, GDP, and GTP standards. The ${ }^{32}$ P-labeled $5^{\prime}$ oligonucleotide was chromatographed in the GTP region on a DEAE-Sephadex column (Figure 21).
The oligonucleotide peak from the GTP region was digested with snake venom phosphodiesterase and separated by electrophoresis in the first dimension followed by chromatography on second dimension (Figure 22).

The ${ }^{32} \mathrm{P}$ activity ratio was $1.00,1.11,1.25,0.53$, and 1.14 for $\mathrm{pm}_{3}{ }^{2,2,7} \mathrm{G}, \mathrm{pAm}, \mathrm{pUm}, \mathrm{pA}$, and $\mathrm{Pi}$, respectively. The peak from the GTP region in Figure 21 digested with RNase P1 produced pUm, pA (peak a in Figure 23), and cap core $\mathrm{m}_{3}{ }^{2,2,7} \mathrm{GpppAm}$ (peak $\mathrm{b}$ in Figure 23). Table 10 shows the radioactivity distribution in peaks a and $\mathrm{b}$ in Figure 23.

For the analysis of a number of phosphates in cap core (peak b), the cap core was treated with $\mathrm{NaIO}_{4}$ and aniline to remove $\mathrm{m}_{3}{ }^{2,2,7} \mathrm{G}$ by $\beta$-elimination reaction (Figure 24 ).

The product was chromatographed on a DEAE column with standard AMP, ADP, and ATP. The product was eluted close to ATP, indicating that it is pppAm. This experiment proved that the $5^{\prime}$ oligonucleotide structure is $\mathrm{m}_{3}{ }^{2,2,7} \mathrm{GpppAmpUmpApCp.}$ 


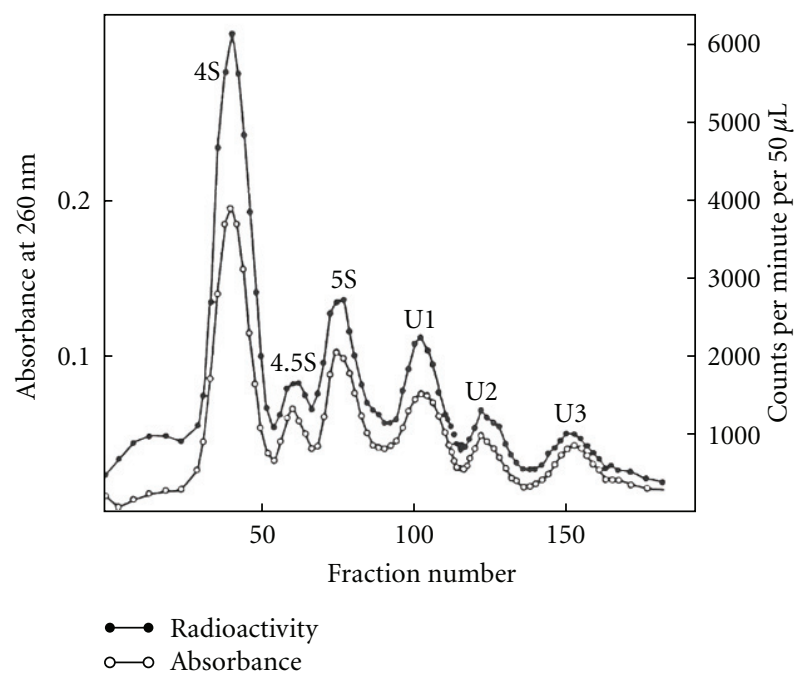

Figure 13: Preparative gel electrophoretic pattern of 4-7S RNA labeled with $\left[{ }^{3} \mathrm{H}\right][16]$. The intact, labeled RNA (as in Figure 12) was subjected to preparative polyacrylamide gel electrophoresis. The UV absorption and radioactivity were measured.

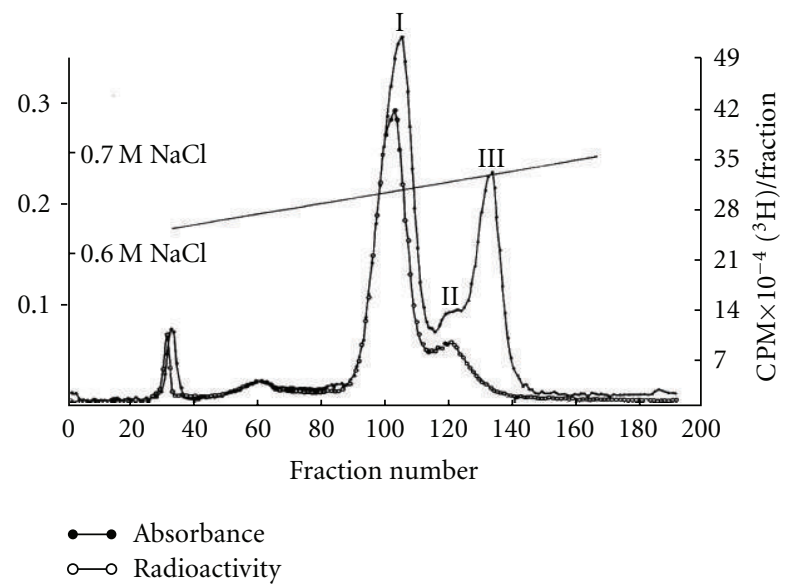

FIgURE 14: DEAE-Sephadex column chromatography of $4.5 \mathrm{~S}$ RNA [38]. The 4.5S RNA from preparative gel electrophoresis was collected and chromatographed on a DEAE-Sephadex A-50 column. It was separated into 3 peaks but no radioactivity in $4.5 \mathrm{~S}$ RNA III was detected, indicating the absence of accessible $2^{\prime}-\mathrm{OH}$ and $3^{\prime}-\mathrm{OH}$ in this molecule. The 4.5S RNA II may be the U6 RNA.

8.2. U2 RNA $5^{\prime}$ End Oligonucleotide. The U2 RNA labeled with $\mathrm{NaIO}_{4}$ and $\left[{ }^{3} \mathrm{H}\right]-\mathrm{KBH}_{4}$ was digested with RNase A. The labeled oligonucleotide eluted around the tetranucleotide region (Figure 15). The $5^{\prime}$ oligonucleotide was analyzed by $\mathrm{UV},\left[{ }^{3} \mathrm{H}\right]$, and $\left[{ }^{32} \mathrm{P}\right]$ methods.

8.2.1. UV Analysis. The $5^{\prime}$ oligonucleotide obtained by complete RNase A digestion was analyzed for its base composition. The purified $5^{\prime}$ oligonucleotide was digested with snake venom phosphodiesterase followed by alkaline phosphatase. The digestion product (nucleosides) was separated by HPLC. The composition was Am, Um, C, and $\mathrm{m}_{3}{ }^{2,2,7} \mathrm{G}$ in a ratio of

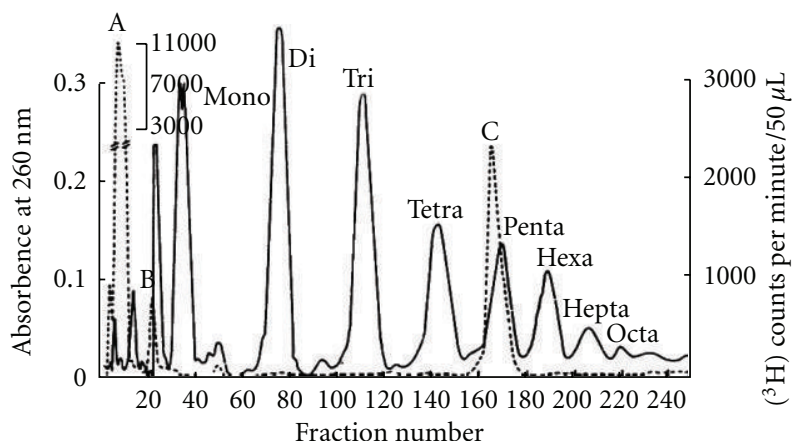

(a) U1 RNA

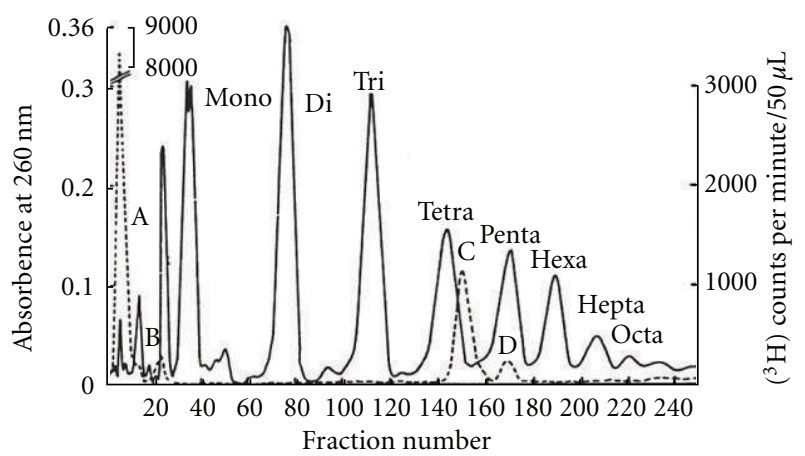

(b) U2 RNA

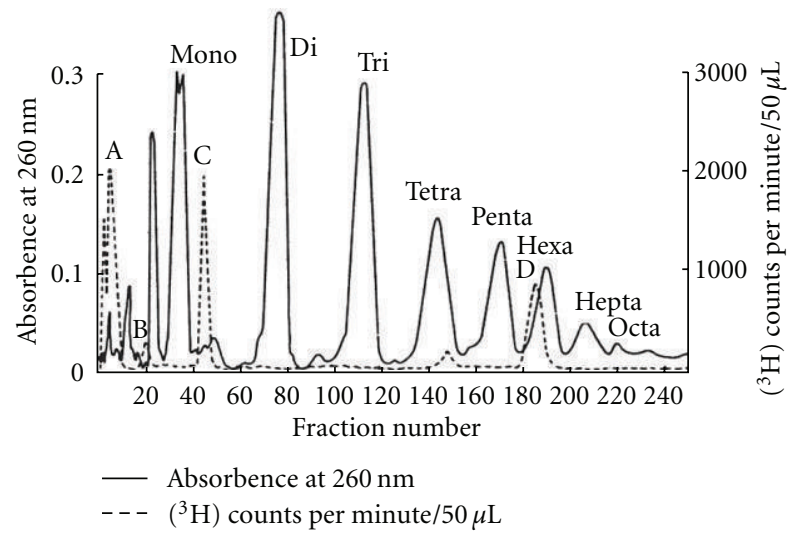

(c) U3 RNA

FIGURE 15: DEAE-Sephadex chromatography of 5' oligonucleotide [37]. The U1 RNA, U2 RNA, and U3 RNA collected from preparative gel electrophoresis (Figure 13) were digested with RNase A and subjected to DEAE-Sephadex A-25 column chromatography. The radioactive peaks at nucleoside region were coming from $3^{\prime}$ ends and the radioactivities at the regions of penta-, tetra-, and hexanucleotides were from $5^{\prime}$ end labeling. These fragments were treated with T1 RNase and found to be shortened by one nucleotide only in $U 35^{\prime}$ oligonucleotide indicating that $G$ was next to the terminal pyrimidine nucleotide.

1.0, 1.3, 1.1, and 0.96, respectively, (Figure 18) [12]. These nucleosides were also separated by two-dimensional TLC in a borate system. Um and Am migrated through the butanolboric acid while the $\mathrm{m}_{3}{ }^{2,2,7} \mathrm{G}$ and $\mathrm{C}$, which form complexes with borate, were retarded in the butanol-boric acid phase (Figure 25). 


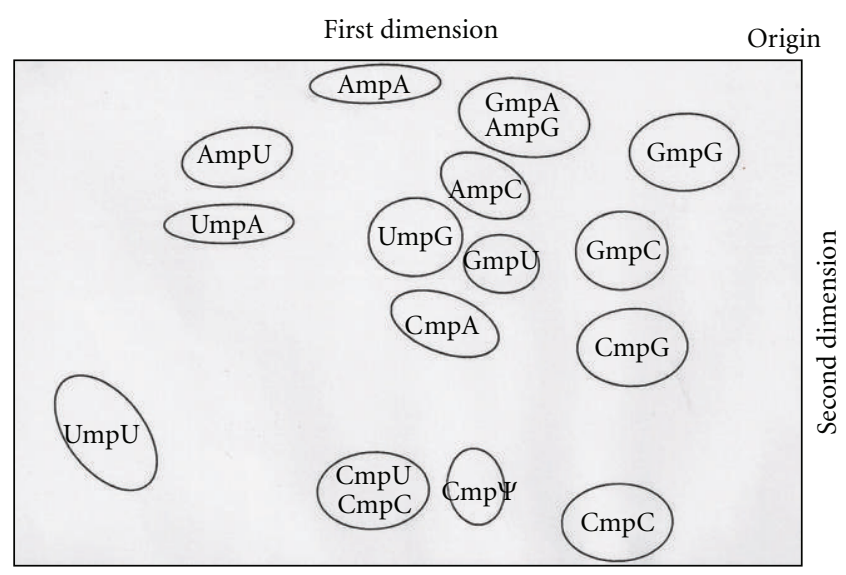

(a)

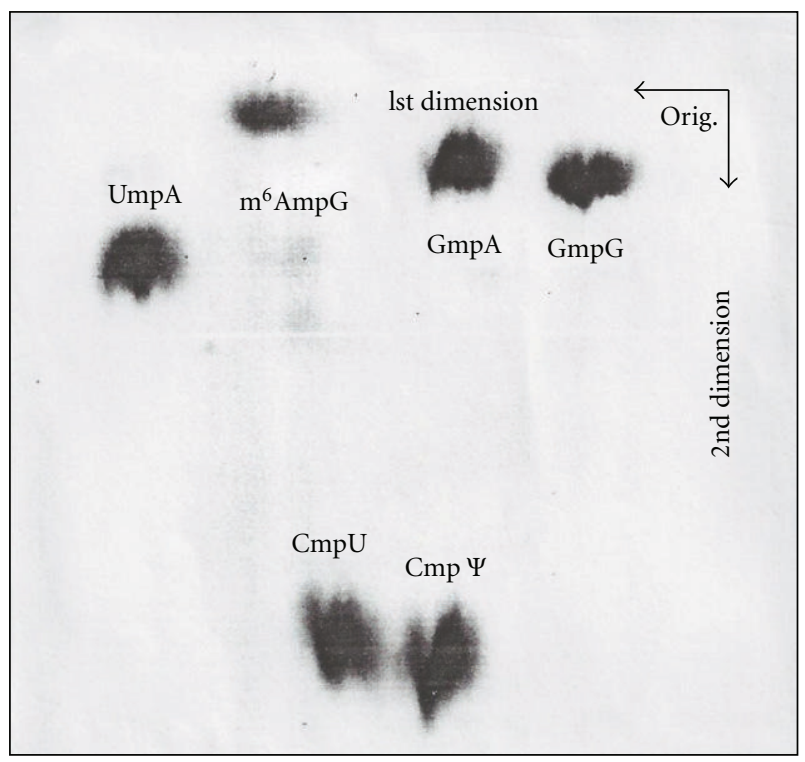

(b)

FIGURE 16: Two-dimensional separation of alkali stable dinucleoside monophosphate $[18,39]$. (a) Standard dinucleoside monophosphates $(\mathrm{NmpN})$ were separated on Whatman no.1 paper with the solvent systems ethylacetate-1-propanol-water $(4: 1: 2, \mathrm{v} / \mathrm{v})$ in the first dimension and in the second dimension with 2-propanolwater-concentrated ammonium hydroxide $(7: 2: 1, \mathrm{~V} / \mathrm{V})$. (b) Autoradiograph of two-dimensional separation of alkali-stable dinucleoside monophosphate of U2 RNA from Novikoff hepatoma cell nuclei. The $\left[{ }^{32} \mathrm{P}\right]$-labeled U2 RNA was hydrolyzed by $0.3 \mathrm{~N} \mathrm{NaOH}$, and the sample was separated on a DEAE-Sephadex column A-25 at $\mathrm{pH}$ 7.6. The dinucleotides were collected and treated with alkaline phosphatase. The alkali stable dinucleoside monophosphates were separated on Whatman no. 1 paper and autoradiographed with Xray film.

The UV spectra of $\mathrm{pm}_{3}{ }^{2,2,7} \mathrm{G}$ were typical of a trimethyl $\mathrm{G}$ nucleotide (Figure 8). The mass spectrometry of the unknown nucleoside from U2 RNA 5' fragment was identified as $m_{3}^{2,2,7}$ trimethylguanosine (Figure 9).

8.2.2. $\left[{ }^{3} \mathrm{H}\right]$-Labeled U2 RNA 5' Oligonucleotide. The purified U2 RNA, labeled with $\mathrm{NaIO}_{4}$ and $\left[{ }^{3} \mathrm{H}\right]-\mathrm{KBH}_{4}$ methods, was
TABLE 10: The $\left[{ }^{32} \mathrm{P}\right] \mathrm{cpm}$ radioactivity distribution in nucleotides and cap core produced by RNase P1 digestion of U1 5' oligonucleotide [16]. The $\left[{ }^{32} \mathrm{P}\right.$ ]-labeled U1 5' oligonucleotide obtained by digestion of U1 RNA with RNase T2, RNase U2, and alkaline phosphatase was treated with $\mathrm{P}_{1}$ nuclease which cleaves all phosphodiester bonds but not pyrophosphate bonds. The products were separated on a DEAE column (Figure 23). The radioactivity in peak a (mononucleotides $\mathrm{pUm}, \mathrm{pA}$ ) and peak $\mathrm{b}$ (cap core $\mathrm{m}_{3}{ }^{2,2,7} \mathrm{GpppAm}$ ) were determined by Packard liquid scintillation spectrometer.

\begin{tabular}{lcc}
\hline & Peak a $(\mathrm{pUm}, \mathrm{pA})$ & Peak b $\left(\mathrm{m}_{3}^{2,2,7} \mathrm{GpppAm}\right)$ \\
\hline U1 5 $^{\prime}$ cap & 65,280 & 87,600 \\
\hline
\end{tabular}

digested with RNase A and 5' oligonucleotide purified by DEAE-Sephadex column chromatography (Figure 15). The purified 5 ' oligonucleotide was digested with snake venom phosphodiesterase followed by alkaline phosphatase. The nucleosides obtained were separated on two-dimensional TLC [12] and 3MM paper chromatography. The tritiumlabeled compound was identified as a trialcohol derivative of $\mathrm{m}_{3}{ }^{2,2,7} \mathrm{G}$ (Figure 26).

8.2.3. [ $\left.{ }^{32} \mathrm{P}\right]$-Labeled U2 RNA $5^{\prime}$ Oligonucleotide. The $\left[{ }^{32} \mathrm{P}\right]-$ labeled U2 RNA was digested with $\mathrm{T}_{1}$ RNase or RNase A. Half of each $5^{\prime}$ oligonucleotide was digested with alkaline phosphatase. Oligonucleotides were subsequently digested with snake venom phosphodiesterase, and the resulting $5^{\prime}$ nucleotides were separated first by electrophoresis and second by chromatography (Figure 27 ). The ratio of $\left[{ }^{32} \mathrm{P}\right]$ counts is shown in Table 11.

The U2 RNA 5' oligonucleotide obtained by RNase A was subjected to digestion with pyrophosphatase (Crotalus adamanteus venom type II, Sigma). The remaining oligonucleotide did not have $m_{3}{ }^{2,2,7} \mathrm{G}$, indicating that the $\mathrm{m}_{3}{ }^{2,2,7} \mathrm{G}$ is linked by pyrophosphate linkage (Figure 28).

From these data the $5^{\prime}$ end oligonucleotide from U2 RNA has been deduced to be $\mathbf{m}_{3}{ }^{2,2,7} \mathrm{GpppAmpUmpCpGp}$.

8.3. U3 RNA $5^{\prime}$ End Oligonucleotide. The $\left[{ }^{3} \mathrm{H}\right]$-labeled U3 RNA was digested with RNase $A$ and or $T_{1}$ RNase. The $\left[{ }^{3} \mathrm{H}\right]-$ labeled $5^{\prime}$ oligonucleotide obtained by RNase A digestion was eluted in the hexanucleotide region (Figure 15). The $\left[{ }^{32} \mathrm{P}\right]$-labeled U3 RNA digested with $\mathrm{T}_{2}$ and $\mathrm{U}_{2}$ RNA produced 2 spots that were separated by two-dimensional electrophoresis (Figure 29).

8.3.1. UV Analysis. The $5^{\prime}$ oligonucleotide obtained from U3 RNA by digestion with RNase $A$ and $T_{1}$ RNase was isolated by column chromatography. The purified $5^{\prime}$ oligonucleotide was digested with snake venom phosphodiesterase and alkaline phosphatase. The nucleosides obtained were subjected to HPLC. The molar ratios of $\mathrm{m}_{3}{ }^{2,2,7} \mathrm{G}, \mathrm{Am}, \mathrm{A}$, and $\mathrm{G}$ were 1.0, 1.7, 1.1, and 1.0, respectively (Figure 18).

8.3.2. $\left[{ }^{3} \mathrm{H}\right]$ Analysis. The intact U3 RNA, labeled with $\mathrm{NaIO}_{4}$ and $\left[{ }^{3} \mathrm{H}\right]-\mathrm{KBH}_{4}$ methods, was digested with RNase A and 


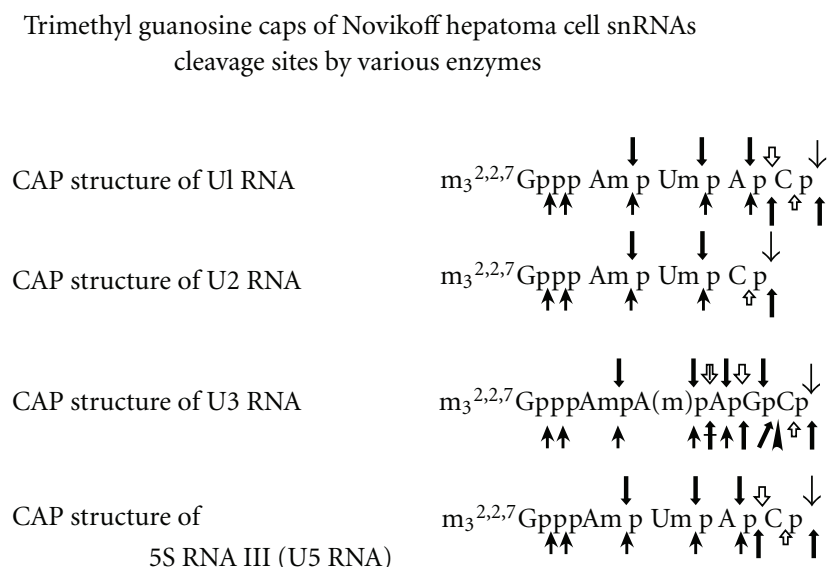

Nucleases

T1 RNase

$\downarrow$ Pl nuclease

$\uparrow$ Snake venom phosphodiesterase

$\uparrow$ T2 RNase

§ु U2 RNase

$\downarrow$ RNase A

ثิ Bacterial alkaline phosphatase

FIgURE 17: Characterization of $\mathrm{m}_{3}^{2,2,7} \mathrm{G}$ caps of snRNAs U1, U2, U3, and U5. The enzyme susceptible bonds are indicated with arrows. The split arrows indicate that some bonds without $2^{\prime}$-O-methylation can be cleaved but the ones with $2^{\prime}$-O-methylated ribose are not.

TABLE 11: The analysis of $\left[{ }^{32} \mathrm{P}\right]$-labeled U2 RNA $5^{\prime}$ oligonucleotide [12]. The $5^{\prime}$ ends obtained from uniformly [ $\left.{ }^{32} \mathrm{P}\right]$-labeled U2 RNA were digested with T1 RNase or RNase A and isolated by two-dimensional electrophoresis (cellulose acetate at pH 3.5 followed by DEAE paper electrophoresis). The $5^{\prime}$ oligonucleotides were digested with snake venom phosphodiesterase before and after removal of $3^{\prime}$ phosphate with bacterial alkaline phosphatase. The products were separated as in Figure 27. The radioactivity ratios are listed.

\begin{tabular}{|c|c|c|c|c|c|c|c|c|}
\hline \multirow{2}{*}{$5^{\prime}$ fragment from U2 RNA } & \multicolumn{8}{|c|}{${ }^{32} \mathrm{P}$ ratio in nucleotide } \\
\hline & $\mathrm{Pi}$ & pUm & pAm & $\mathrm{pm}_{3}{ }^{2,2,7} \mathrm{G}$ & $\mathrm{pC}$ & $\mathrm{pCp}$ & pG & pGp \\
\hline $5^{\prime}$ oligo from $\mathrm{T}_{1}$ digestion & 1.58 & 1.33 & 0.91 & 0.90 & 1 & & & 1.48 \\
\hline Alkaline phosphatase digested $\mathrm{T}_{1} 5^{\prime}$ oligo & 1.22 & 1.43 & 0.98 & 0.90 & 1 & & 0.93 & \\
\hline $5^{\prime}$ oligo from RNase A digestion & 1.74 & 1.25 & 1 & 1.08 & & 1.50 & & \\
\hline Alkaline phosphatase digested A 5' oligo & 0.93 & 1.45 & 0.94 & 0.77 & 1 & & & \\
\hline
\end{tabular}

chromatographed on DEAE-Sephadex (Figure 15). Subsequent digestion by $\mathrm{T}_{1}$ RNase released only one nucleotide from the RNase A oligonucleotide, indicating that the $\mathrm{G}$ was adjacent to a RNase A susceptible pyrimidine. The purified $5^{\prime}$ oligonucleotide obtained after $\mathrm{T}_{1}$ RNase and RNase A was digested with snake venom phosphodiesterase followed by alkaline phosphatase. The nucleosides and trialcohol derivatives were separated by TLC (Figure 30). The trialcohol derivative of $\mathrm{m}_{3}{ }^{2,2,7} \mathrm{G}$ indicates that this nucleotide has free $2^{\prime}$ and $3^{\prime} \mathrm{OH}$ at the end of the intact molecule.

8.3.3. $\left[{ }^{32} \mathrm{P}\right]$ Analysis. The $\left[{ }^{32} \mathrm{P}\right]$-labeled U3 RNA digested by $\mathrm{T}_{1}$ RNase and $\mathrm{U}_{2}$ RNase was separated by two-dimensional electrophoresis (Figure 29). The enzyme-resistant oligonu- cleotides $11 \mathrm{~A}$ and $11 \mathrm{~B}$ were eluted from the paper and treated with alkaline phosphatase. The products were chromatographed on DEAE-Sephadex A-25 with GMP, GDP, and GTP markers. The 11A (cap II) was eluted at GTP region and $11 \mathrm{~B}$ (cap I) was eluted at GDP region, indicating that $11 \mathrm{~B}$ has one nucleotide less than 11A (Figure 31).

From these data, obtained by UV, $\left[{ }^{3} \mathrm{H}\right]$, and $\left[{ }^{32} \mathrm{P}\right]$ experiments, the U3 RNA $5^{\prime}$ oligonucleotide sequence has been deduced to be $\mathbf{m}_{3}{ }^{2,2,7} \mathrm{GpppAmpA}(\mathrm{m}) \mathrm{pApGpCp}$.

8.4. 5S RNA III (U5 RNA) 5' End Oligonucleotide. The oligonucleotide sequence was deduced as in the case of U1 RNA. The structure is identical to the U1 $5^{\prime}$ oligonucleotide $\mathrm{m}_{3}{ }^{2,2,7} \mathrm{GpppAmpUmpApCp}$. 
TABLE 12: Tgs1 interacting proteins [70-72]. The Tgs1 (trimethylguanosine synthase 1) interacting proteins are listed. It is interacting with proteins involved in many aspects of RNA metabolism such as transcription, spliceosome assembly, maturation, and modification.

Tgs interacting proteins [70]

Transcription apparatus (regulators of RNA polymerase II transcription)

(1) Rpn4 (TF; Proteasome subunits and U2 snRNA gene)

(2) Spt3 (SAGA complex)

(3) Srb2 (mediator complex)

(4) Soh1 (Med31; mediator complex)

(5) Swr1 (ATPase; binds to $5^{\prime}$ end of yeast transcription units)

(6) Htz1(H2AZ) (binds to $5^{\prime}$ end of yeast transcription units)

(7) CBP (binds to human PIMT/Tgs1)

(8) P300 (binds to PIMT/Tgs1)

(9) PBP (binds to PIMT/Tgs1)

(10) PRIP (binds to PIMT/Tgs1; [71])

RNA end processing and decay

(1) Trf4 (Pap2; catalytic subunit of TRAMP)

(2) Lsm1 (decapping complex)

(3) Pat1 (decapping complex)
Spliceosome assembly

(1) Mud1 (yeast homolog of U1A)

(2) Mud2 (yeast homolog of U2AF65)

(3) Nam8 (Mud15) (homolog of TIA-1)

(4) Brr1 (snRNP)

(5) Lea1 (U2A; U2snRNP)

(6) Ist3 (Snu17; U2 snRNP)

(7) Isy1 (Ntc30; interacts with Prp19)

(8) Cwc21 (component of Cef1 complex)

(9) Bud13 (Cwc26) (Cef1 complex)

(10) SMN (HeLa cell) [72]

RNA modifying factors

(1) SmB (snRNP; interacts with

YNL187/Swt21)

(2) SmDL (snRNP)

(3) Cbf5 (snoRNP)

(4) Nop58 (snoRNP)

(5) Mrm (RNA 2'-O-methyltransferase)

\section{RNA Signature Modifications for Different RNA Classes}

\subsection{End Modifications}

\subsubsection{5' End}

\section{(a) According to Chemical Nature of Caps}

5' Trimethylguanosine cap for the snRNA,

5' 7-mehtylguanosine cap for the mRNA,

5' 2,7 dimethylguanosine cap of virus and nematode RNAs

5' mpppG of U6 RNA.

(b) According to Flanking Nucleotide Modification of Caps. (See Table 13).

(c) 5' End Uncapped RNA. (pppNp) for primary transcripts such as 4.5S RNA I, 5S RNA, and Alu RNA. (pNp) 5' end for processed RNAs such as Alu RNA, 5S RNA, tRNA, YRNA.

\subsection{2. $3^{\prime}$ End}

3'2'-O-methylated; 4.5S RNA III

3 ' poly-A; mRNA, lncRNA

$3^{\prime}$ poly-U; polymerase III transcripts such as $4.5 \mathrm{~S}$

RNA I, 5S RNA, and others

3' CCA; tRNA, U2 RNA.
9.2. Internal Modifications. The most colorful modifications are in tRNAs that contain methyl, formyl, acetyl, isopentyl, threonyl, carbamoyl, and other groups and modifications by pseudouridylation, deamination, reduction, or thiolation. Focusing on recent findings for snRNA, $\mathrm{m}_{3}{ }^{2,2,7} \mathrm{G}$ capping reactions are very interesting because trimethylguanosine is found only in noncoding RNA cap structures, although some nematode mRNA species also contain $\mathrm{m}_{3}{ }^{2,2,7} \mathrm{G}$ caps. The snRNAs are less abundant $\left(10^{5}\right.$ copies) than ribosomal RNA or tRNA ( $10^{6}$ copies). Isolating large amount of RNA can be a hurdle to overcome. Massive preparative procedures and syntheses were pivotal for the thorough analysis of these modifications. The 2'-O-modifications occur mostly internally, and 3' Um was also found in 4.5S RNA III. The RNA ribose with $2^{\prime}$-O-methylation confers resistance to enzymatic digestion by such enzymes as RNase $A, R$ Nase $T_{1}$, RNase $U_{2}$, and RNase $\mathrm{T}_{2}$. They are also resistant to alkaline hydrolysis, and the alkaline hydrolysates can be separated into di-, tri-, and tetranucleotides by column chromatography and then by two-dimensional paper chromatography (Figure 16). Other enzymes which can cleave 2'-O-methylated nucleotides are snake venom phosphodiesterase, P1 nuclease, and spleen phosphodiesterase. These are valuable tools for sequencing.

\section{Presence of $\mathbf{m}_{3}{ }^{2,2,7} \mathrm{G}$ Caps in RNA Species}

10.1. Nucleolar RNA. Initially, the $\mathrm{m}_{3}^{2,2,7} \mathrm{G}$ cap containing snoRNA was found in U3 RNA [36]. Since then C/D snoRNA and H/ACA snoRNA have been discovered exponentially. The snoRNAs are transcribed from monocistronic as well 

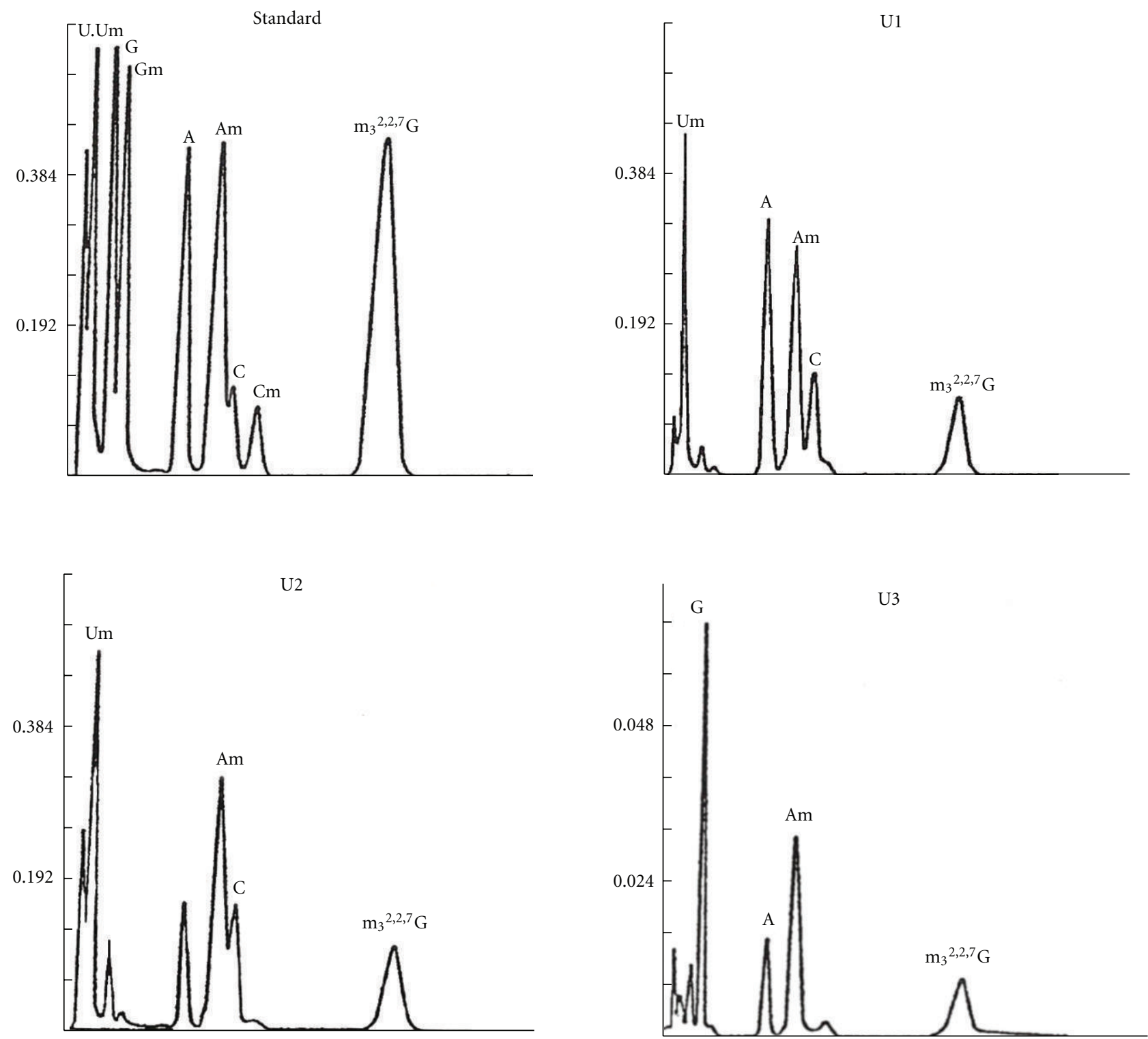

FIgURE 18: HPLC (High Pressure Liquid Chromatography) pattern of nucleosides of $5^{\prime}$ oligonucleotides of U1 RNA, U2 RNA, and U3 RNA [37]. The 5' oligonucleotides of U1, U2, and U3 RNAs were obtained by digestion of $\mathrm{T}_{1}$ RNase and RNase A. The fragments were digested with snake venom phosphodiesterase and alkaline phosphatase. The nucleosides produced were separated by high pressure liquid chromatography (Varian Aerograph Liquid Chromatograph LCS-1000) at 55 C, 700-800 p.s.i. with $0.4 \mathrm{M}$ ammonium formate (pH 3.5). Absorbance at $254 \mathrm{~nm}$ was recorded.

as polycistronic independent positions as well as intronic regions of mRNA, especially the genes coding ribosomal proteins. In vertebrates, there have been $>76$ snoRNAs that have been reported, but only U3, U8, and U13 snoRNAs have been reported to have $\mathrm{m}_{3}{ }^{2,2,7} \mathrm{G}$ caps $[33,88]$. In yeast, there are at least $17 \mathrm{~m}_{3}^{2,2,7} \mathrm{G}$ cap containing snoRNAs out of more than 76 snoRNAs. It was also reported that some snoRNA precursors, such as pre-snoRNAs 50, 64, and 69, have the $\mathrm{m}_{3}{ }^{2,2,7} \mathrm{G}$ cap, but mature snoRNA 50, 64, and 69 do not have $\mathrm{m}_{3}{ }^{2,2,7} \mathrm{G}$ caps. The maturation process cleaves the $5^{\prime}$ fragment by Rntl (RNase III like enzyme), and trimming is performed by $5^{\prime} \rightarrow 3^{\prime}$ exonuclease Xrn1 and Rat 1 [89].
10.2. Spliceosomal snRNAs. These include U1, U2, U4, U5, and U6 snRNAs. All of these except $\mathrm{U} 6$ contain the $\mathrm{m}_{3}{ }^{2,2,7} \mathrm{G}$ cap, and U6 has the mpppG cap instead. They are present in complexes as RNP with proteins specific for each RNA as well as some common snRNP proteins such as the Sm proteins. Functionally, U1 RNP acts at $5^{\prime}$ splice sites and U2 RNA at branch sites including $3^{\prime}$ splice sites. U4, U5, and U6 snRNAs enter the spliceosomal intermediate as a tri-snRNP complex.

10.3. Human Telomerase RNA (hTR). Human telomerase RNA has a structure containing the H/ACA motif with 8 conserved regions (CR 1-8) [92].The CR7 contains the CAB 
TABLE 13: Cap variations of flanking nucleotide modifications.

\begin{tabular}{lll}
\hline & Trimethylguanosine cap & 7-Methylguanosine cap \\
\hline Type 0 & $\mathrm{m}_{3}^{2,2,7} \mathrm{GpppN}-$ & $\mathrm{m}^{7} \mathrm{GpppN}-$ \\
Type I & $\mathrm{m}_{3}^{2,2,7} \mathrm{GpppNmN-}$ & $\mathrm{m}^{7} \mathrm{GpppNmN-}$ \\
Type II & $\mathrm{m}_{3}^{2,2,7} \mathrm{GpppNmNmN-}$ & $\mathrm{m}^{7} \mathrm{GpppNmNmN-}$ \\
Type III & $\mathrm{m}_{3}^{2,2,7} \mathrm{GpppNmNmNmN-}$ & $\mathrm{m}^{7} \mathrm{GpppNmNmNmN-}$ \\
Type IV & $\mathrm{m}_{3}{ }^{2,2,7} \mathrm{GpppNmNmNmNmN-}$ & $\mathrm{m}^{7} \mathrm{GpppNmNmNmNmN-}$ \\
\hline
\end{tabular}

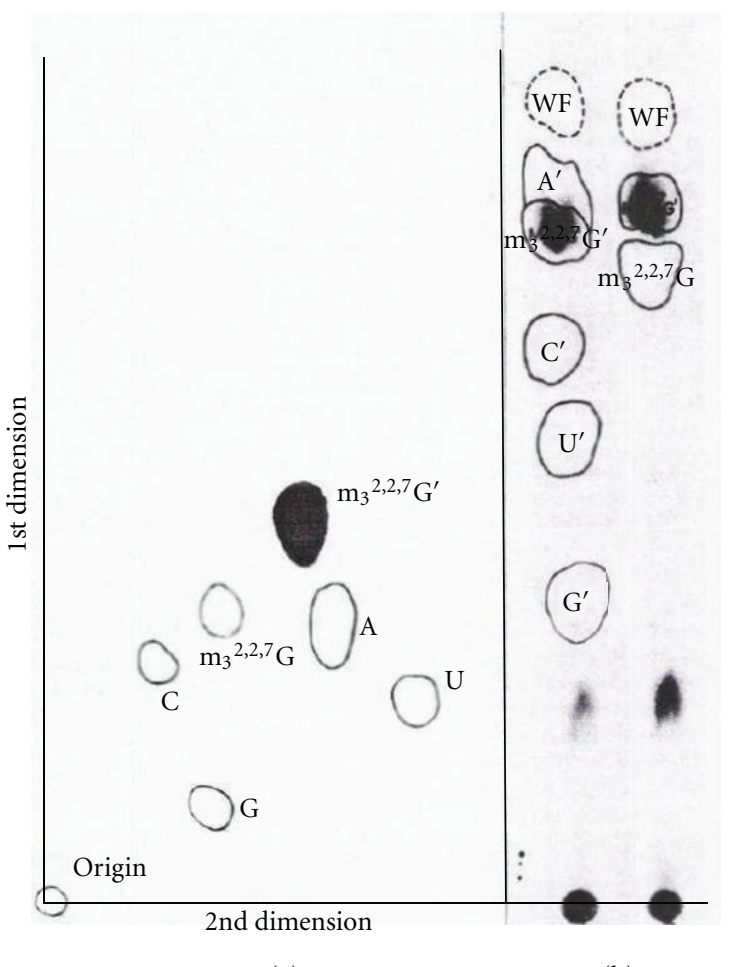

(a)

(b)

Figure 19: Identification of $\mathrm{m}_{3}^{2,2,7} \mathrm{G}^{\prime}$ [16]. (a) Fluorogram of twodimensional thin layer chromatography of $\left[{ }^{3} \mathrm{H}\right]$-labeled nucleoside trialcohol derivative $\left(\mathrm{N}^{\prime}\right)$ released from U1 RNA 5' fragment. It was identified as $\mathrm{m}_{3}{ }^{2,2,7} \mathrm{G}^{\prime}$ with standard. (b) Fluorogram of chromatographic separation of $\left[{ }^{3} \mathrm{H}\right]$-labeled nucleoside trialcohol derivative on Whatman $3 \mathrm{MM}$ paper. The $\left[{ }^{3} \mathrm{H}\right]$-labeled compound was identified as $\mathrm{m}_{3}{ }^{2,2,7} \mathrm{G}^{\prime}$ with standard.

box (Cajal body box) consensus sequence of UGAG and directs the RNA localization into the CB (Cajal body). The Tgs1 (trimethyl guanosine synthase) is also present in the Cajal body and may be responsible for the $\mathrm{m}_{3}{ }^{2,2,7} \mathrm{G}$ cap formation. Not all Cajal bodies contain the hTR, and it may be a transient localization for the maturation of hTR in the Cajal body. In the absence of Tgs1, the telomere of yeast $S$. cerevisiae has elongated single-stranded $3^{\prime}$ overhangs and TLC1 (1200 nt telomerase RNA) lacks the $\mathrm{m}_{3}^{2,2,7} \mathrm{G}$ cap. The absence of Tgs 1 causes premature aging of yeast $[93,94]$.

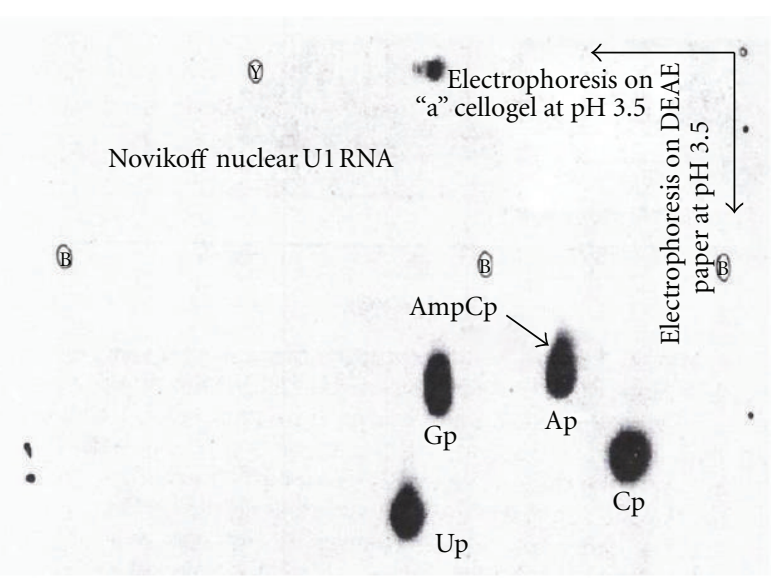

Figure 20: $2 \mathrm{D}$ map of U1 RNA digested with $\mathrm{T}_{2}$ RNase and $\mathrm{U}_{2}$ RNase [16]. The U1 RNA uniformly labeled with $\left[{ }^{32} \mathrm{P}\right]$ was digested with $T_{2}$ RNase and $U_{2}$ RNase. The resistant 5 ' fragment (spot "a") was separated from the rest of the hydrolysate by two-dimensional electrophoresis. The first dimension was on cellogel at $\mathrm{pH} 3.5$, and the second dimension was on DEAE paper in $5 \%$ acetic acid- $\mathrm{NH}_{4}$ acetate at $\mathrm{pH} 3.5$.

10.4. C. elegans SL RNA. C. elegans has mRNA with the $\mathrm{m}^{7} \mathrm{G}$ cap as well as $\mathrm{m}_{3}{ }^{2,2,7} \mathrm{G}$ cap, and the expression is regulated differentially. The genes for protein coding are monocistronic as well as polycistronic, and introns are much smaller than observed in mammalian cells. The polycistronic genes contain 2-8 operonic genes regulated by the same promoters. Some gene products are not processed, and others are spliced by cis-splicing as well as transsplicing. The transsplicings are carried out by SL RNA 1 or SL RNA 2. The approximately 110 SL RNA 1 genes are in tandem in chromosome V. The SL RNA 2 is derived from SL RNA 1 and there are $\sim 18$ dispersed genes with a variety of variant SL2 RNAs (some are called SL3, SL4, etc.). They are all 100-110 nucleotide long and contain $\mathrm{m}_{3}{ }^{2,2,7} \mathrm{G}$ caps and Sm protein binding sites. These pre-mRNAs, containing $5^{\prime}$ outron (monocistronic and $5^{\prime}$ first gene in polycistronic operonic genes), are transspliced by SL RNA 1 and internal operonic pre-mRNAs are mostly transspliced by SL RNA 2 and these genes have typically U-rich sequence containing $\sim 100$ bp spacers between two cleavage sites. The internal 


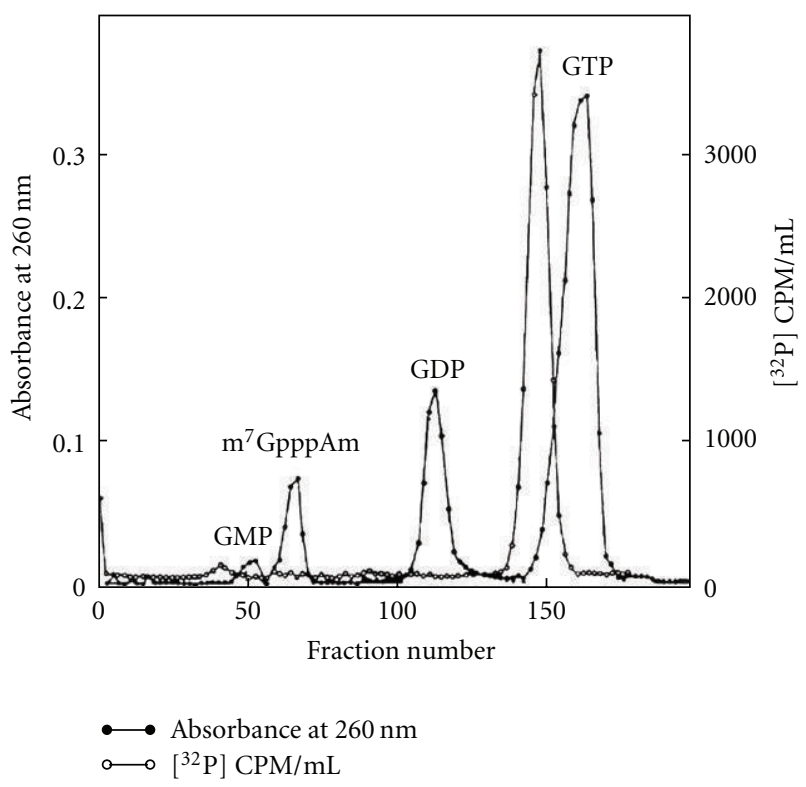

Figure 21: DEAE column chromatography of U1 5 ' oligonucleotide [16]. Spot "a" in Figure 20 was eluted and digested with alkaline phosphatase. The product was chromatographed on DEAE-Sephadex A-25 with GMP, GDP, and GTP. The fragment chromatographed at GTP region.

mRNA gene of polycistronic operonic genes, lacking a spacer, is transspliced always by SL RNA I $[95,96]$. The transspliced mRNA contains a $\mathrm{m}_{3}{ }^{2,2,7} \mathrm{G}$ cap containing 22 nucleotides of SL RNA at their $5^{\prime}$ ends. The SL RNA (splice leader RNA) has a $\mathrm{m}_{3}{ }^{2,2,7} \mathrm{G}$ cap and $\mathrm{Sm}$ protein binding sites. The nematode C. elegans has 5 eIF4E isoforms of cap binding proteins. They are IFE- $1\left(\mathrm{~m}^{7} \mathrm{G}\right.$ cap and $\mathrm{m}_{3}{ }^{2,2,7} \mathrm{G}$ cap binding), IFE-2 $\left(\mathrm{m}^{7} \mathrm{G}\right.$ cap binding, but competed by the $\mathrm{m}_{3}{ }^{2,2,7} \mathrm{G}$ cap), IFE-3 $\left(\mathrm{m}^{7} \mathrm{G}\right.$ cap binding only), IFE-4 ( $\mathrm{m}^{7} \mathrm{G}$ cap binding only), and IFE5 ( $\mathrm{m}^{7} \mathrm{G}$ cap and $\mathrm{m}_{3}{ }^{2,2,7} \mathrm{G}$ cap binding). The homolog amino acids W56 and W102 stacking the $\mathrm{m}^{7} \mathrm{G}$ caps in mice eIF4E are W51 and W97 in IFE-3 and W28 and W74 in IFE-5 (Figure 32).

The differences in 3-4 loop configuration between IFE5 and IFE-3 are N64Y/V65L. The changes in IFE-5 amino acid asparagine 64 to tyrosine and valine 65 to leucine change binding properties more to $\mathrm{m}^{7} \mathrm{G}$ cap binding than to $\mathrm{m}_{3}{ }^{2,2,7} \mathrm{G}$ cap binding. IFE- 5 has 4 cysteines, and its conformation is governed by disulfide bond formation. It is suggested that the cap binding cavity is altered to produce a smaller cavity that discriminates against the $\mathrm{m}_{3}{ }^{2,2,7} \mathrm{G}$ cap binding [85]. These may provide translational regulation of $\mathrm{m} 7 \mathrm{G}$ cap mRNA and transspliced $\mathrm{m}_{3}{ }^{2,2,7} \mathrm{G}$ cap mRNA in C. elegans.

\section{Synthesis of $\mathbf{m}_{3}{ }^{2,2,7} \mathbf{G}$ Cap}

modifications. Trimethyl $G$ caps are present in snRNAs involved in splicing and also in snoRNA involved in rRNA processing and modifications such as $\Psi$ formation

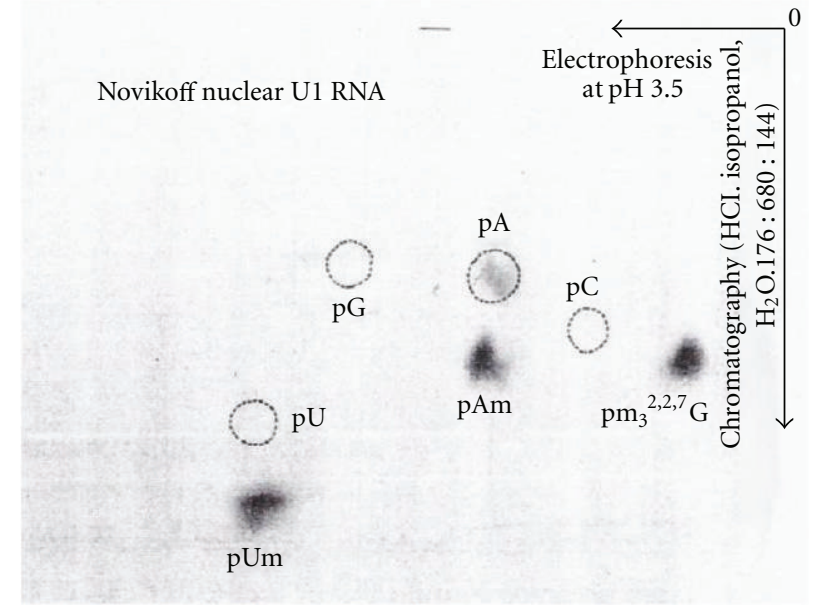

FIGURE 22: Nucleotide composition of U1 5' oligonucleotide [16]. The peak from the GTP region was digested with snake venom phosphodiesterase and separated on Whatman 3MM paper by electrophoresis at $\mathrm{pH} 3.5$ (5\% acetic acid adjusted $\mathrm{pH}$ to 3.5 with ammonium hydroxide) and chromatography in the second dimension with a solvent system consisting of isopropyl alcohol, $\mathrm{HCl}$, and $\mathrm{H}_{2} \mathrm{O}$ in the ratio of $680: 176: 144$ by volume. Autoradiography was performed using X-ray film.

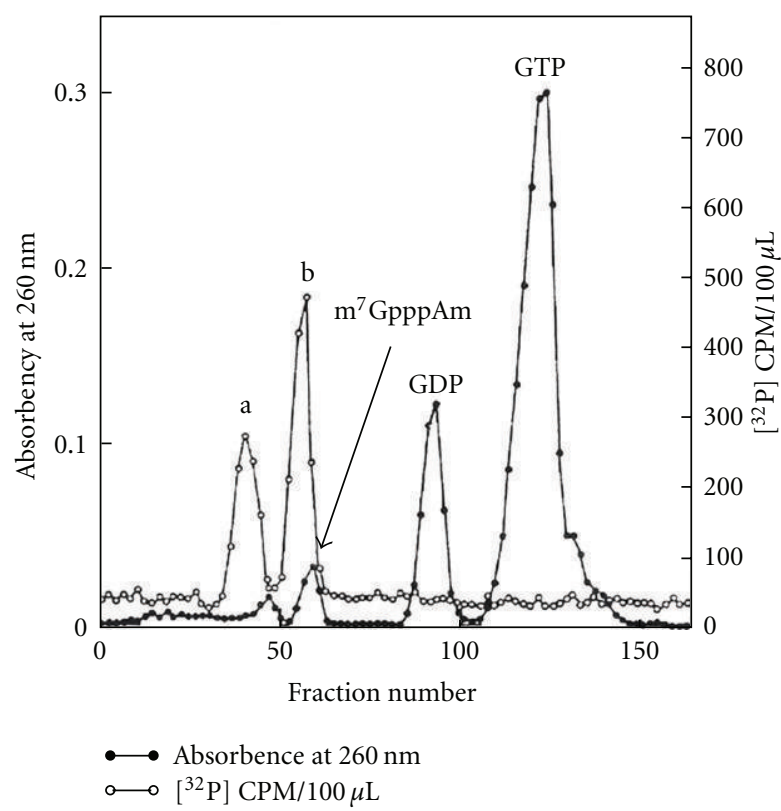

FIGURE 23: Cap core chromatography [16]. The 5' oligonucleotide eluted from the GTP region (Figure 21) was digested with P1 RNase and chromatographed on a DEAE-Sephadex A-25 column. Two peaks "a" (mononucleotides pUm and pA) and "b" (cap core $\mathrm{m}_{3}^{2,2,7} \mathrm{GpppAm}$ ) were observed.

(H/ACA snoRNA) or 2'-O-methylation (C/D snoRNA). These include U1, U2, U4, and U5 spliceosomal RNAs, and U3, U8, and U13 nucleolar RNAs. Recently, telomerase RNA (S. cerevisiae TLC1) has also been reported to have 


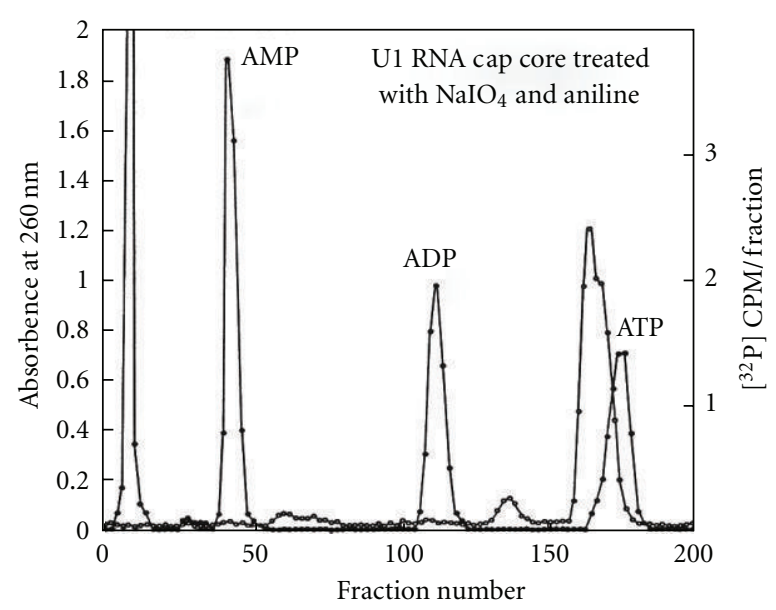

$\longrightarrow$ Absorbency at $260 \mathrm{~nm}$

$\circ\left[{ }^{32} \mathrm{P}\right] \mathrm{CPM} /$ fraction

The $\beta$-elimination mechanism of cap core $\mathrm{m}_{3}{ }^{2,2,7} \mathrm{GpppAm}$

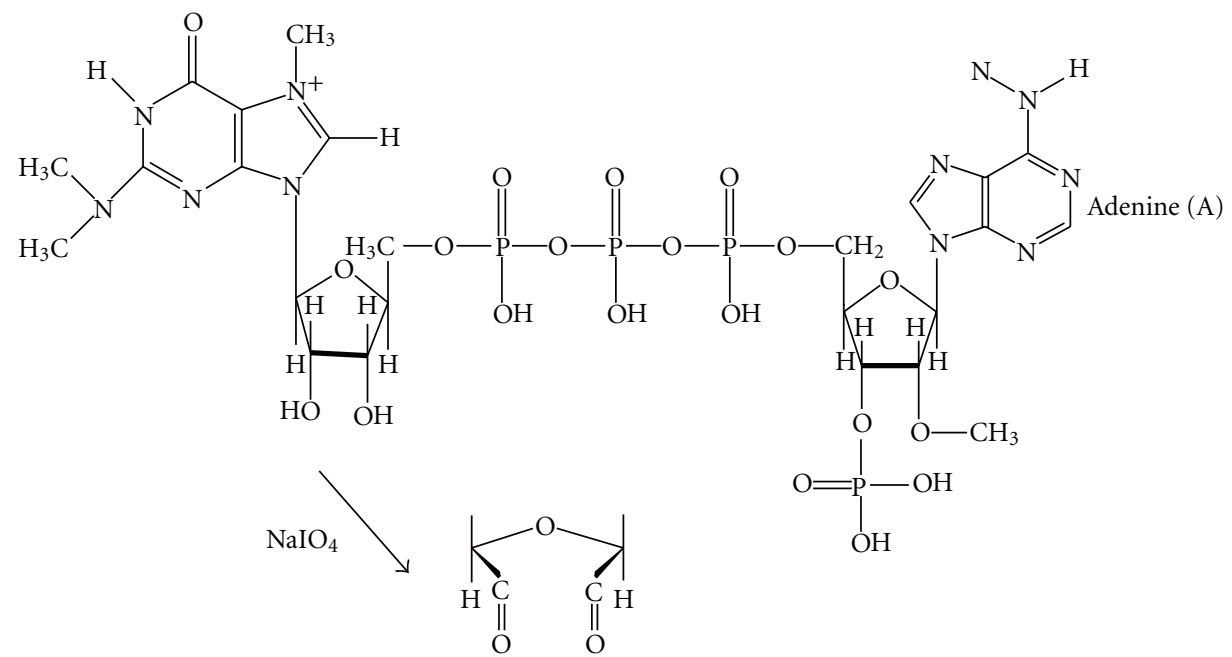<smiles>[R][N+]1=CC(=C)OC([B])C1O</smiles>

FIgURE 24: The $\beta$-elimination of cap core [16]. The cap core (peak b from Figure 23) was treated with $\mathrm{NaIO}_{4}$ and aniline to remove $\mathrm{m}_{3}{ }^{2,2,7} \mathrm{G}$ by $\beta$-elimination reaction. The remaining nucleotide was chromatographed in the ATP region indicating it is pppAm. This proved that the cap core was $\mathrm{m}_{3}^{2,2,7} \mathrm{GpppAm}$. 


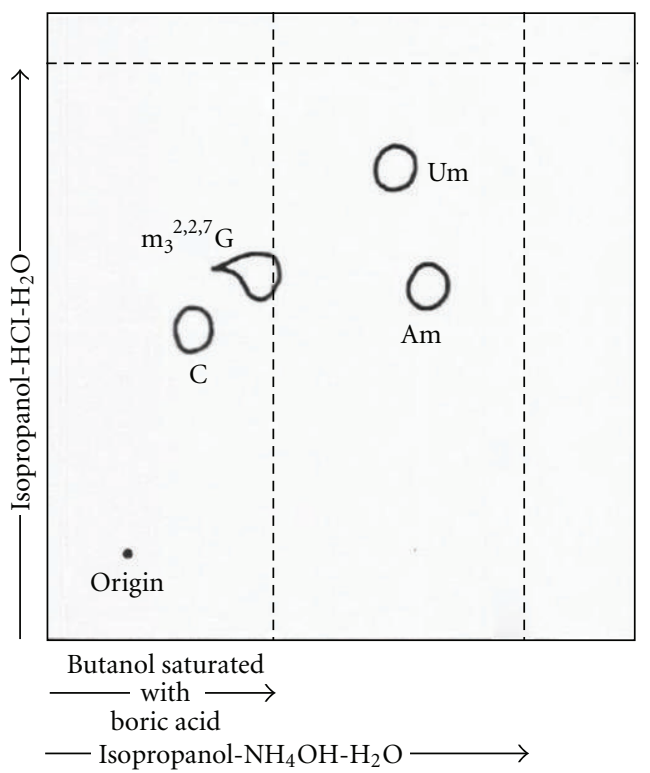

FIgURE 25: Two-dimensional chromatography in borate system [12]. The nucleoside mixture from U2 RNA 5' oligonucleotide (RNase A product) was obtained by digestion with snake venom phosphodiesterase and alkaline phosphatase. The resulting nucleosides were separated with the borate system. Um and Am migrated through the butanol-boric acid while the $\mathrm{m}_{3}^{2,2,7} \mathrm{G}$ and $\mathrm{C}$, which form borate complexes, were retained in the butanol-boric acid phase.

a trimethylguanosine cap structure. The trimethyl-G caps are formed on cap 0 or cap I of $\mathrm{m}^{7} \mathrm{G}$ caps of presnRNAs by dimethylation of $\mathrm{N} 2$ position by trimethylguanosine synthase (Tgs1). The Tgs1 has been found to be in the Cajal body and cytoplasm. The U3 snoRNA is hypermethylated in the Cajal body, and U1, U2, U4, and U5 snRNA have been reported to be hypermethylated in the cytoplasm.

11.1. The $m^{7} G$ Cap Formation. The RNA polymerase initiates the RNA transcription with $5^{\prime}$ triphosphate nucleotides and in a majority with purine nucleotides of ATP or GTP. The capping reaction in a polymerase II system occurs cotranscriptionally within the nascent transcript of $\sim 30-50$ nucleotides. The guanylyltransferase is attached to heptad (YSPTSPS) repeats of CTD of RNA polymerase II. It was reported with cloned mouse guanylyltransferase and synthetic heptad repeats that the serine 5 phosphorylated 6 heptad repeats stimulated guanylyltransferase activity 4fold. Serine 2 phosphorylation also binds the guanylyltransferase but did not stimulate enzyme activity [97].
The capping enzymes contain RNAtriphosphatase and RNA guanylyltransferase in the same molecule, but methylating enzymes are in different protein and occurs in separate steps.

The enzymes involved are RNA triphophosphatase and RNA guanylyltransferase, which can be found in the same enzyme, catalyze removal of one phosphate from pppNp initiation nucleotide, and transfer GMP from GTP through intermediary GMP-lysine phosphamide enzyme complex. The RNA guanyl 7 methyltransferase methylates the guanine at N7 position. The RNA 2'-O-methyltransferase methylates penultimate nucleotide $2^{\prime} \mathrm{OH}$, producing the cap 1 structure. In rat liver, it has been reported that 2'-O-methylation may precede the guanosine N7 methylation [98].

The capping reactions by mammalian and shrimp capping complexes (HeLa cell, rat liver, calf thymus, and shrimp) [98] have been reported as below:

RNA Triphosphatase and Guanylyltransferase. The monomer of the $69-73 \mathrm{kDa}$ protein has functions of RNA triphosphatase and RNA guanylyltransferase activity.

$$
\begin{gathered}
\text { pppNpNpNpNp- } \stackrel{\text { RNA triphosphatase }}{\longrightarrow} \text { ppNpNpNpNp- } \\
\text { GTP + RNA guanylyltransferase } \stackrel{\mathrm{Mg}^{++}}{\longrightarrow} \text { GMP- }(\text { phosphamide }) \text {-E + ppi } \\
\text { GMP-E + ppNpNpNpNp- } \stackrel{\mathrm{Mg}^{++}}{\longrightarrow} \text { GpppNpNpNpNp- + RNA guanylyltransferase } \\
\text { GpppNpNpNpNp- + AdoMet } \stackrel{\text { RNA 2'-O-methyltransferase }}{\longrightarrow} \text { GpppNmpNpNpNp- + AdoHcy } \\
\text { GpppNmpNpNpNp- + AdoMet } \stackrel{\text { RNA guanyl 7-methyltransferase }}{\longrightarrow} \mathrm{m}^{7} \text { GpppNmpNpNpNp + AdoHcy }
\end{gathered}
$$




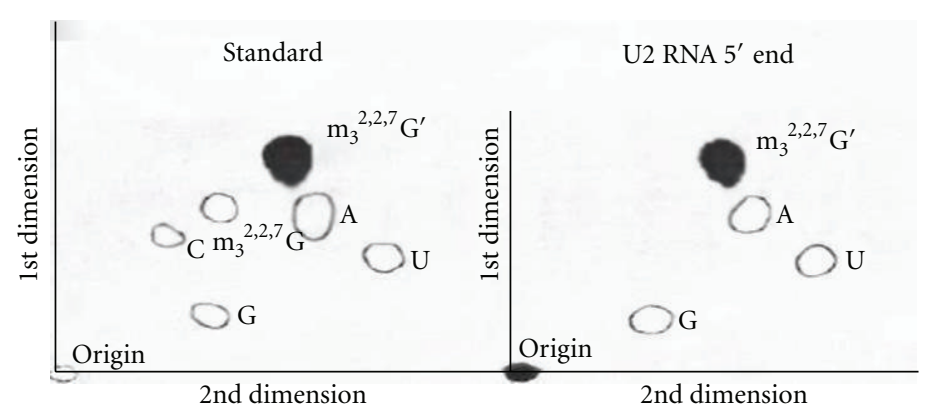

(a)

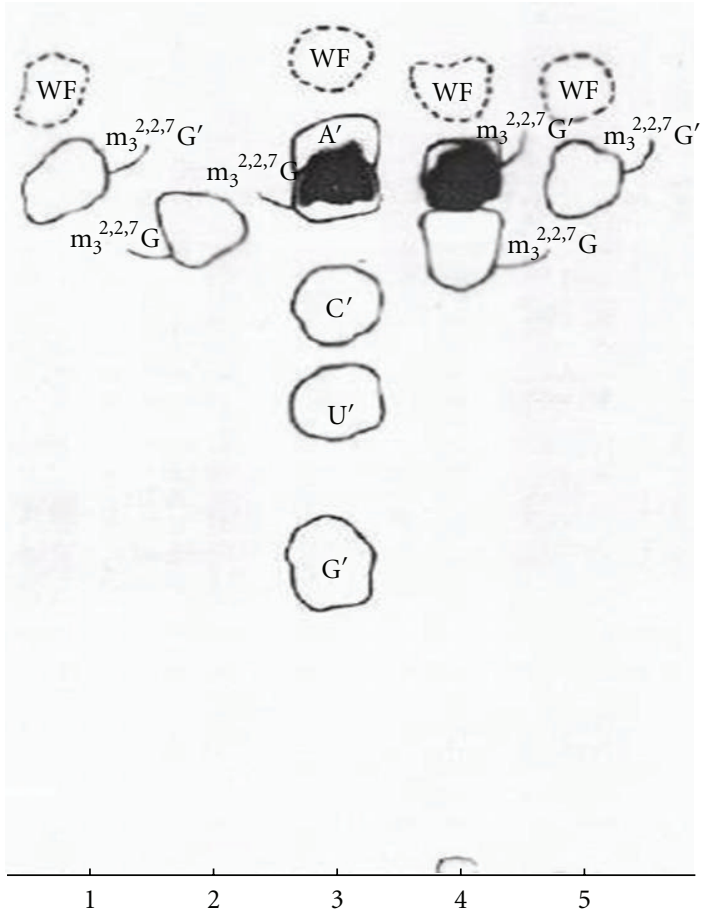

(b)

Figure 26: Fluorograph of $\left[{ }^{3} \mathrm{H}\right]$-labeled trialcohol derivatives of $\mathrm{m}_{3}{ }^{2,2,7} \mathrm{G}$ from U2 RNA $5^{\prime}$ end [12]. (a) Two-dimensional thin layer chromatography. (b) One-dimensional paper chromatography. In both systems, the labeled compound was $\mathrm{m}_{3}{ }^{2,2,7} \mathrm{G}^{\prime}$. (See text).

Some of the capping enzymes (vesicular stomatitis virus, spring viremia of carp virus) use the substrate monophosphorylated $5^{\prime}$ end (pNpNpNpNp-) $[99,100]$, and 7methylation occurs after the $2^{\prime}$-O-methylation has taken place.

Trimethylguanosine cap synthesis is carried out by multiple steps involving From HeLa cells, two enzymes forming cap I from cap 0 and cap II from cap I have been purified and characterized [101].

11.2. Cap I Methyltransferase. This enzyme is present in both the nucleus (29.3 units/mg) and cytoplasm (3.74 units/mg) and cap II methyltransferase is exclusively in the cytoplasm (4.62 units/mg). Cap I methyltransferase uses GpppA(pA) , $\mathrm{m}^{7} \mathrm{GpppA}(\mathrm{pA})_{\mathrm{n}}, \quad \mathrm{m}^{7} \mathrm{GpppApGp}, \mathrm{m}^{7} \mathrm{GpppApGpUp}$, and RNA with type 0 cap as substrates but not $\mathrm{m}^{7} \mathrm{GpppA}$ or GpppA. The substrate required for cap I formation should be at least a trinucleotide.

The order of 7-methylation of ultimate G nucleotide and $2^{\prime}$-O-methylation of penultimate nucleotide is uncertain, and both pathways may occur.

11.3. Cap II Methyltransferase. This enzyme is present only in the cytoplasm and converts cap I to cap II. The mature mRNA with $5^{\prime} \mathrm{m}^{7} \mathrm{G}$ cap and $3^{\prime}$ polyadenylation is then transported into the cytoplasm as a complex with $\mathrm{CBC} 20 / 80$, PHAX, and Crm1-RanGTP. The $\mathrm{m}^{7} \mathrm{G}$ cap binds to $\mathrm{CBC} 20$ (156 amino acids) in complex with CBC80 (790 amino acids). The crystal structure of the CBC20/80 complex in association with $\mathrm{m} 7 \mathrm{G}$ cap has been reported [86, 87]. The $\mathrm{CBC} 20$ is in an unfolded form in the absence of CBC80. The CBC80 has 3 domains, each containing consecutive 56 helical hairpins resembling the MIF4G (middle domain of eIF4G). The CBC20 has a typical RRM motif and binds between domains 2 and 3 of CBC80. The $\mathrm{m}^{7} \mathrm{G}$ cap is sandwiched between Tyr 43 and Tyr 20. And Phe 83, Phe 85, and Asp 116 have essential role for $\mathrm{m}^{7} \mathrm{G}$ cap binding. Asp 116 and Trp 115 interact with the N2 amino group and confer specificity of the $\mathrm{m}^{7} \mathrm{G}$ cap for other structures (Figure 33 ).

In the cytoplasm, the $\mathrm{m}^{7} \mathrm{G}$ cap plays a role in the initiation of translation by binding to eIF4E which complexes with eIF4A and eIF4G. The exact mechanism of exchange is not known but $\mathrm{CBC} 80$ has binding capacity for PHAX or eIF $4 \mathrm{G}$ and dissociation of CBC 80 from CBC20 makes CBC20 become disordered $[86,87]$.

11.4. Maturation of snRNAs. The snRNAs synthesized by RNA polymerase II with $\mathrm{m}^{7} \mathrm{G}$ cap structures are transported into the cytoplasm in complex with CBP20/80, PHAX (phosphorylated adaptor for RNA export), the CRM1 (export receptor, chromosome region maintenance 1) or exportin 1 and RanGTP (Ras-related nuclear antigen). The snRNPs in the cytoplasm are trimethylated and processed. The mature RNA is reimported into the nucleus in a complex with the trimethyl G cap-specific binding protein snurportin 1 and snRNA binding proteins of Sm RNP and SMN proteins.

Despite immunofluorescent staining of U1 and U2 RNA exclusively in the nucleus [102], biochemical analyses have 


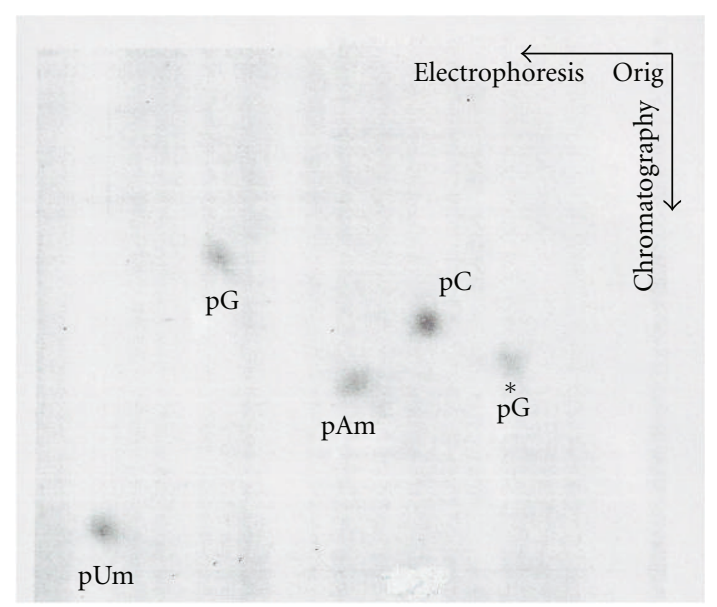

FIGURE 27: Autoradiograph of nucleotides from $\left[{ }^{32} \mathrm{P}\right]$-labeled U2 RNA $5^{\prime}$ fragment [12]. The $\left[{ }^{32} \mathrm{P}\right]$-labeled U2 RNA $5^{\prime}$ fragment (T1 RNase digestion) was treated first with alkaline phosphatase and then with snake venom phosphodiesterase. This mixture of mononucleotide products was separated by electrophoresis followed by chromatography. Approximately equal amounts of $\mathrm{pm}_{3}{ }^{2,2,7} \mathrm{G}, \mathrm{pAm}, \mathrm{pUm}, \mathrm{pC}$, and $\mathrm{pG}$ were observed (Table 11).

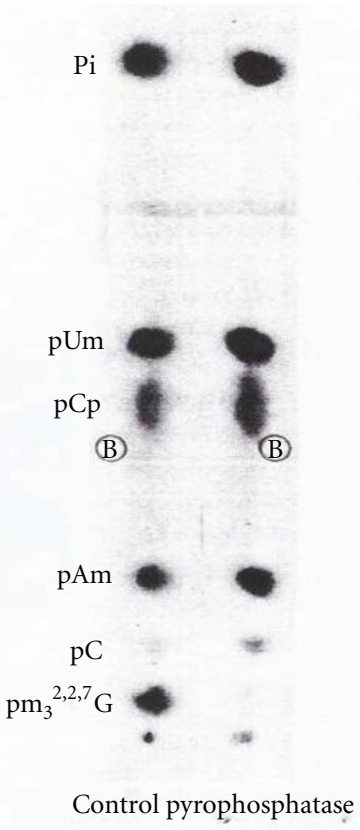

FIGURE 28: The susceptibility of $5^{\prime}$ cap to pyrophosphatase [12]. The $\left[{ }^{32} \mathrm{P}\right]$-labeled $5^{\prime}$ oligonucleotide obtained from U2 RNA by RNase A was digested with pyrophosphatase and base composition was analyzed by snake venom phosphodiesterase digestion. This digestion released $\mathrm{m}_{3}{ }^{2,2,7} \mathrm{G}$ from the $5^{\prime}$ fragment indicating that $\mathrm{m}_{3}^{2,2,7} \mathrm{G}$ is linked by a pyrophosphate linkage.

demonstrated that trimethylation and maturation of some snRNA takes place in the cytoplasm.

The U1 snRNA [103] and U2 snRNA [104] have been shown to be hypermethylated in the cytoplasm in a Sm protein binding dependent manner. The Xenopus laevis U1 RNA, with the $\mathrm{m}^{7} \mathrm{G}$ cap, has been shown to be hypermethy-

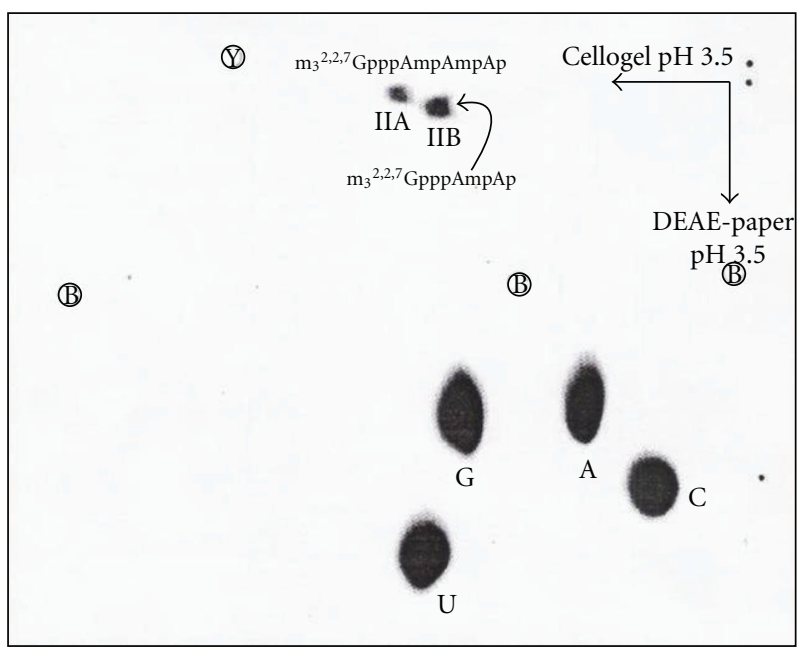

Figure 29: 2D map of U3 RNA digest [58]. The [ $\left.{ }^{32} \mathrm{P}\right]$-labeled U3 RNA was digested with $\mathrm{T}_{2}$ RNase and $\mathrm{U}_{2}$ RNase. It produced two 5 ' fragments " $11 \mathrm{~A}$ " and " $11 \mathrm{~B}$ ".

lated in HeLa cell cytoplasmic extracts and Sm binding site in U1 RNA is required [103]. The Tgs1 has been shown to bind to $\mathrm{Sm}$ proteins of Sm B and Sm D. The Xenopus laevis U2 RNA with $\mathrm{m}^{7} \mathrm{G}$ cap has been shown to be hypermethylated into the $\mathrm{m}_{3}{ }^{2,2,7} \mathrm{G}$ cap structure in enucleated xenopus oocytes [104]. In yeast and human HeLa cells, the Tgs1 for U3 RNA is localized in the nucleolar body of the nucleolus and Cajal bodies, respectively [105]. In the absence of Tgs1 or inactive Tgs1 in yeast, $\mathrm{m}^{7} \mathrm{G}$ capped unprocessed $\mathrm{U} 1$ RNA is retained in the nucleolus and splicing becomes cold temperature sensitive. The same enzyme is responsible for the U3 nucleolar RNA hypermethylation [106]. The consensus between yeast and human cells is the presence of a nucleolar body in yeast and Cajal body in HeLa cell. The hypermethylation and processing during maturation take place in the nucleolar body in yeast and Cajal body in HeLa cells $[105,106]$. The sequence element "UGAG" (also found in the U3 RNA B box) has been reported as a CAB box (Cajalbody-specific localization signal). U3 RNA trimethylation is somewhat different from other snRNAs. The U3 RNA, which does not have $\mathrm{Sm}$ protein binding sites, has been shown to require an intact $3^{\prime}$ terminal stem structure for trimethylguanosine cap formation [107].

In HeLa cells, transfected U3 RNA gene products are trimethylated and mature U3 RNA is localized in the nucleolus. Immature U3 RNA, with both $\mathrm{m}^{7} \mathrm{G}$ and $3^{\prime}$ extension of 10-15 nucleotides, is detected in Cajal bodies. The nucleolar localization requires the $\mathrm{CAB}$ box, hypermethylation to $\mathrm{m}_{3}{ }^{2,2,7} \mathrm{G}$ cap, and maturation of the $3^{\prime}$ end [105]. Unlike U1 RNA and U2 RNA, U3 RNA has been shown to be retained in the nuclear compartment and does not go into the cytoplasm for its trimethylation reaction $[105,106,108]$.

\section{The Tgs1 (Trimethylguanosine Synthase 1)}

12.1. Human Tgs1. The Tgs1, trimethylguanosine synthase in human, protein is $110 \mathrm{kDa}$ and 852 amino acids in chain 
length. The gene is located in chromosome 8q11. The mRNA is $3.2 \mathrm{~kb}$ in length and produces a $110 \mathrm{kDa}$ protein and $\sim 65$ $70 \mathrm{kDa}$ protein that is proteasome processed. The long form is in the cytoplasm, and the short isoform has been reported to be localized in the Cajal body within the nucleus. The Tgs 1 has S-AdoMet methyltransferase signature motifs of X, I, II (include post 1 motif), III, IV, V, and VI [70, 106, 109, 110].

The human Tgs1 motifs are the following.

motif $X$ is (a.a.665)DREGWFSVTPEKIAEHI/FA(a. a.682),

motif I is (a.a.693)VVVDAFCGVGGN(a.a.704),

motif II is (a.a.714)RVIAIDIDPV/IKI(a.a.725) and post 1 motif is VIAID which is responsible for SAdoMet binding to the enzyme,

motif III is (a.a.740)KIEFICGDFLLLAS(a.a.753),

motif IV is (a.a.758/759)VVFLSPPWGGPDYA(a.a. 771/772),

motif $\mathrm{V}$ is (a.a.785/786)DGFEIFRLSK(a.a.794/795), motif VI is (a.a.798/799)NNIVYFLPRNADI(a.a.810/ 811),

It was reported that trimethylation catalytic activity is located in the C-terminal region (amino acids 631-852) and this region contains the S-AdoMet-dependent methyltransferase motifs. The tryptophan in motif 4 is involved in $\pi$ stacking with $\mathrm{m}^{7} \mathrm{G}$ guanosine of the substrate. The motif 1 and post 1 motif are reported to interact with S-AdoMet. [110]. The C-terminal domain is localized in the Cajal body and binds to C/D-snoRNA- and H/ACA-snoRNA-associated proteins such as fibrillarin, Nop56, as well as dyskerin [110].

The N-terminal portion of the molecule (amino acids 1- 477) has been reported to contain GXXGXXI, a Khomology domain for RNA binding, and a motif for $\mathrm{SmB}$ and SmD1 binding. The Tgs1 has also been shown to interact with PRIP (proliferator-activated receptor-interacting protein), and the $\mathrm{N}$-terminal portion (amino acids 1-384) of Tgs1 has been shown to have stimulatory effects on transcription of PPAR $\gamma$ and $\operatorname{RXR} \alpha[109,110]$.

The human Tgs1 (618-853) has been crystallized for structural analysis. The one monomer consists of $11 \alpha$ helices and $7 \beta$-strands. It is composed of 2 domains, the core domain (Glu675-Asp844) and N-terminal extension (Leu34Ser671) connected by 3 amino acids-Val672, Thr673, and Ser674. The core domain consists of 7 - $\beta$-strands in topology of $\beta 6 \uparrow \beta 7 \downarrow \beta 5 \uparrow \beta 4 \uparrow \beta 1 \uparrow \beta 2 \uparrow \beta 3 \uparrow$ with a classical class 1 methyltransferase fold resembling the Rossmannfold AdoMet-dependent methyltransferase superfamily [90]. The N-terminal $\alpha$-helices form a separate small globular subdomain involved in recognition and binding of both substrates. The residues Glu667 and Phe670 in motif X as well as Pro765, Trp 766, and Pro769 in motif IV are in proximity permitting the top of their binding clefts to be close together. Tryptophan 766 and $\mathrm{m}^{7} \mathrm{G}$ are stacked in a coplanar manner with a $3.2 \AA$ distance providing a tight $\pi$ $\pi$ interaction between them (Figure 34).

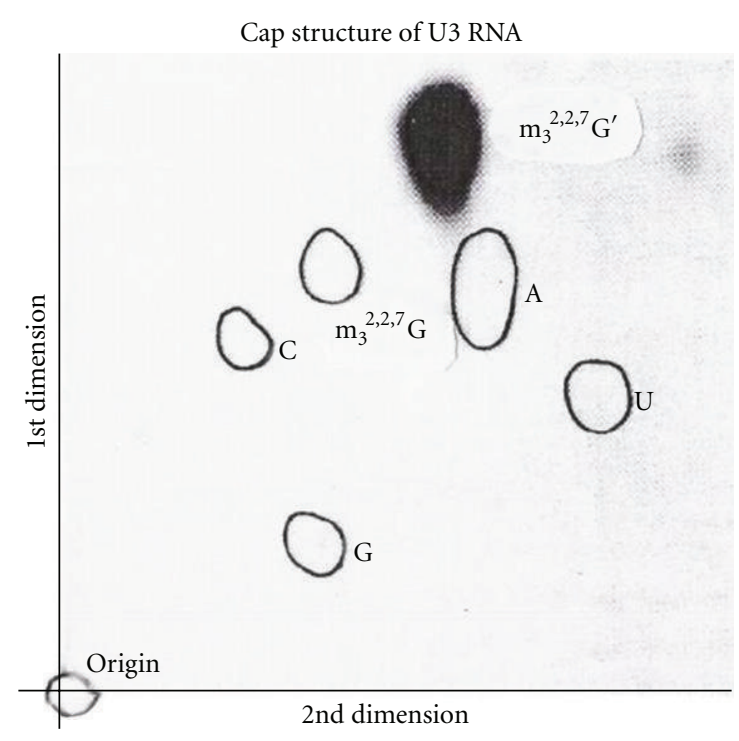

(a)

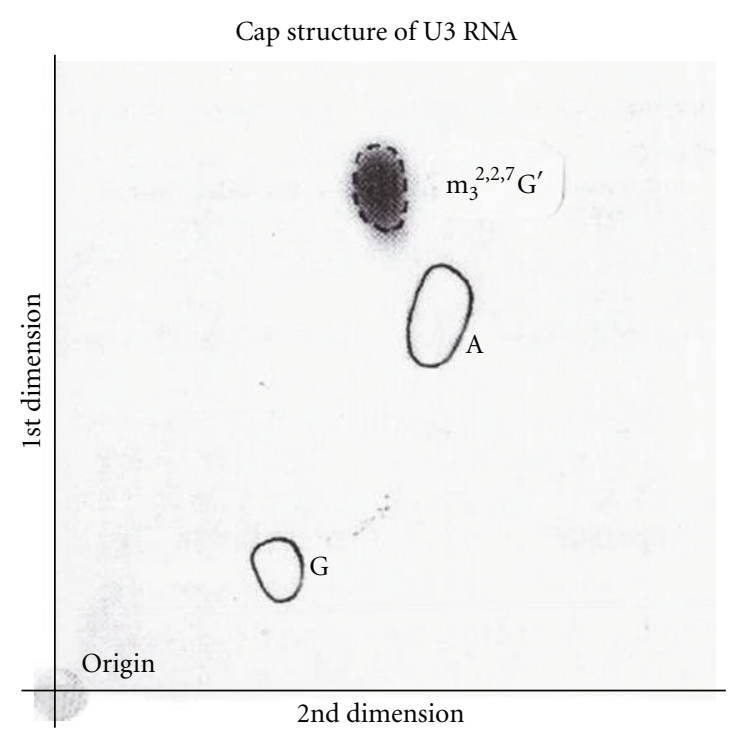

(b)

Figure 30: $\mathrm{m}_{3}{ }^{2,2,7} \mathrm{G}^{\prime}$ identification from U3 RNA $5^{\prime}$ end fragment [58]. The $\left[{ }^{3} \mathrm{H}\right]$-labeled U3 RNA $5^{\prime}$ fragment obtained by RNase $\mathrm{T}_{1}$ and RNase $\mathrm{A}$ was digested with snake venom phosphodiesterase and alkaline phosphatase. The nucleoside mixture was separated by twodimensional thin layer chromatography with standard nucleoside mixture in (a) and with the trialcohol derivative of $\mathrm{m}_{3}^{2,2,7} \mathrm{G}^{\prime}$ in (b). The released nucleoside trialcohol derivative was identified as $\mathrm{m}_{3}{ }^{2,2,7} \mathrm{G}^{\prime}$ by fluorography.

The catalytic mechanism of methylation is by an $\mathrm{S}_{\mathrm{n}} 2$ substitution reaction. The $\mathrm{N} 2$ of $\mathrm{m}^{7} \mathrm{G}$ does the nucleophilic attack on an activated methyl group of the AdoMet (Figure 35).

Dimethylation is not processive. After formation of $\mathrm{m}_{2}{ }^{2,7} \mathrm{G}$ both products $\left(\mathrm{m}_{2}{ }^{2,7} \mathrm{G}\right.$ and AdoHcy) dissociate from the enzyme. Tgs1 can use $\mathrm{m}_{2}{ }^{2,7} \mathrm{G}$ as a substrate, and newly bound AdoMet can methylate at the same position by the same mechanism to form the $\mathrm{m}_{3}{ }^{2,2,7} \mathrm{G}$ cap structure. 


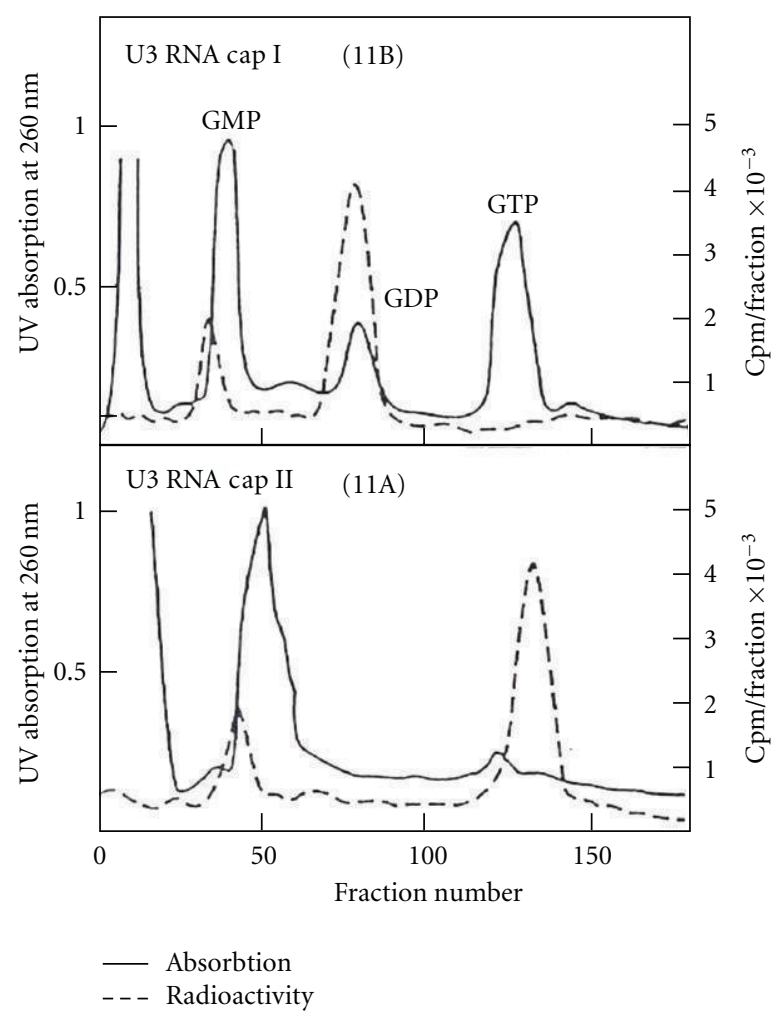

Figure 31: U3 RNA cap I and cap II chromatography [58]. The $5^{\prime}$ fragment from Figure 29 was eluted and treated with alkaline phosphatase and chromatographed on DEAE-Sephadex A-25 with standards of GMP, GDP, and GTP. Component "11B" was eluted in the GDP (cap I, m ${ }_{3}^{2,2,7} \mathrm{GpppAmA}$ ) region and " $11 \mathrm{~A}$ " (cap II, $\mathrm{m}_{3}{ }^{2,2,7} \mathrm{GpppAmAmA}$ ) was eluted in the GTP region.

12.2. Drosophila Tgs1. In Drosophila melanogaster, DTL (Drosophila TAT-like) has been reported to exhibit trimethylguanosine cap formation activity for both $\mathrm{U} 2$ and U4 snRNAs. The mRNA for the protein Tgs1 is polycistronic and 2,600-nucleotide long with upper and downstream ORFs (open reading frames). The uORF is $80 \mathrm{bp}$ from the transcription start site and has coding capacity for a 178 amino acid protein while dORF is $538 \mathrm{bp}$ from the $5^{\prime}$ end and produces a $60 \mathrm{kDa}$ protein (491 amino acids). The two cistrons are overlapped by $76 \mathrm{bp}$. Mutational analysis indicates that both the UORF and dORF regions are required for viability. The putative product of $\mathrm{UORF}$ contains periodic Leu residues, but there is no evidence that this region is translated at any time during Drosophila development. The protein from dORF contains an Arg-rich motif KKKRRQRQI similar to the RNA binding motif RKKRRQRRR in HIV TAT. This protein is localized in the nucleus and responsible for trimethylation of $\mathrm{U} 2$ and $\mathrm{U} 4$ snRNAs [111].

12.3. Yeast Tgs1. In yeast S. cerevisiae, Tgs 1 is in the nucleolus and U3 RNA is also in the nucleolus. In the absence of Tgs1, the pre-U3 RNA was found within the nucleolar body and U1 RNA was retained in the nucleolus. S. cevisiae, S. pombe, and Giardia lamblia Tgs 1 can methylate $\mathrm{m}^{7} \mathrm{GTP}, \mathrm{m}^{7} \mathrm{GDP}$, and $\mathrm{m}^{7} \mathrm{GpppA}$ as substrates without preassembly of snRNP containing Sm proteins. The Tgs 1 of S pombe is 239 -aminoacid long and $\mathrm{m}^{7} \mathrm{G}$ is the pre-requisite for this reaction [112].

12.4. The G. lamblia Tgs1 and Tgs2. The lamblia has 2 enzymes, Tgs 1 and Tgs 2 . Tgs 1 is not a processive enzyme but distributive and produces $\mathrm{m}_{3}{ }^{2,2,7} \mathrm{G}$ in excess of AdoMet and enzyme. However, Tgs 2 produces only $\mathrm{m}_{2}{ }^{2.7} \mathrm{G}$, and some $\mathrm{G}$. lamblia RNAs contain dimethylG caps. The $\mathrm{G}$ lamblia Tgs1 has 300 amino acids and Tgs 2 is 258 amino acids long. They all have landmark motifs for Ado-Met-dependent methyltransferase motifs [113].

\section{Parasite Capping Enzyme (Trypanosoma brucei)}

The parasite Trypanosoma brucei SL RNA (splicing leader) has the biggest $5^{\prime}$ oligonucleotide, type IV, of $\mathrm{m}^{7} \mathrm{Gpppm}_{2}{ }^{6,6} \mathrm{AmpAmpCmpm}{ }^{3} \mathrm{UmpAp} \quad[114,115]$. Enzymes involved in the synthesis of this cap structure are TbCgm1, TbCet1, TbMTr1(cap1 2'OMTase), TbMTr2/ TbCom1/TbMT48(cap2 2'OMTase), TbMTr3/ TbMT57(cap3 $2^{\prime}$ OMTase). However, $\mathrm{m}_{2}{ }^{6,6} \mathrm{~A}$ and $\mathrm{m}^{3} \mathrm{Um}$ methylating enzymes have not been identified as yet [115].

13.1. TbCgm1 (T. brucei Cap Guanylyltransferase Methyltransferase 1). There exist two enzyme systems for $5^{\prime}$ cap formation. The first is the system composed of separate independent enzymes which are TbCetl (Trypanosoma brucei triphosphatase, 253 amino acids), TbCe1 (Trypanosoma brucei guanylyltransferase, 586 amino acids), and TbCmt1 (Trypanosoma brucei $\mathrm{m}^{7} \mathrm{G}$ Cap methyltransferase 1, 324 amino acids). The second is a set of fused enzymes possessing dual activities. It is TbCgm1 (Trypanosoma brucei cap guanylyltransferase and methyltransferase 1) that has 1050 amino acids [116] with dual activities of guanylyltransferase and guanine N-7 methyltransferase [117]. The TbCe1 guanylyltransferase has 250 amino acids at its $\mathrm{N}$-terminal region which is not found in fungal or metazoan guanylyltransferase and has homology with the phosphate binding loop found in ATP- and GTP-binding proteins [118]. Silencing TbCe1 and TbCmtl had no effect on parasite growth or SL RNA capping, but TbCgm1 was essential for parasite growth and silencing TbCgml increased the amount of uncapped SL RNA. The protein TbCgm1 has guanylyltransferase activity in N-terminal 1-567 amino acids and methyltransferase activity in C-terminal 717-1050 amino acids. The Nterminal guanylyltransferase portion contains 6 colinear guanylyltransferase motifs: I(KADGTR), III(FVVDAELM), IIIa(LIGCFDVFRYVI), IV(DGFIF), V(QLXWKWPSMLSVD), and VI(WSIERLRNDK). The C-terminal methyltransferase por-tion contains regions homologous to $\mathrm{m}^{7} \mathrm{G}$ methyltransferase from T. cruzi and L. major [117].

13.2. Cap Methylating Enzymes: TbMTr1, TbMTr2(TbCom1/ TbMT48), and TbMTr3(TbMT57). They contain a $\mathrm{K}^{95}$ $\mathrm{D}^{207}-\mathrm{K}^{248}-\mathrm{E}^{285}$ tetrad critical for AdoMet-dependent 

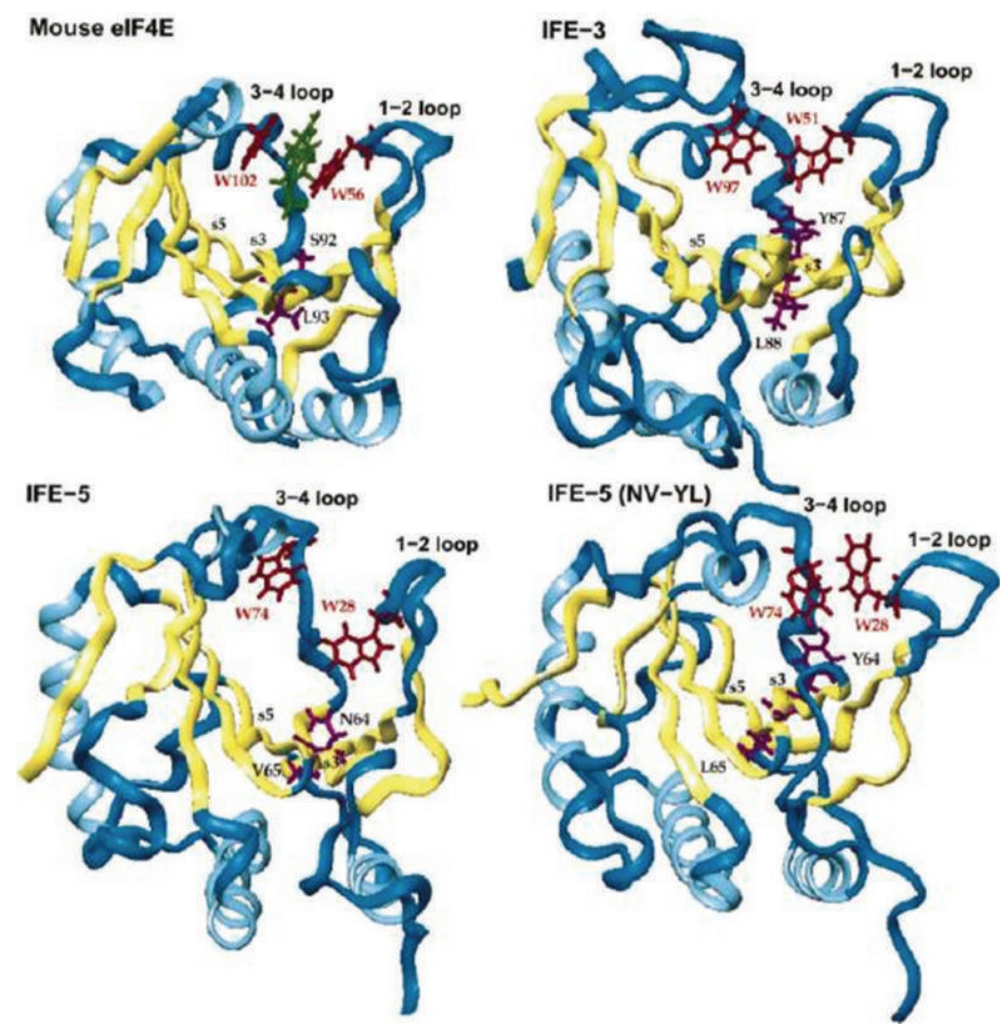

Figure 32: Molecular models of IFE-3, IFE-5, and IFE-5 (NV-YL) in comparison with mouse eIF4E [85]. The differences between the $\mathrm{m}^{7} \mathrm{G}$ cap binding pocket and $\mathrm{m}_{3}^{2,2,7} \mathrm{G}$ cap binding pocket are illustrated by differences in the 3-4 loop configuration.
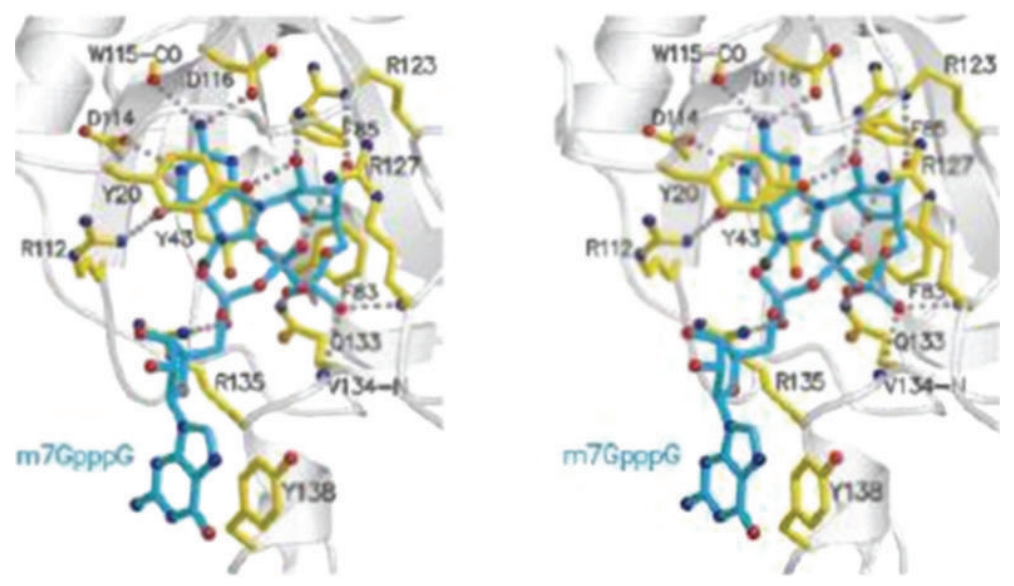

Figure 33: CBP20 (cap binding protein 20) binding to $\mathrm{m}^{7} \mathrm{G}$ cap $[86,87]$. The $\mathrm{m}^{7} \mathrm{G}$ is stabilized by stacking energies between tyrosine 20 and tyrosine 43 .

methyltransferase and can convert cap type 0 of Trypanosoma SL RNA and U1 snRNA into type 1 cap [115]. The KDKE mediates $S_{n} 2$ type transfer of methyl groups that involve $2^{\prime}-\mathrm{OH}$ deprotonation. The U1 snRNA 2'-O-methylation takes place before $\mathrm{Sm}$ protein binding to the RNA and it is prerequisite for the dimethylation at the $\mathrm{N} 2$ position to make $\mathrm{m}_{3}{ }^{2,2,7} \mathrm{GpppAm}$ cap structures. Other $\mathrm{m}_{3}^{2,2,7} \mathrm{G}$ cap-containing snRNAs such as U2, U-snRNA B (U3 snRNA homolog), and U4 snRNAs were reported to be synthesized by RNA polymerase III in Trypanosomes.

The TbMTr2 and TbMTr3 are responsible for second and third nucleotides $2^{\prime}$-O-methylations. The enzymes that perform $\mathrm{m}_{2}{ }^{6,6} \mathrm{~A}, \mathrm{~m}^{3} \mathrm{U}$ base methylations, and fourth nucleotide $2^{\prime}$-O-methylating enzymes are not known yet. 


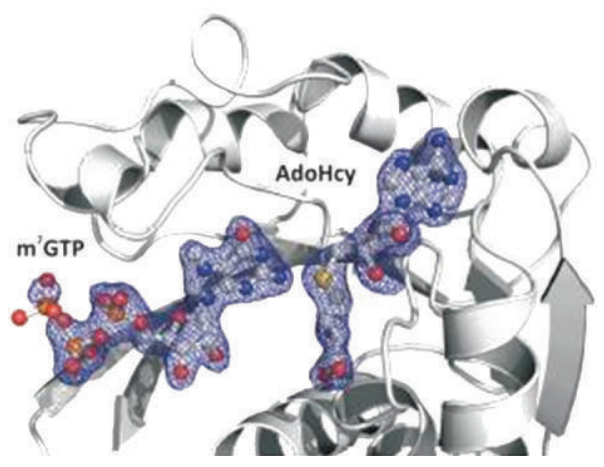

(a)

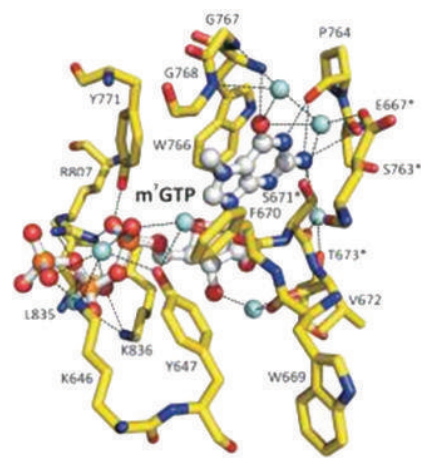

(b)

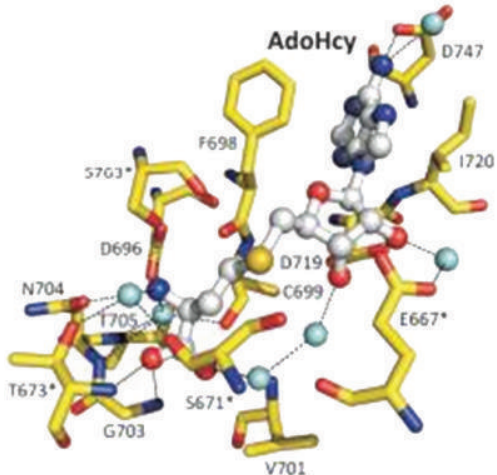

(c)

FIGURe 34: Crystal structure of hTgs1 [90]. The crystal structure of hTgs1 with substrate $\mathrm{m}^{7} \mathrm{GTP}$ and AdoHcy (at the site for AdoMet). The $\mathrm{m}^{7} \mathrm{G}$ is stacked between tryptophan 766 and serine 671 [90]. (a) Relative orientation of substrates $\mathrm{m}^{7} \mathrm{GTP}$ and AdoHcy at binding pockets. (b) Detailed view of the binding pocket for $\mathrm{m}^{7} \mathrm{GTP}$ (shown W766 and S671). (c) Detailed view of the binding pocket for AdoHcy.

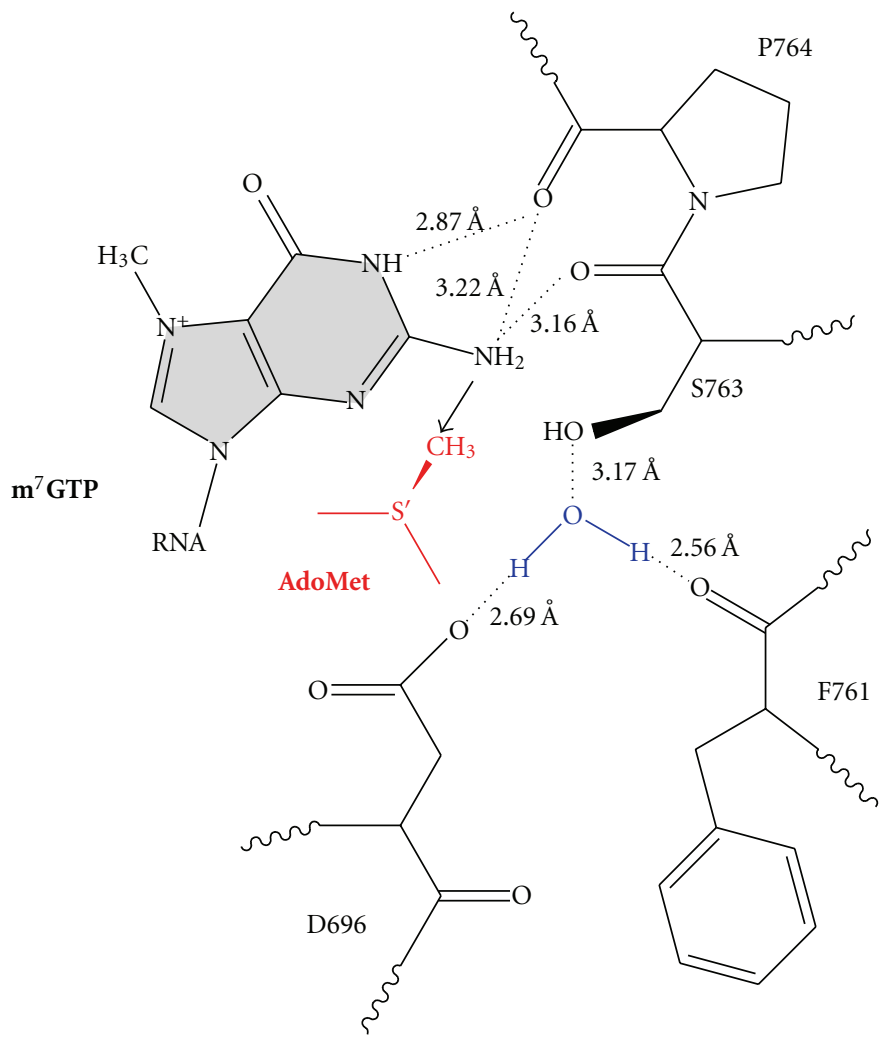

FIgure 35: The active site of hTgs1 [90]. Proposed mechanism of methyltransferase activity of hTgs1 is shown. The AdoMet methyl group is in close proximity to $\mathrm{N} 2$ position of $\mathrm{m}^{7} \mathrm{GTP}$. The prerequisite as a substrate for hTgs 1 is $\mathrm{m}^{7} \mathrm{G}$ moiety.

\section{Transport of Mature RNAs}

The snurportin1 is a specific trimethyl $\mathrm{G}$ cap binding protein with an importin $\beta$ binding site at its $\mathrm{N}$-terminus (amino acids 1-65) and trimethyl $G$ cap binding site at amino acids 95-300 forming a cap binding pocket. This protein has more resemblance to mRNA guanylyltransferase. The snurportin 1 binds the trimethyl $\mathrm{G}$ cap forming $\pi$ stacking with tryptophan 276 and the penultimate purine nucleotide G (Figure 36). The tryptophan 107 is in close proximity to dimethylamine of $\mathrm{N} 2 \mathrm{G}$ suggesting a cation- $\pi$ interaction and has a role in discriminating between $\mathrm{m}^{7} \mathrm{G}$ cap and $\mathrm{m}_{3}{ }^{2,2,7} \mathrm{G}$ cap [91].

\section{Tgs 1 Interacting Proteins}

Genetic and biochemical analysis of Tgs1 interacting proteins reveals a wide range of proteins involved in RNA metabolism. 

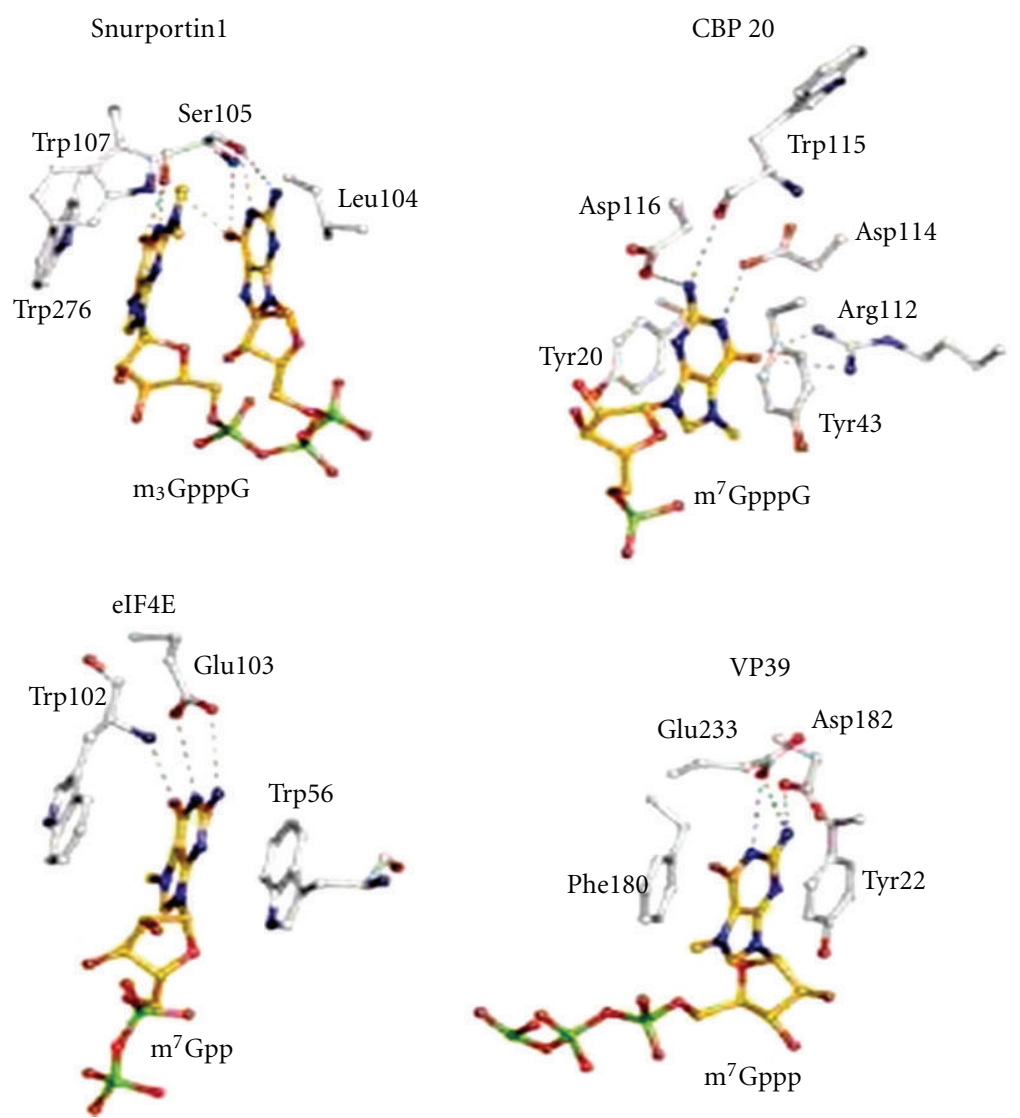

FIGURE 36: The comparison between $\mathrm{m}_{3}^{2,2,7} \mathrm{G}$ binding mode to snurportin 1 and $\mathrm{m}^{7} \mathrm{G}$ cap binding mode to CBP 20, eIF4E and VP39 [91]. The $\mathrm{m}_{3}{ }^{2,2,7} \mathrm{G}$ is stacked between tryptophan 107 and penultimate nucleotide $\mathrm{G}$ of cap core $\mathrm{m}_{3}{ }^{2,2,7} \mathrm{GpppG}$.

\section{pppGGUCGAGAGG AUGGCUCAGC CGUUAA[AG]GC UAGGCCAAAA AUAA \{CACCUA \\ U\} AAGAGUUCG GUUCCC[AG]CA CCACGGCUGU CCUUCCAGCA CCUUUU-OH}

FIgURE 37: The sequence of 4.5S RNA I (Novikoff hepatoma cell nuclei).

It interacts with proteins in the transcriptional apparatus, RNA end processing and decay, spliceosomal assembly and RNA modifying factors (Table 12).

Structurally, it is distinct from the $\mathrm{m}^{7} \mathrm{G}$ cap, and the specificity of binding proteins may determine the precision of its functional role in the RNP complex. The $\mathrm{m}_{3}{ }^{2,2,7} \mathrm{G}$ cap structures are present only in nuclear snRNAs and snoRNAs which confer the function within the nucleus in transcription, splicing, modification, processing, and maturation of different RNA species.

\section{Conclusion}

16.1. General Consideration. In the present postgenomic era, study of the structure and function of noncoding RNAs is supremely important. It is estimated that ncRNAs are probably involved in all aspects of cell metabolism. Therefore, RNA-based information will contribute greatly to understanding various cell metabolisms. In the process of exploring ncRNAs, there may be many surprises awaiting us.

They may include

(1) new species of RNA,

(2) new mechanism of RNA processing,

(3) new mechanism of transcription,

(4) new disease caused by RNAs with pathogenic sequences,

(5) new function for ncRNA.

16.2. The Problem of Unknown Modified Nucleotides. In the process of oligonucleotides cataloging, it is natural that an examination of base composition will reveal modified nucleotides or nucleosides in addition to unmodified standard nucleotides or nucleosides. In routine work, identification of modifications can be readily made by 
two-dimensional paper chromatography for nucleotides or thin layer chromatography for nucleosides. However, there may be an occasion where chromatographic identification is not sufficient. Of course, it is best to have collaboration with outside specialists. For the sake of structural microanalysis, it is highly recommendable to determine molecular weight of the unknown nucleotide or nucleoside by mass spectrometry [119]. The required quantity is approximately $5 \mu \mathrm{g} / \mathrm{nt}$ where chromatographic identification of isotopically labeled sample requires $0.5 \mu \mathrm{g} / \mathrm{nt}$. A difficulty may be confronted with purine bases that are fused to an imidazole ring (Queuosine) which is not suited for mass spectrometry. It is convenient to probe chemical complexity based on mass. The detailed analysis may require an unpredictably large amount of samples. There are 135 modified nucleosides listed, among which 6 nucleosides are not thoroughly identified [1].

16.3. Significance of Sequence Work. Past sequence work has permeated numerous significant areas of research providing a better understanding of cellular metabolism. The information obtained thus far is RNA-based information which is not seen in DNA, proteins, and others. As sequence work continues to make enormous progress, the postgenomic era will shape the direction of research in the area of molecular mechanisms of RNA metabolism. They are briefly as follows.

In RNA maturation, knowledge of structural modifications is necessary to discern between various mechanistic options. For example, there are two molecular mechanisms mediated by catalysis. One is mediated by RNA enzymes (snRNAs and snoRNAs) involved in splicing of pre-mRNA and processing of pre-rRNA. The other is protein enzymes involved in $5^{\prime}$ cap formation. Currently, the higher order structural analysis is in progress. There is a need to elucidate the details of molecular mechanisms.

Along with the study of splicing physiology, splicing pathology is making significant progress. Aberrant modifications can generate disease causing alterations in structure. The aberrations cause problems in reading both genetic codes and splicing codes. Studying the regulation of alternative splicing will clarify the selective rules in intron removal and pathogenic rules in splicing code. From these studies, corrective strategy will evolve. The present sequence work is engaged in definition of ncRNAs diversity and their functional roles [120]. Since it is suggested that ncRNAs are involved in all aspects of regulations in cell metabolism, there may be opportunities to study various paths in cell metabolism, not limited to transcriptional and posttranscriptional events. It is this gigantic task, to reevaluate the genomic work, that holds excitement and promise.

\section{Abbreviations Used in Table 4}

Short Noncoding RNA (Usually Shorter Than tRNA and Some Are Longer but Excluding snRNA Such As U1-U13)

miRNA: MicroRNA (imperfect base pairing)

siRNA: Small interfering RNA (perfect base pairing)
tasiRNA: Transacting small interfering RNA

natsiRNA: Natural antisense transcribed small interfering RNA

piRNA: PIWI interacting RNA (RNA precipitated by PIWI protein antibody)

rasi RNA/pitRNA: Repeat-associated small interfering RNA/pi-target RNA

PARs: promoter associated RNAs

PROMTs: Promoter upstream transcripts (sense and antisense transcript)

PASRs: Promoter-associated small RNAs

TSSa-RNAs: Transcription-start-site-associated RNAs

tiRNAs: Transcription initiation RNAs

MSY-RNA: MSY2-associated RNAs (MSY; Y chromosome male-specific protein)

snoRNA: Small nucleolar RNA (C/D box RNA, H/ACA RNA)

sdRNA: sno-derived RNAs

moRNA: MicroRNA-offset RNAs

tel-sRNA: Telomere small RNAs

crasiRNA: Centrosome-associated small interfering RNAs

hsRNA: Heterochromatin small RNA or hairpin small RNA

scaRNAs: Small Cajal-body-associated RNAs

Y RNAs: Cytoplasmic small RNA Y1, Y3, Y4, and Y5

tRNA-derived RNAs: Small RNA processed from tRNA by RNase (angiogenin)

Alu/SINE RNA: Alu restriction enzyme cleaved repeat gene transcript/short interspersed nucleotide element RNA.

Lnc RNA: Long Noncoding RNA ( 0.5 to $100 \mathrm{~kb})$

(1) Specific Long Noncoding RNA

TR/TERC: Telomerase RNA/telomerase RNA component

NEAT RNAs: Nuclear enriched abundant transcript 1 RNAs

NEAT1v-1: NEAT1 variant 1

NEAT1v-2: NEAT1 variant 2

NEAT2/MALAT1: Metastasis associated in lung adenocarcinoma transcript 1

PINC RNA: Pregnancy-induced noncoding RNA

DD3/PCA3: Prostate-cancer-associated RNA 3

PCGEM1: Prostate cancer gene expression marker 1

SPRY4-1T1: Sprouty homolog 4 gene transcript 1 (melanoma specific). 
(2) Imprinting-Associated $\operatorname{lncRNAs}$

xiRNAs: X chromosome inactivating RNAs

Xist: X chromosome inactivating sense RNA

Tsix: Antisense transcript of Xist

RepA: Repeat A RNA

AIR RNA: Igf2r imprinting region RNA

H19: Igf2 imprinting region RNA

KCNQ1ot1: Antisense RNA from intron 10 of Kcng1 gene imprinting region.

(3) Regulatory $\operatorname{lncRNAs}$

HOTAIR: Homeogene inactivating RNA

BORG: BMP/OP-responsive-gene-associated RNA

CTN RNA: Cationic amino acid transporter protein coding region RNA

ANRIL RNA: Antisense noncoding RNA in INK4 locus.

\section{(4) Gene-Recombination-Associated IncRNA}

LINE: long interspersed nucleotide element

CSR-RNA: Immunoglobulin class switch recombination region RNA.

\section{(5) Satellite DNA Transcripts.}

\section{Abbreviations for Table 12}

Mud: Mutant U1 die

RES complex: Heterotrimeric RNA retention and splicing complex composed of Bud13, Ist3/Snu17, and Pml1

Swt21: Synthetic with Tgs1 number 21

TRAMP complex (Trf4, Air2, Mtr4p polyadenylation complex): Interacts with exosome in the nucleus and involved in $3^{\prime}$ end processing of rRNA, snoRNA, and $\mathrm{U} 1, \mathrm{U} 4$, and U5 snRNA;

Trf4 or Trf5: poly(A) polymerase(PAP);

Mtr4: RNA helicase;

Air1 or Air2: Zinc knuckle protein

Cbf5(YLR175W): Centromere binding factor;

Pseudouridine synthase catalytic subunit of box H/ACA snoRNP complex

PIMT: PRIP-interacting protein with methyltransferase domain, PIMT is a Tgs1 (trimethylguanosine synthase 1) cloned from human liver cDNA library

PRIP: PPAR interacting protein

PPAR: Peroxisome proliferator-activated receptor PBP: PPAR binding protein.

\section{Acknowledgment}

The authors are indebted to Professor Lynn Yeoman of Baylor College of Medicine for helpful discussion in the preparation of this paper.

\section{References}

[1] S. Dunin-Horkawicz, A. Czerwoniec, M. J. Gajda, M. Feder, H. Grosjean, and J. M. Bujnicki, "MODOMICS: a database of RNA modification pathways," Nucleic Acids Research., vol. 34, pp. D145-D149, 2006.

[2] T. A. Cooper, L. Wan, and G. Dreyfuss, "RNA and Disease," Cell, vol. 136, no. 4, pp. 777-793, 2009.

[3] J. D. Watson and F. H. C. Crick, "Molecular structure of nucleic acids: a structure for deoxyribose nucleic acid," Nature, vol. 171, no. 4356, pp. 737-738, 1953.

[4] I. R. Lehman, M. J. Bessman, E. S. Simms, and A. Kornberg, "Enzymatic synthesis of deoxyribonucleic acid. I. Preparation of substrates and partial purification of an enzyme from Escherichia coli," Journal of Biological Chemistry, vol. 233, no. 1, pp. 163-170, 1958.

[5] M. J. Bessman, I. R. Lehman, E. S. Simms, and A. Kornberg, "Enzymatic synthesis of deoxyribonucleic acid. II. General properties of the reaction," Journal of Biological Chemistry, vol. 233, no. 1, pp. 171-177, 1958.

[6] M. Muramatsu and H. Busch, "Isolation, composition, and function of nucleoli of tumors and other tissues," in Methods in Cancer Research, H. Busch, Ed., vol. 2, Chapter 9, pp. 303359, Academic Press, New York, NY, USA, 1967.

[7] T. S. Ro-Choi and H. Busch, "Low-molecular-weight nuclear RNAs," in The Cell Nucleus, H. Busch, Ed., chapter 5, Academic Press, New York, NY, USA, 1974.

[8] J. Sperling, M. Azubel, and R. Sperling, "Structure and function of the pre-mRNA splicing machine," Structure, vol. 16, no. 11, pp. 1605-1615, 2008.

[9] K. Randerath and E. Randerath, "A tritium derivative method for base analysis of ribonucleotides and RNA," Procedures in Nucleic Acid Research, vol. 2, pp. 796-828, 1971.

[10] J. A. Gerlt, "Mechanistic principles of enzyme-catalyzed cleavage of phosphodiester bonds," in Nucleases, S. M. Linn, R. S. Lloy, and J. R. Roberts, Eds., chapter 1, Cold Spring Harbor Laboratory, New York, NY, USA, 1993.

[11] Y. Motorin, S. Muller, I. Behm-Ansmant, and C. Branlant, "Identification of modified residues in RNAs by reverse transcription-based methods," Methods in Enzymology, vol. 425, pp. 21-53, 2007.

[12] T. S. Ro-Choi, Y. C. Choi, D. Henning, J. McCloskey, and H. Busch, "Nucleotide sequence of U2 ribonucleic acid. The sequence of the 5' terminal oligonucleotide," Journal of Biological Chemistry, vol. 250, no. 10, pp. 3921-3928, 1975.

[13] L. Cartegni, J. Wang, Z. Zhu, M. Q. Zhang, and A. R. Krainer, "ESEfinder: a web resource to identify exonic splicing enhancers," Nucleic Acids Research, vol. 31, no. 13, pp. 35683571, 2003.

[14] J. Brachet, The Biological Role of Ribonucleic Acids, Weizman Memorial Lecture Series, The Netherlands Elsevier Publishing, 6th edition, 1960.

[15] C. Branlant, A. Krol, J. P. Ebel et al., "Nucleotide sequences of nuclear U1A RNAs from chicken, rat and man," Nucleic Acids Research, vol. 8, no. 18, pp. 4143-4154, 1980. 
[16] T. S. Ro-Choi and D. Henning, "Sequence of 5' oligonucleotide of U1 RNA from Novikoff hepatoma cells," Journal of Biological Chemistry, vol. 252, no. 11, pp. 3814-3820, 1977.

[17] C. Branlant, A. Krol, J. P. Ebel, E. Lazar, B. Haendler, and M. Jacob, "U2 RNA shares a structural domain with U1, U4, and U5 RNAs,” EMBO Journal, vol. 1, no. 10, pp. 1259-1263, 1982.

[18] H. Shibata, T. S. Ro Choi, R. Reddy, Y. C. Choi, D. Henning, and H. Bush, "The primary nucleotide sequence of nuclear U2 ribonucleic acid. The 5' terminal portion of the molecule," Journal of Biological Chemistry, vol. 250, no. 10, pp. 3909-3920, 1975.

[19] D. Suh, H. Busch, and R. Reddy, "Isolation and characterization of a human U3 small nucleolar RNA gene," Biochemical and Biophysical Research Communications, vol. 137, no. 3, pp. 1133-1140, 1986.

[20] K. A. Parker and J. A. Steitz, "Structural analysis of the human U3 ribonucleoprotein particle reveal a conserved sequence available for base pairing with pre-rRNA," Molecular and Cellular Biology, vol. 7, no. 8, pp. 2899-2913, 1987.

[21] T. S. Ro-Choi, "Nucleolar snoRNA and ribosome production," Molecules and Cells, vol. 7, no. 4, pp. 451-467, 1997.

[22] A. Krol, C. Branlant, E. Lazar, H. Gallinaro, and M. Jacob, "Primary and secondary structures of chicken, rat and man nuclear U4 RNAs. Homologies with U1 and U5 RNAs," Nucleic Acids Research, vol. 9, no. 12, pp. 2699-2716, 1981.

[23] S. Liu, P. Li, O. Dybkov et al., "Binding of the human Prp31 Nop domain to a composite RNA-protein platform in U4 snRNP," Science, vol. 316, no. 5821, pp. 115-120, 2007.

[24] R. Reddy, D. Henning, and H. Busch, "The primary nucleotide sequence of U4 RNA," Journal of Biological Chemistry, vol. 256, no. 7, pp. 3532-3538, 1981.

[25] A. Krol, H. Gallinaro, E. Lazar et al., "The nuclear 5S RNAs from chicken, rat and man. U5 RNAs are encoded by multiple genes," Nucleic Acids Research, vol. 9, no. 4, pp. 769-787, 1981.

[26] R. Reddy and H. Busch, "U-snRNAs of nuclear RNPs," in The Cell Nucleus, H. Busch, Ed., vol. 8, chapter 7, pp. 261-306, Academic Press, New York, NY, USA, 1981.

[27] G. R. Kunkel, R. L. Maser, J. P. Calvet, and T. Pederson, "U6 small nuclear RNA is transcribed by RNA polymerase III," Proceedings of the National Academy of Sciences of the United States of America, vol. 83, no. 22, pp. 8575-8579, 1986.

[28] P. Epstein, R. Reddy, D. Henning, and H. Busch, "The nucleotide sequence of nuclear U6 (4.7 S) RNA," Journal of Biological Chemistry, vol. 255, no. 18, pp. 8901-8906, 1980.

[29] K. L. Mowry and J. A. Steitz, "Identification of the human U7 snRNP as one of several factors involved in the 3' end maturation of histone premessenger RNA's," Science, vol. 238, no. 4834, pp. 1682-1687, 1987.

[30] K. Tyc and J. A. Steitz, "U3, U8 and U13 comprise a new class of mammalian snRNPs localized in the cell nucleolus," EMBO Journal, vol. 8, no. 10, pp. 3113-3119, 1989.

[31] T. S. Ro, M. Muramatsu, and H. Busch, "Labeling of RNA of isolated nucleoli with UTP- $2-{ }^{14} \mathrm{C}$," Biochemical and Biophysical Research Communications, vol. 14, no. 2, pp. 149-155, 1964.

[32] Y. C. Choi, K. Smetana, and H. Busch, "Studies on RNA isolated from nucleolar fractions of Novikoff hepatoma cells by sequential extractions with dilute and concentrated salt solutions," Experimental Cell Research, vol. 53, no. 2-3, pp. 582-602, 1968.
[33] E. S. Maxwell and M. J. Fournier, "The small nucleolar RNAs," Annual Review of Biochemistry, vol. 64, pp. 897-934, 1995.

[34] K. T. Tycowski, N.G. Kolev, N. K. Conrad, V. Fok, and J. A. Steitz, "The ever-growing world of small nuclear ribonucleoproteins," in The RNA World, R. F. Gesteland, T. R. Cech, and J. F. Atkins, Eds., chapter 12, pp. 327-368, CSHL Press, 2006.

[35] C. L. Will and R. Lührmann, "Spliceosome structure and function," in The RNA World, R. F. Gesteland, T. R. Cech, and J. F. Atkins, Eds., chapter 13, pp. 369-400, CSHL Press, 2006.

[36] T. S. Ro-Choi, R. Reddy, Y. C. Choi, N. B. Raj, and D. Henning, "Primary sequence of U1 nuclear RNA and unusual feature of 5' end structure of LMWN RNA," Proceedings Federation of American Societies for Experimental Biology, vol. 33, p. 1548, 1974.

[37] T. S. Ro-Choi, "Nuclear snRNA and nuclear function (discovery of 5' cap structures in RNA)," Critical Reviews in Eukaryotic Gene Expression, vol. 9, no. 2, pp. 107-158, 1999.

[38] T. S. Ro-Choi, Y. Moriyama, Y. C. Choi, and H. Busch, "Isolation and purification of a nuclear $4.5 \mathrm{~S}$ ribonucleic acid of the Novikoff hepatoma," Journal of Biological Chemistry, vol. 245, no. 8, pp. 1970-1977, 1970.

[39] S. M. el-Khatib, T. S. Ro-Choi, Y. C. Choi, and H. Busch, "Studies on nuclear 4.5 S ribonucleic acid III of Novikoff hepatoma ascites cells," Journal of Biological Chemistry, vol. 245, no. 13, pp. 3416-3421, 1970.

[40] G. Dreyfuss, M. J. Matunis, S. Piñol-Roma, and C. G. Burd, "hnRNP proteins and the biogenesis of mRNA," Annual Review of Biochemistry, vol. 62, pp. 289-321, 1993.

[41] J. C. Long and J. F. Caceres, "The SR protein family of splicing factors: master regulators of gene expression," Biochemical Journal, vol. 417, no. 1, pp. 15-27, 2009.

[42] G. Dreyfuss, "Structure and function of nuclear and cytoplasmic ribonucleoprotein particles," Annual Review of Cell Biology, vol. 2, pp. 459-498, 1986.

[43] W. M. LeStourgeon, S. F. Barnett, and S. J. Northington, "Tetramer of core proteins of $40 \mathrm{~S}$ nuclear ribonucleoprotein particles assemble to package nascent transcripts into a repeating array of regular particles," in The Eukaryotic Nucleus, P. R. Strauss and S. H. Willson, Eds., vol. 2, pp. 477-502, The Telford Press, NJ, USA, 1990.

[44] M. Zuker, "Computer prediction of RNA structure," in Methods in Enzymology, vol. 180, chapter 20, pp. 262-288, 1989.

[45] D. E. Draper, "Protein-RNA recognition," Annual Review of Biochemistry, vol. 64, pp. 593-620, 1995.

[46] H.-J. Kim and K. Han, "Automated modeling of the RNA folding process," Molecules and Cells, vol. 5, pp. 406-412, 1995.

[47] T. S. Ro-Choi and Y. C. Choi, "Thermodynamic analyses of the constitutive splicing pathway for ovomucoid pre-mRNA," Molecules and Cells, vol. 27, no. 6, pp. 657-665, 2009.

[48] T. S. Ro-Choi and Y. C. Choi, "Structural elements of dynamic RNA strings," Molecules and Cells, vol. 16, no. 2, pp. 201-210, 2003.

[49] T. S. Ro-Choi and Y. C. Choi, "A modeling study of Cotranscriptional metabolism of hnRNP using FMR1 Gene," Molecules and Cells, vol. 23, no. 2, pp. 228-238, 2007.

[50] J. S. Mattick, "The functional genomics of noncoding RNA," Science, vol. 309, no. 5740, pp. 1527-1528, 2005.

[51] J. M. Claverie, "Fewer genes, more noncoding RNA," Science, vol. 309, no. 5740, pp. 1529-1530, 2005. 
[52] U. A. Ørom, T. Derrien, M. Beringer et al., "Long noncoding RNAs with enhancer-like function in human cells," Cell, vol. 143, no. 1, pp. 46-58, 2010.

[53] W. J. Steele, N. Okamura, and H. Busch, "Effects of thioacetamide on the composition and biosynthesis of nucleolar and nuclear ribonucleic acid in rat liver," Journal of Biological Chemistry, vol. 240, pp. 1742-1749, 1965.

[54] R. W. Holley, G. A. Everett, J. T. Madison, and A. Zamir, "Nucleotide sequence in the yeast alanine transfer ribonucleic acid," Journal of Biological Chemistry, vol. 240, pp. 2122-2128, 1965.

[55] R. de Wachter and W. Fiers, "Studies on the bacteriophage MS2. IV. The 3'-OH terminal undecanucleotide sequence of the viral RNA chain," Journal of Molecular Biology, vol. 30, no. 3, pp. 507-518, 1967.

[56] M. Silberklang, A. M. Gillum, and U. L. RajBhandary, “[3] Use of in Vitro ${ }^{32} \mathrm{P}$ labeling in the sequence analysis of nonradioactive tRNAs," Methods in Enzymology, vol. 59, no. C, pp. 58-109, 1979.

[57] W. Y. Li, R. Reddy, D. Henning, P. Epstein, and H. Busch, "Nucleotide sequence of 7 S RNA. Homology to Alu DNA and La 4.5 S RNA," Journal of Biological Chemistry, vol. 257, no. 9, pp. 5136-5142, 1982.

[58] T. S. Ro-Choi, "U3 RNA cap structure, $\mathrm{m}_{3}^{2,2,7} \mathrm{GpppAmp-}$ A(m)pApG, of Novikoff hepatoma cell," Molecules and Cells, vol. 6, no. 4, pp. 436-443, 1996.

[59] P. Carninci and Y. Hayashizaki, "High-efficiency full-length cDNA cloning," Methods in Enzymology, vol. 303, pp. 19-44, 1999.

[60] D. A. Peattie, "Direct chemical method for sequencing RNA," Proceedings of the National Academy of Sciences of the United States of America, vol. 76, no. 4, pp. 1760-1764, 1979.

[61] Y. Kuchino and S. Nishimura, "Enzymatic RNA sequencing," Methods in Enzymology, vol. 180, pp. 154-163, 1989.

[62] B. G. Barrel, "Fractionation and sequence analysis of radioactive nucleotides," Procedures in Nucleic Acid Research, vol. 2, pp. 751-779, 1971.

[63] K. Randerath, R. C. Gupta, and E. Randerath, " $\left[{ }^{3} \mathrm{H}\right]$ and $\left.{ }^{[32} \mathrm{P}\right]$ derivative methods for base composition and sequence analysis of RNA," Methods in Enzymology, vol. 65, no. C, pp. 638-680, 1971.

[64] Y. C. Choi and H. Busch, "Modified nucleotides in T1 RNase oligonucleotides of $18 \mathrm{~S}$ ribosomal RNA of the Novikoff hepatoma," Biochemistry, vol. 17, no. 13, pp. 2551-2560, 1978.

[65] International Human Genome Sequencing Consortium, "Initial sequencing and analysis of the human genome," Nature, vol. 409, no. 6838, pp. 860-921, 2001.

[66] J. Craig Venter, M. D. Adams, E. W. Myers et al., "The sequence of the human genome," Science, vol. 291, no. 5507, pp. 1304-1351, 2001.

[67] R. H. Waterston, K. Lindblad-Toh, E. Birney et al., "Initial sequencing and comparative analysis of the mouse genome," Nature, vol. 420, no. 6915, pp. 520-562, 2002.

[68] G. S. Wang and T. A. Cooper, "Splicing in disease: disruption of the splicing code and the decoding machinery," Nature Reviews Genetics, vol. 8, no. 10, pp. 749-761, 2007.

[69] K. J. Hertel, "Combinatorial control of exon recognition," Journal of Biological Chemistry, vol. 283, no. 3, pp. 12111215, 2008.

[70] S. Hausmann, S. Zheng, M. Costanzo et al., "Genetic and biochemical analysis of yeast and human cap trimethylguanosine synthase: functional overlap of 2,2,7-trimethylguanosine caps, small nuclear ribonucleoprotein components, PREmRNA splicing factors, and RNA decay pathways," Journal of Biological Chemistry, vol. 283, no. 46, pp. 31706-31718, 2008.

[71] P. Misra, C. Qi, S. Yu et al., "Interaction of PIMT with transcriptional coactivators CBP, p300, and PBP differential role in transcriptional regulation," Journal of Biological Chemistry, vol. 277, no. 22, pp. 20011-20019, 2002.

[72] J. Mouaikel, U. Narayanan, C. Verheggen et al., "Interaction between the small-nuclear-RNA cap hypermethylase and the spinal muscular atrophy protein, survival of motor neuron," EMBO Reports, vol. 4, no. 6, pp. 616-622, 2003.

[73] P. T. Gilham, "An addition reaction specific for uridine and guanosine nucleotides and its application to the modification of ribonuclease action," Journal of the American Chemical Society, vol. 84, no. 4, pp. 687-688, 1962.

[74] R. Naylor, N. W. Y. Ho, and P. T. Gilham, "Selective chemical modifications of uridine and pseudouridine in polynucleotides and their effect on the specificities of ribonuclease and phosphodiesterases," Journal of the American Chemical Society, vol. 87, no. 18, pp. 4209-4210, 1965.

[75] N. W. Y. Ho and P. T. Gilham, "Reaction of pseudou-ridine and inosine with $\mathrm{N}$-cyclohexyl- $\mathrm{N}^{\prime}-\beta$-(4-methylmorpholinium) ethylcarbodiimide," Biochemistry, vol. 10, no. 20, pp. 3651-3657, 1971.

[76] A. G. Saponara and M. D. Enger, "Occurrence of N2,N2,7methylguanosine in minor RNA species of a mammalian cell line," Nature, vol. 223, no. 5213, pp. 1365-1366, 1969.

[77] T. S. Ro-Choi, R. Redy, D. Henning, T. Takano, C. W. Taylor, and H. Busch, "Nucleotide sequence of $4.5 \mathrm{~S}$ Ribonucleic Acid I of Novikoff hepatoma cell nuclei," Journal of Biological Chemistry, vol. 247, no. 10, pp. 3205-3222, 1972.

[78] S. Schwartz, N. Gal-Mark, N. Kfir, R. Oren, E. Kim, and G. Ast, "Alu exonization events reveal features required for precise recognition of exons by the splicing machinery," PLoS Computational Biology, vol. 5, no. 3, Article ID e1000300, 2009.

[79] K. Nagai, C. Oubridge, A. Kuglstatter, E. Menichelli, C. Isel, and L. Jovine, "Structure, function and evolution of the signal recognition particle," EMBO Journal, vol. 22, no. 14, pp. 3479-3485, 2003.

[80] A. W. Prestayko, M. Tonato, B. C. Lewis, and H. Busch, "Heterogeneity of nucleolar U3 ribonucleic acid of the Novikoff hepatoma," Journal of Biological Chemistry, vol. 246, no. 1, pp. 182-187, 1971.

[81] E. Randerath, C. T. Yu, and K. Randerath, "Base analysis of ribopolynucleotides by chemical tritium labeling: a methodological study with model nucleosides and purified tRNA species," Analytical Biochemistry, vol. 48, no. 1, pp. 172-198, 1972.

[82] R. Reddy, T. S. Ro-Choi, D. Henning, H. Shibata, Y. C. Choi, and H. Busch, "Modified nucleosides of nuclear and nucleolar low molecular weight ribonucleic acid," Journal of Biological Chemistry, vol. 247, no. 22, pp. 7245-7250, 1972.

[83] C. M. Mauritzen, Y. C. Choi, and H. Busch, "Preparation of Macromolecules of Very High Specific Activity of Tumor cells," in Methods in Cancer Research, H. Busch, Ed., vol. 6, pp. 253-282, Academic Press, New York, NY, USA, 1970.

[84] Y. C. Choi and T. S. Ro-Choi, "Basic characteristics of different classes of cellular RNAs; a directory," in Cell Biology; A Comprehensive Treatise, L. Goldstein and D. Prescott, Eds., vol. 3, chapter 12, pp. 609-667, New York Academic, New York, NY, USA, 1980. 
[85] H. Miyoshi, D. S. Dwyer, B. D. Keiper, M. Jankowska-Anyszka, E. Darzynkiewicz, and R. E. Rhoads, "Discrimination between mono- and trimethylated cap structures by two isoforms of Caenorhabditis elegans eIF4E," EMBO Journal, vol. 21, no. 17, pp. 4680-4690, 2002.

[86] C. Mazza, M. Ohno, A. Segref, I. W. Mattaj, and S. Cusack, "Crystal structure of the human nuclear cap binding complex," Molecular Cell, vol. 8, no. 2, pp. 383-396, 2001.

[87] C. Mazza, A. Segref, I. W. Mattaj, and S. Cusack, "Large-scale induced fit recognition of an $\mathrm{m}^{7} \mathrm{GpppG}$ cap analogue by the human nuclear cap-binding complex," EMBO Journal, vol. 21, no. 20, pp. 5548-5557, 2002.

[88] C. M. Smith and J. A. Steitz, "Sno storm in the nucleolus: new roles for myriad small RNPs," Cell, vol. 89, no. 5, pp. 669-672, 1997.

[89] C. Y. Lee, A. Lee, and G. Chanfreau, "The roles of endonucleolytic cleavage and exonucleolytic digestion in the $5^{\prime}$-end processing of S. cerevisiae box C/D snoRNAs," RNA, vol. 9, no. 11, pp. 1362-1370, 2003.

[90] T. Monecke, A. Dickmanns, and R. Ficner, "Structural basis for $\mathrm{m}^{7} \mathrm{G}$-cap hypermethylation of small nuclear, small nucleolar and telomerase RNA by the dimethyltransferase TGS1," Nucleic Acids Research, vol. 37, no. 12, pp. 3865-3877, 2009.

[91] A. Strasser, A. Dickmanns, R. Lührmann, and R. Ficner, "Structural basis for $\mathrm{m}_{3} \mathrm{G}$-cap-mediated nuclear import of spliceosomal UsnRNPs by snurportin1," EMBO Journal, vol. 24, no. 13, pp. 2235-2243, 2005.

[92] J. L. Chen, M. A. Blasco, and C. W. Greider, "Secondary structure of vertebrate telomerase RNA," Cell, vol. 100, no. 5, pp. 503-514, 2000.

[93] J. Franke, J. Gehlen, and A. E. Ehrenhofer-Murray, "Hypermethylation of yeast telomerase RNA by the snRNA and snoRNA methyltransferase Tgs1," Journal of Cell Science, vol. 121, no. 21, pp. 3553-3560, 2008.

[94] B. E. Jády, E. Bertrand, and T. Kiss, "Human telomerase RNA and box H/ACA scaRNAs share a common Cajal body-specific localization signal," Journal of Cell Biology, vol. 164, no. 5, pp. 647-652, 2004.

[95] S. Bektesh, K. Van Doren, and D. Hirsh, "Presence of the Caenorhabditis elegans spliced leader on different mRNAs and in different genera of nematodes," Genes \& Development, vol. 2, no. 10, pp. 1277-1283, 1988.

[96] T. Blumenthal, "Trans-splicing and operons," WormBook, pp. 1-9, 2005.

[97] C. K. Ho and S. Shuman, "Distinct roles for CTD Ser-2 and Ser-5 phosphorylation in the recruitment and allosteric activation of mammalian mRNA capping enzyme," Molecular Cell, vol. 3, no. 3, pp. 405-411, 1999.

[98] K. Mizumoto and Y. Kaziro, "Messenger RNA capping enzymes from eukaryotic cells," Progress in Nucleic Acid Research and Molecular Biology, vol. 34, no. C, pp. 1-28, 1987.

[99] D. Testa and A. K. Banerjee, "Two methyltransferase activities in the purified virions of vesicular stomatitis virus," Journal of Virology, vol. 24, no. 3, pp. 786-793, 1977.

[100] A. J. Shatkin, "Capping of eucaryotic mRNAs," Cell, vol. 9, no. 4, pp. 645-653, 1976.

[101] S. R. Langberg and B. Moss, "Post-transcriptional modifications of mRNA. Purification and characterization of cap I and cap II RNA (nucleoside-2'-)-methyltransferases from HeLa cells," Journal of Biological Chemistry, vol. 256, no. 19, pp. 10054-10060, 1981.

[102] D. L. Spector, "Colocalization of U1 and U2 small nuclear RNPs by immunocytochemistry," Biology of the Cell, vol. 51, no. 1, pp. 109-112, 1984.
[103] G. Plessel, U. Fischer, and R. Luhrmann, " $m_{3}$ G cap hypermethylation of U1 small nuclear ribonucleoprotein (snRNP) in vitro: evidence that the U1 small nuclear RNA-(guanosine$\mathrm{N} 2$ )- methyltransferase is a non-snRNP cytoplasmic protein that requires a binding site on the Sm core domain," Molecular and Cellular Biology, vol. 14, no. 6, pp. 4160-4172, 1994.

[104] I. W. Mattaj, "Cap trimethylation of U snRNA is cytoplasmic and dependent on U snRNP protein binding," Cell, vol. 46, no. 6, pp. 905-911, 1986.

[105] C. Verheggen, D. L. J. Lafontaine, D. Samarsky et al., "Mammalian and yeast U3 snoRNPs are matured in specific and related nuclear compartments," EMBO Journal, vol. 21, no. 11, pp. 2736-2745, 2002.

[106] J. Mouaikel, C. Verheggen, E. Bertrand, J. Tazi, and R. Bordonné, "Hypermethylation of the cap structure of both yeast snRNAs and snoRNAs requires a conserved methyltransferase that is localized to the nucleolus," Molecular Cell, vol. 9, no. 4, pp. 891-901, 2002.

[107] S. J. Baserga, M. Gilmore-Hebert, and X. W. Yang, "Distinct molecular signals for nuclear import of the nucleolar snRNA, U3," Genes and Development, vol. 6, no. 6, pp. 1120-1130, 1992.

[108] M. P. Terns and J. E. Dahlberg, "Retention and 5' cap trimethylation of U3 snRNA in the nucleus," Science, vol. 264, no. 5161, pp. 959-961, 1994.

[109] Y. Zhu, C. Qi, W. Q. Cao, A. V. Yeldandi, M. S. Rao, and J. K. Reddy, "Cloning and characterization of PIMT, a protein with a methyltransferase domain, which interacts with and enhances nuclear receptor coactivator PRIP function," Proceedings of the National Academy of Sciences of the United States of America, vol. 98, no. 18, pp. 10380-10385, 2001.

[110] C. Girard, C. Verheggen, H. Neel et al., "Characterization of a short isoform of human Tgs1 hypermethylase associating with small nucleolar ribonucleoprotein core proteins and produced by limited proteolytic processing," Journal of Biological Chemistry, vol. 283, no. 4, pp. 2060-2069, 2008.

[111] O. Komonyi, G. Pápai, I. Enunlu et al., "DTL, the Drosophila homolog of PIMT/Tgs1 nuclear receptor coactivatorinteracting protein/RNA methyltransferase, has an essential role in development," Journal of Biological Chemistry, vol. 280, no. 13, pp. 12397-12404, 2005.

[112] S. Hausmann and S. Shuman, "Specificity and mechanism of RNA cap guanine-N2 methyltransferase (Tgs1)," Journal of Biological Chemistry, vol. 280, no. 6, pp. 4021-4024, 2005.

[113] S. Hausmann and S. Shuman, "Giardia lamblia RNA cap guanine-N2 methyltransferase (Tgs2)," Journal of Biological Chemistry, vol. 280, no. 37, pp. 32101-32106, 2005.

[114] J. D. Bangs, P. F. Crain, T. Hashizume, J. A. McCloskey, and J. C. Boothroyd, "Mass spectrometry of mRNA cap 4 from trypanosomatids reveals two novel nucleosides," Journal of Biological Chemistry, vol. 267, no. 14, pp. 9805-9815, 1992.

[115] B. Mittra, J. R. Zamudio, J. M. Bujnicki et al., "The TbMTr1 spliced leader RNA cap 12 '-O-ribose methyltransferase from Trypanosoma brucei acts with substrate specificity," Journal of Biological Chemistry, vol. 283, no. 6, pp. 3161-3172, 2008.

[116] Y. Takagi, S. Sindkar, D. Ekonomidis, M. P. Hall, and C. K. Ho, "Trypanosoma brucei encodes a bifunctional capping enzyme essential for cap 4 formation on the spliced leader RNA," Journal of Biological Chemistry, vol. 282, no. 22, pp. 15995-16005, 2007.

[117] M. P. Hall and C. Kiong Ho, "Characterization of a Trypanosoma brucei RNA cap (guanine N-7) methyltransferase," RNA, vol. 12, no. 3, pp. 488-497, 2006. 
[118] E. Silva, E. Ullu, R. Kobayashi, and C. Tschudi, "Trypanosome capping enzymes display a novel two-domain structure," Molecular and Cellular Biology, vol. 18, no. 8, pp. 4612-4619, 1998.

[119] J. A. McCloskey, "Constituents of nucleic acids: overview and strategy," Methods in Enzymology, vol. 193, pp. 771-790, 1990.

[120] R. J. Taft, K. C. Pang, T. R. Mercer, M. Dinger, and J. S. Mattick, "Non-coding RNAs: regulators of disease," Journal of Pathology, vol. 220, no. 2, pp. 126-139, 2010. 

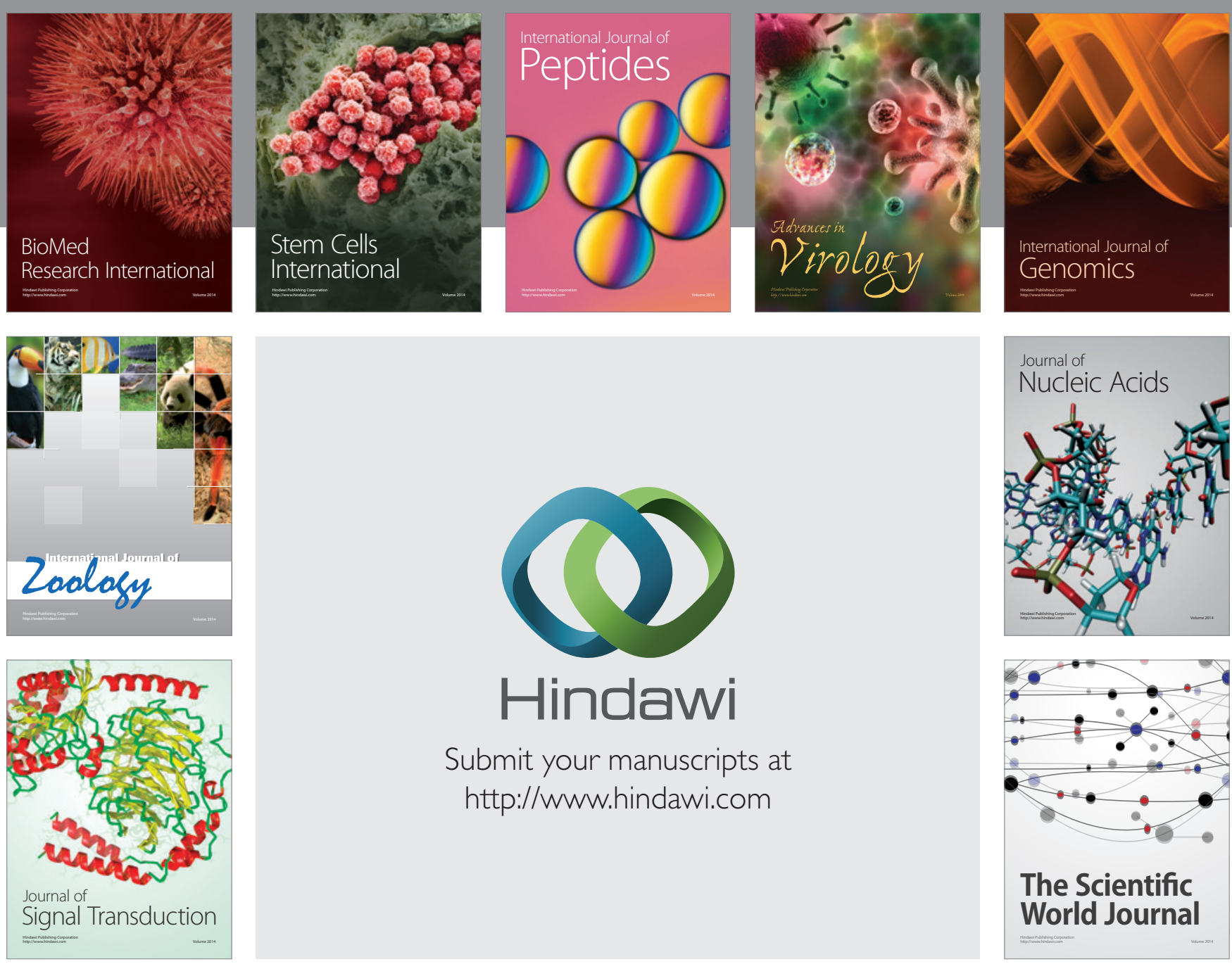

Submit your manuscripts at

http://www.hindawi.com
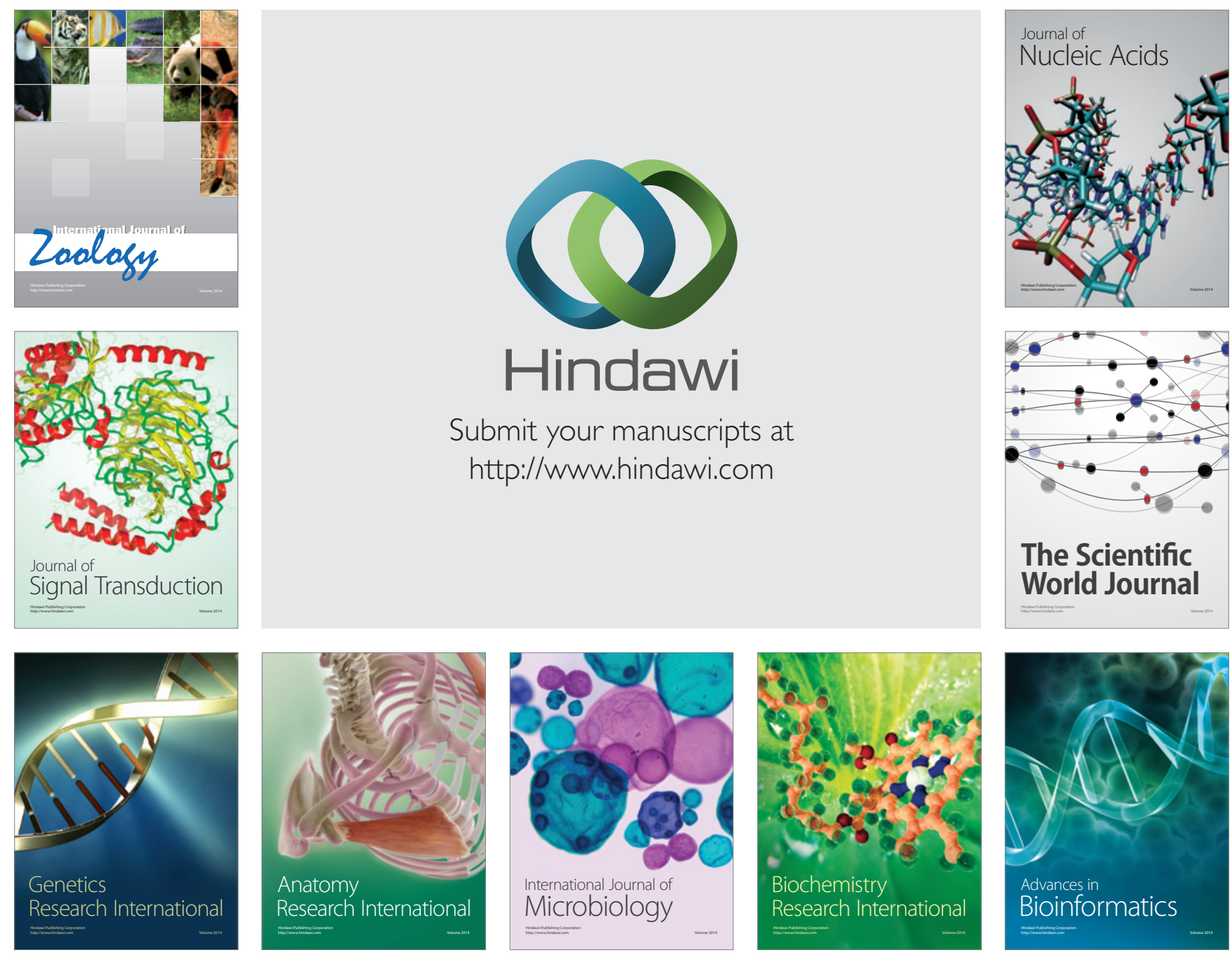

The Scientific World Journal
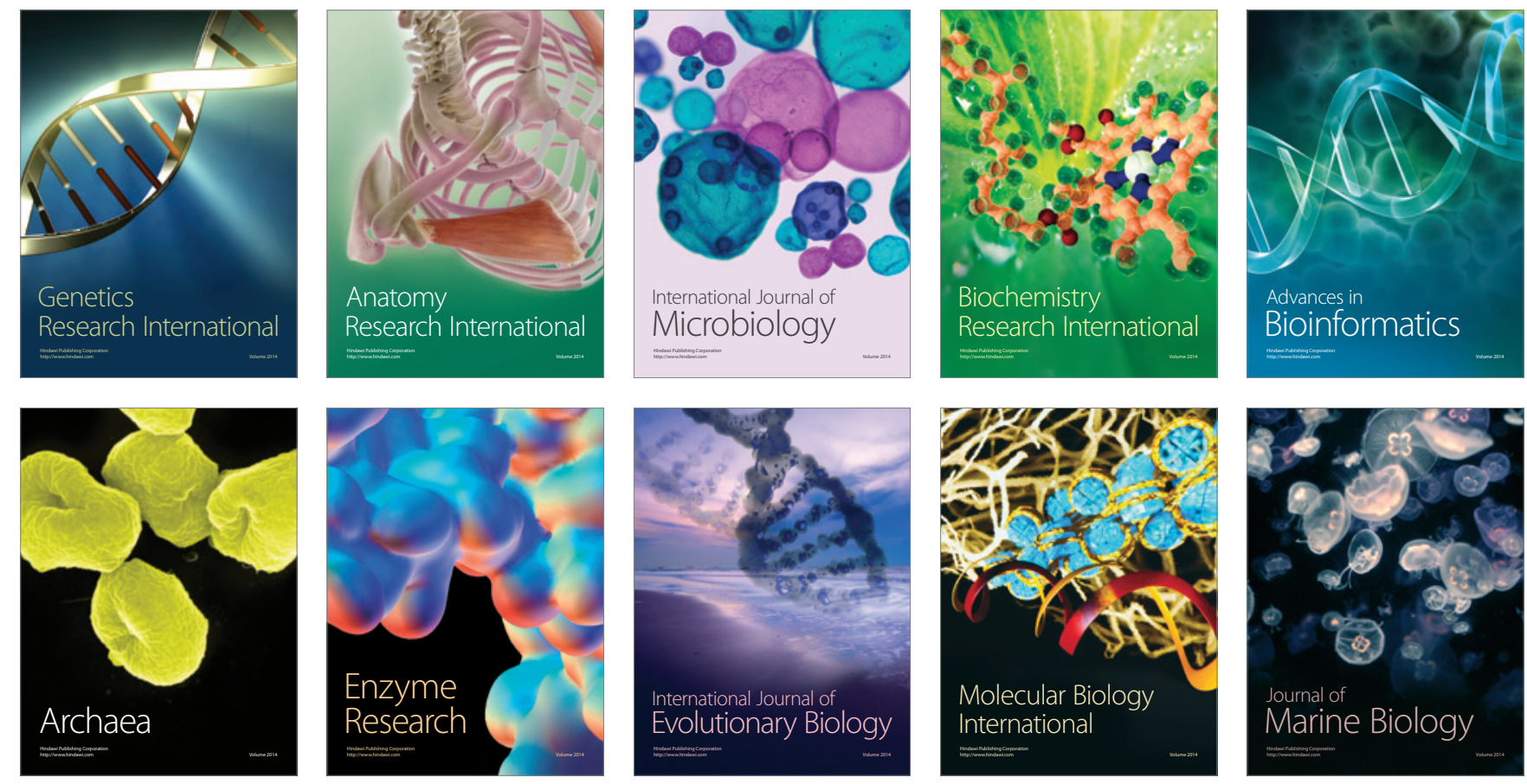